\title{
HYDROLOGIC DATA FOR THE WELDON SPRING CHEMICAL PLANT SITE AND VICINITY PROPERTY, ST. CHARLES COUNTY, MISSOURI--1986-89
}

By Michael J. Kleeschulte and Pierce W. Cross

U.S. GEOLOGICAL SURVEY

Open-File Report 90-552

Prepared in cooperation with the

U.S. DEPARTMENT OF ENERGY

Rolla, Missouri

1990 


\section{U.S. DEPARTMENT OF THE INTERIOR}

\section{MANUEL LUJAN, JR., Secretary}

U.S. GEOLOGICAL SURVEY

Dallas L. Peck, Director

For additional information write to:

\section{District Chief}

U.S. Geological Survey 1400 Independence Road

Mail Stop 200

Rolla, Missouri 65401
Copies of this report can be purchased from:

U.S. Geological Survey Books and Open-File Reports Federal Center, Building 810

Box 25425

Denver, Colorado 80225 


\section{CONTENTS}

\section{Page}

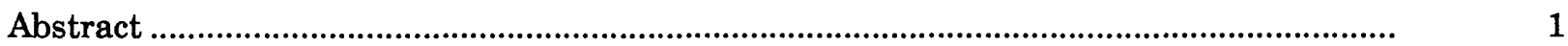

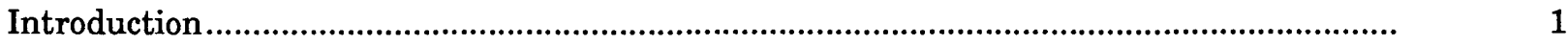

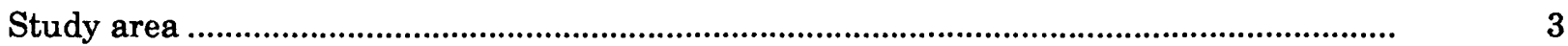

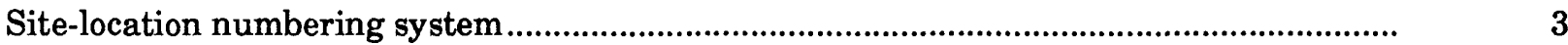

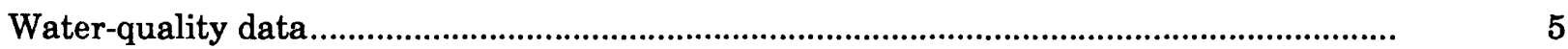

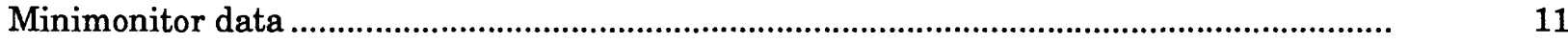

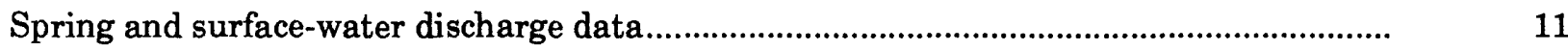

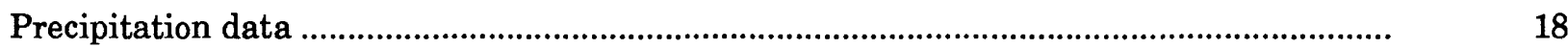

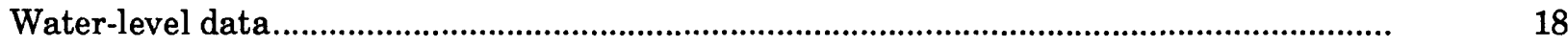

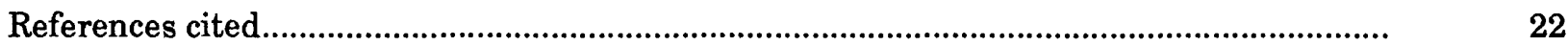




\section{ILLUSTRATIONS}

Figures 1.-7. Maps showing:

1. Location of the original U.S. Army property near Weldon Spring, Missouri.

2. Drainage-basin numbering system

3. Location of selected surface-water sites sampled at the Weldon Spring chemical plant site

4. Location of wells sampled at the Weldon Spring chemical plant site and vicinity property

5. Location of wells sampled at the Weldon Spring chemical plant site and vicinity property

6. Location of springs sampled on vicinity property near the Weldon Spring chemical plant site

7. Location of surface-water sites sampled on vicinity property near the Weldon Spring chemical plant site

Figures 8.-11. Graphs showing:

8. Daily mean specific conductance values for Burgermeister spring, July 2, 1987, through September 30, 1989.

9. Daily mean specific conductance values for Frog pond outflow, July 8, 1987, through September 30, 1989

10. Daily mean specific conductance values for Ash pond outflow, July 6, 1987, through September 30, 1989

11. Daily mean discharge at Burgermeister spring, May 1, 1986, through September 30, 1989

12. Daily mean discharge at unnamed tributary at Twin Island Lake, August 18, 1987, through September 30, 1989

13. Daily mean discharge at Schote Creek at U.S. Highways 40 and 61 , August 19, 1987, through September 30, 1989

Figure 14. Map showing location of wells used as water-level measurement sites at the Weldon Spring chemical plant site and vicinity property

15. Map showing location of wells used as water-level measurement sites at the Weldon Spring chemical plant site and vicinity property. 


\section{TABLES}

Table 1. Streamflow and water-quality data for selected surface-water sites at the Weldon Spring chemical plant site

2. Well and water-quality data for ground-water sites at the Weldon Spring chemical plant site and vicinity property.

3. Springflow and water-quality data for springs on vicinity property near the Weldon Spring chemical plant site

4. Streamflow and water-quality data for surface-water sites on vicinity property near the Weldon Spring chemical plant site.

5. Additional water-quality data for selected sites at the Weldon Spring chemical plant site and vicinity property

6. Daily mean specific conductance values for Burgermeister spring, July 1987 through September 1989

7. Daily mean specific conductance values for Frog pond outflow, July 1987 through September 1989

8. Daily mean specific conductance values for Ash pond outflow, July 1987 through September 1989

9. Daily mean discharge for Burgermeister spring, May 1986 through September 1989

10. Daily mean discharge for unnamed tributary at Twin Island Lake, August 1987 through September 1989

11. Daily mean discharge for Schote Creek at U.S. Highways 40 and 61, August 1987 through September 1989

12. Daily total precipitation values for the 4.6-square-mile area based on the isohyetal method, June 1987 through September 1989

13. Construction data for wells at the Weldon Spring chemical plant site and vicinity property.

14. Water-level data for wells at the Weldon Spring chemical plant site and vicinity property, May 1987 through August 1989 


\section{CONVERSION FACTORS AND VERTICAL DATUM}

Multiply

acre
mile
foot
inch
cubic foot
cubic foot per second
square mile
gallon
acre-foot

$\underline{B y}$

$$
0.4047
$$

1.609

0.3048

25.4

0.02832

0.02832

259.0

3.785
To obtain

hectare
kilometer
meter
millimeter
cubic meter
cubic meter per second
hectare
liter
cubic meter

Temperature in degrees Celsius $\left({ }^{\circ} \mathrm{C}\right)$ can be converted to degrees Fahrenheit $\left({ }^{\circ} \mathrm{F}\right)$ as follows:

$$
{ }^{\circ} \mathrm{F}=1.8^{\circ} \mathrm{C}+32
$$

Sea level: In this report "sea level" refers to the National Geodetic Vertical Datum of 1929 (NGVD of 1929)--a geodetic datum derived from a general adjustment of the first-order level nets of the United States and Canada, formerly called Sea Level Datum of 1929. 


\title{
HYDROLOGIC DATA FOR THE WELDON SPRING CHEMICAL PLANT SITE AND VICINITY PROPERTY, ST. CHARLES COUNTY, MISSOURI--1986-89
}

\author{
By \\ Michael J. Kleeschulte and Pierce W. Cross \\ ABSTRACT
}

\begin{abstract}
This report contains hydrologic data collected during an investigation of the Weldon Spring chemical plant site and vicinity property in St. Charles County, Missouri, from May 1986 through September 1989. The data consist of water-quality analyses of samples collected from 10 locations at the Weldon Spring chemical plant site. These sites were selected because they typically have increased concentrations of uranium. Water-quality analyses from 57 wells, 19 springs, and 17 surface-water sites also are included. This report also includes daily mean specific conductance values from July 1987 through September 1989 for Burgermeister spring, Frog pond outflow, and Ash pond outflow; daily mean discharges for Burgermeister spring from May 1986 through September 1989 and for the unnamed tributary containing Burgermeister spring at Twin Island Lake and for Schote Creek at U.S. Highways 40 and 61 from August 1987 through September 1989; daily values of total precipitation from June 1987 through September 1989; well-construction data; and water-level measurements from May 1987 through August 1989.
\end{abstract}

\section{INTRODUCTION}

A uranium processing plant was operated at the site of a former U.S. Army chemical plant near Weldon Spring in St. Charles County, Missouri, for the U.S. Atomic Energy Commission from 1957 to 1966 . Uranium ore concentrate and recycled scrap were converted to pure uranium trioxide, uranium tetrafluoride, and uranium metal (Weidner and Boback, 1982). Some thorium residues also were processed. Low-level radioactive wastes from the operation were pumped as a slurry to four raffinate pits near the plant that were excavated in glacial till between 1958 and 1964 (Lenhard and others, 1967). The wastes are presently (1990) being stored in these four pits, which have a combined surface area of about 26 acres. For the purpose of this report, the Weldon Spring chemical plant site refers to about 220 acres that contain the abandoned chemical plant and the raffinate pits area (fig. 1).

The U.S. Geological Survey began an initial Phase I study in 1983 to determine the extent and magnitude of surface- and ground-water contamination caused by the radioactive and associated wastes stored at the chemical plant. Data collected during this study confirmed that seepage from the raffinate pits had entered the ground-water system near the pits (Kleeschulte and Emmett, 1987). No contamination associated with the chemical plant or raffinate pits was detected in wells offsite; however, water from Burgermeister spring located 1.5 miles north of the site on the August A. Busch Memorial Wildlife Area contained concentrations of lithium, nitrate, and uranium that indicated that the spring receives recharge from sources possibly as far away as the Weldon Spring chemical plant site. The full extent of the areal and vertical contamination from the site was not completely determined at the end of the initial study.

During 1987, the U.S. Geological Survey started work on a Phase II study in the Weldon Spring area in cooperation with the U.S. Department of Energy. The primary objective of this study was to better define the extent and magnitude of contamination of the water resources in the vicinity of the 


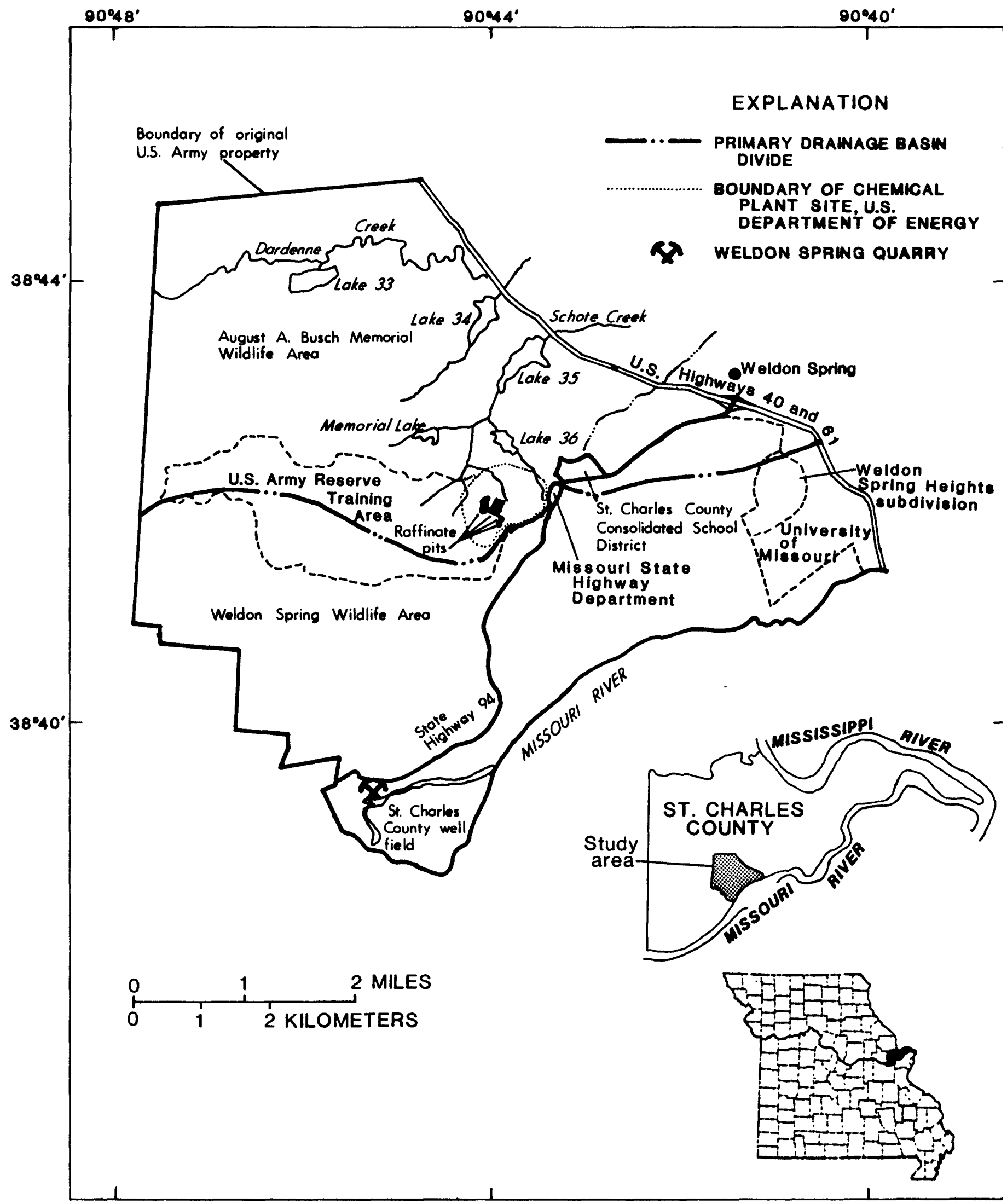

Figure 1.--Location of the original U.S. Army property near Weldon Spring, Missouri. 
Weldon Spring chemical plant site. Other objectives included determination of effects of climatic condition on surface- and ground-water systems and preparation of a ground-water flow model that included most of St. Charles County.

This report contains hydrologic data collected from May 1, 1986, through September 30, 1989, that will be used for the Phase II study. The report includes water-quality data from selected locations on the Weldon Spring chemical plant site, wells, springs, and surface-water bodies, such as streams and lakes; surface-water discharge data for Burgermeister spring, the unnamed tributary at Twin Island Lake, and Schote Creek at U.S. Highways 40 and 61; precipitation data; and water-level data for monitoring wells at the Weldon Spring chemical plant site and vicinity property.

\section{STUDY AREA}

The study area consists of about 280 square miles in St. Charles County in eastern Missouri; however, the area of more intensive data collection is on 17,232 acres near Weldon Spring, Missouri. This property was owned by the U.S. Department of the Army during World War II when it was the site of the Weldon Spring Ordnance Works. After the land was declared surplus in 1946, the ownership of all but 1,858 acres was transferred to other owners. Currently (1990) the U.S. Department of Energy owns 228 acres consisting of the abandoned chemical plant, raffinate pits, and the Weldon Spring quarry (Nelson, 1987). In this report, land on the original U.S. Army property that currently is not owned by the U.S. Department of Energy and not located at the chemical plant or raffinate pits areas is referred to as vicinity property.

The Weldon Spring chemical plant site is located on a ridge that is a surface-water divide for the Missouri and Mississippi River basins. The surface water draining north off the site flows into tributaries of Schote Creek, onto the August A. Busch Wildlife Area, then eventually into Dardenne Creek, which drains into the Mississippi River. The surface water draining to the south of the site flows into steep-gradient streams that drain directly into the Missouri River about 1.5 miles away.

The chemical-plant area is underlain by typically thin overburden deposits ranging from 0 to 55 feet thick. These deposits overlie a residuum layer ranging from 0 to 26 feet onsite; this residuum is characterized by cobbles and boulders of limestone and chert in a silty, sandy, clay matrix. These unconsolidated materials overlie the Keokuk and Burlington Limestones, which are cherty limestones that locally are fractured and contain solution channels. Springs, losing streams, solution cavities, and fractures exist both north and south of the Weldon Spring chemical plant site.

\section{SITE-LOCATION NUMBERING SYSTEM}

The site-location numbering system was developed by U.S. Department of Energy contractors and Missouri Department of Natural Resources personnel. This system uses a two-letter prefix to identify the type of feature. This is followed by four numbers that provide a unique location identifier. The prefixes are MW for monitoring wells, SP for springs, ST for streams, and SH for swallow holes. The first digit of the four-number unique location identifier, Xnnn, represents a general location. The $2000-4000$ series are numbers reserved for monitoring wells. The 2000 series wells are located in the chemical plant area, the 3000 series wells are located in the raffinate pits area, and the 4000 series wells are located on vicinity property. The $5000-6000$ series are used for non-monitoring well hydrologic features. The 5000 series indicates a location in the Missouri River basin to the south of the Weldon Spring chemical plant site and the 6000 series indicates a location in the Mississippi River basin to the north.

The second digit of the four-digit identifying number, $\mathrm{nXnn}$, represents a drainage basin. The numbering begins with the drainage basin at the east end of the original U.S. Army property and increases to the west (fig. 2). The zero hundreds series, n0nn, represents drainage basins out of the 


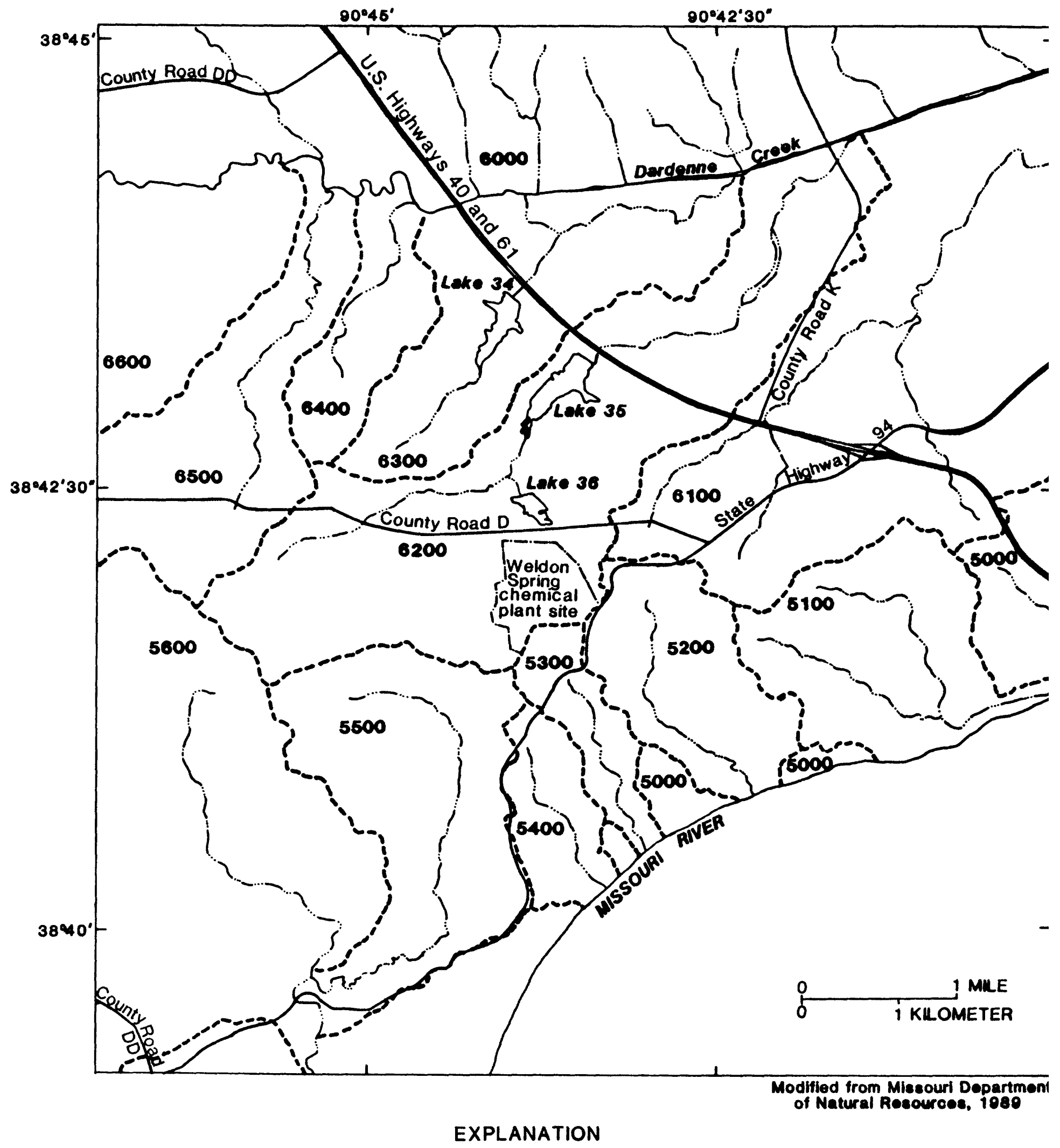

- - DRANAGE-BASIN BOUNDARY

5600 DRAINAGE-BASIN IDENTIFICATION NUMBER

Figure 2.--Drainage-basin numbering system. 
area of interest. The last two digits, nnXX, of the identifier are a sequential number assigned to the feature. This provides a unique identification label for each feature (Missouri Department of Natural Resources, 1989).

Two other well series are discussed in this report. The USGS wells were contracted by the U.S. Geological Survey and are on the August A. Busch Memorial Wildlife Area. The MWGS-series wells consist of two well clusters contracted by the U.S. Department of Energy for the U.S. Geological Survey and are on the vicinity property.

\section{WATER-QUALITY DATA}

Water-quality samples were collected from 10 selected surface-water locations at the Weldon Spring chemical plant site (fig. 3). These sites were selected because they typically have increased concentrations of uranium. Water-quality analyses from 57 wells, 19 springs, and 17 surface-water sites, including 3 surface-water impoundments, also are included. The purpose of this sampling was to determine locations where possible water contamination associated with the Weldon Spring chemical plant site has occurred. The offsite-sampling locations enclose the chemical plant site on all sides with the notable exception of the west side along the ridge where there are no springs and, until the summer of 1989 , there were no wells. The sampled sites extend northward to Dardenne Creek and to the south to the Missouri River. The location of the sampled sites is shown in figures 3 to 7.

Streamflow and water-quality data for selected surface-water sites at the Weldon Spring chemical plant site are listed in table 1 , at the back of this report. Well and water-quality data for ground-water sites at the Weldon Spring chemical plant site and vicinity property are listed in table 2, at the back of this report. Discharge and water-quality data for springs on vicinity property near the Weldon Spring chemical plant site are listed in table 3, at the back of this report. Streamflow and water-quality data for surface-water sites on vicinity property near the Weldon Spring site are listed in table 4, at the back of this report. The water-quality data include major inorganic constituents, nutrients, trace elements, organic compounds, and radiochemical analyses. More complete waterquality analyses were made for the sites listed in table 5, at the back of this report.

The water-quality samples collected from the USGS- and MWGS-series wells were obtained by using a submersible pump with a garden hose for a discharge line. The smaller diameter MW-series monitoring wells at the Weldon Spring chemical plant site were sampled using a $13 / 4$-inch diameter pneumatic pump. The water samples were collected after a minimum of one-pipe volume of water was removed from the well. Springs were sampled as near to the orifice as possible. Streams were sampled on or near shoals near the centroid of the flowing section. Water samples from impoundments were collected by submerging the sample bottles at a point about 5 feet from the bank.

All samples were analyzed by laboratories of the U.S. Geological Survey. Samples were analyzed for inorganic constituents according to methods described by Fishman and Friedman (1989), organic compounds according to methods described by Wershaw and others (1983), and radiochemical substances according to methods described by Thatcher and others (1977). Chemical constituents referred to as "dissolved" were determined from samples that were filtered at the time of sampling through 0.45 -micrometer membrane filters located between lucite plates, using a peristaltic pump as the pressure source.

Specific conductance, $\mathrm{pH}$, water temperature, alkalinity, oxidation-reduction potentials, dissolved-oxygen concentrations, and ferrous-iron concentrations were determined onsite. Several specific conductance, $\mathrm{pH}$, and alkalinity values are reported as laboratory values on various tables. When equipment problems occurred onsite making it difficult to get field measurements, or when anion-cation balances using the field alkalinity differed by more than 10 percent, the laboratory alkalinity value was used. On these occasions it is speculated problems with the $\mathrm{pH}$ meter occurred because of a defective probe, causing drifting of the measured $\mathrm{pH}$ value in the field. Specific 

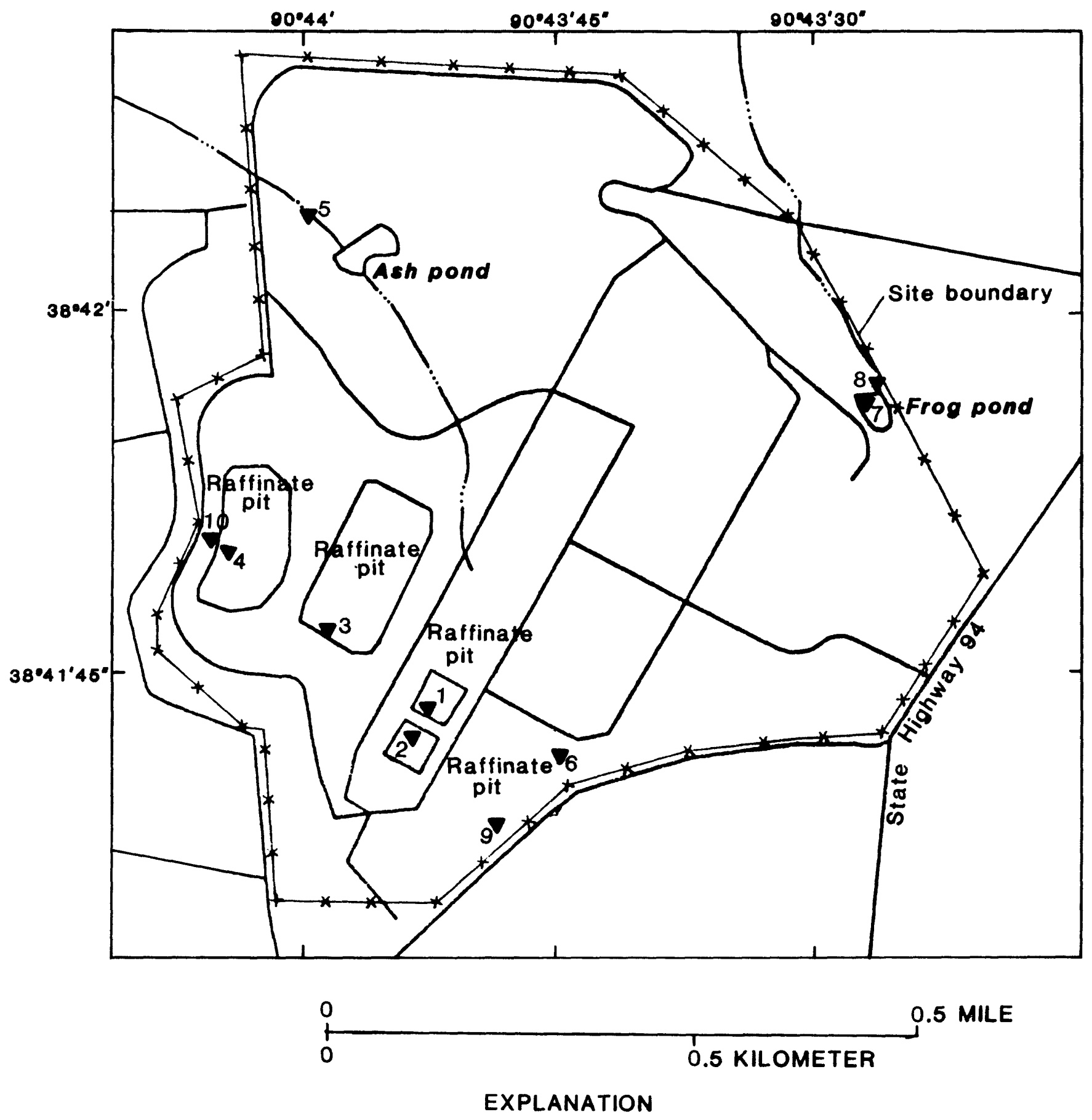

1 SURFACE-WATER SAMPLING SITE

NUMBER--8ite number roferenced

in table 1

Figure 3.--Location of selected surface-water sites sampled at the Weldon Spring chemical plant site. 


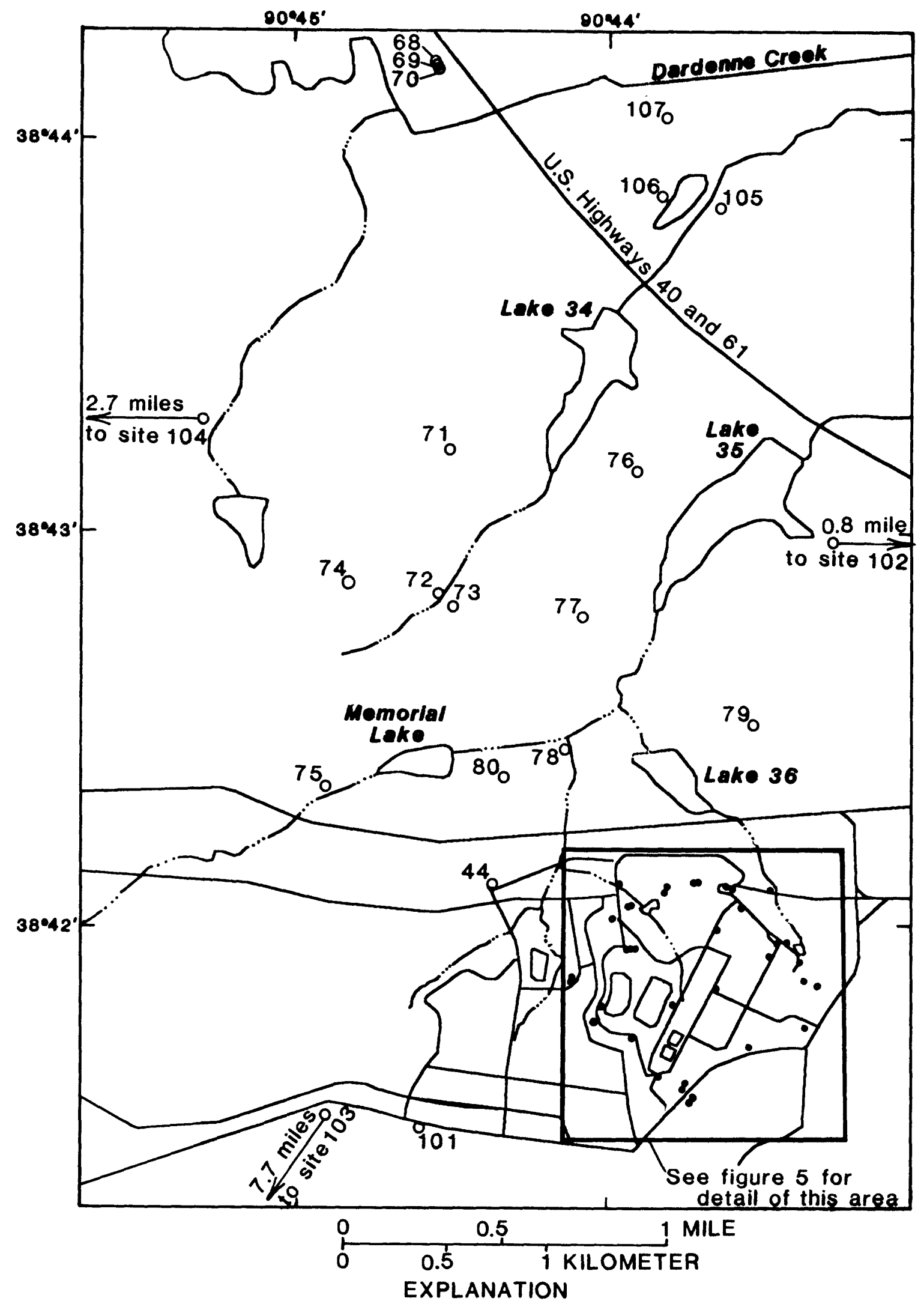

71 WELL AND WATER-QUALITY SITE NUMBER--SITE number roferenced in table 2

1030 WELL AND WATER-QUALITY SITE NUMBER--ExaCt location not on this map

Figure 4.--Location of wells sampled at the Weldon Spring chemical plant site and vicinity property. 

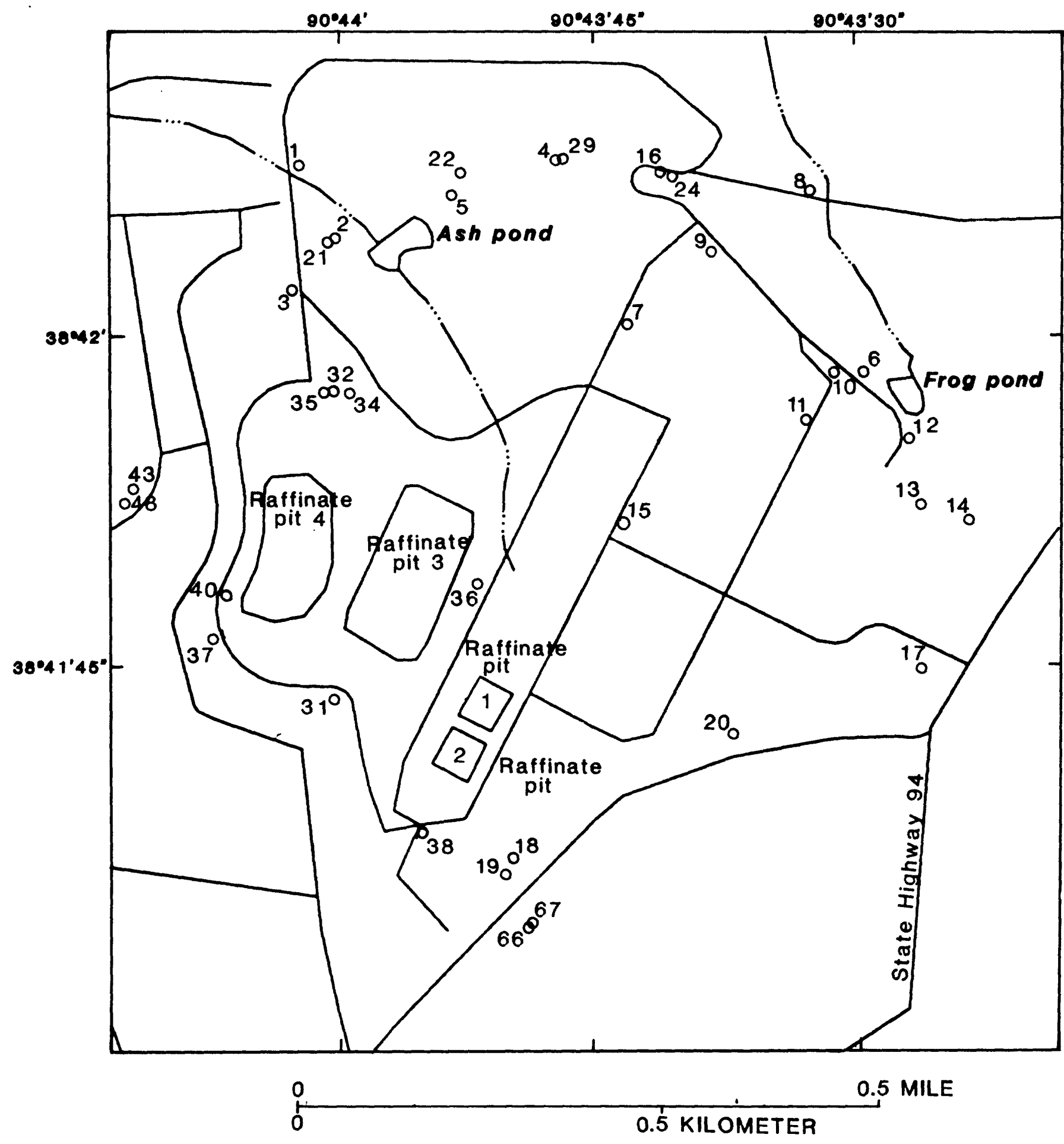

EXPLANATION

17. WELL AND WATER-QUALTYY BTTE MUMOER--SHE number referenced in table 2

Figure 5.--Location of wells sampled at the Weldon Spring chemical plant site and vicinity property. 

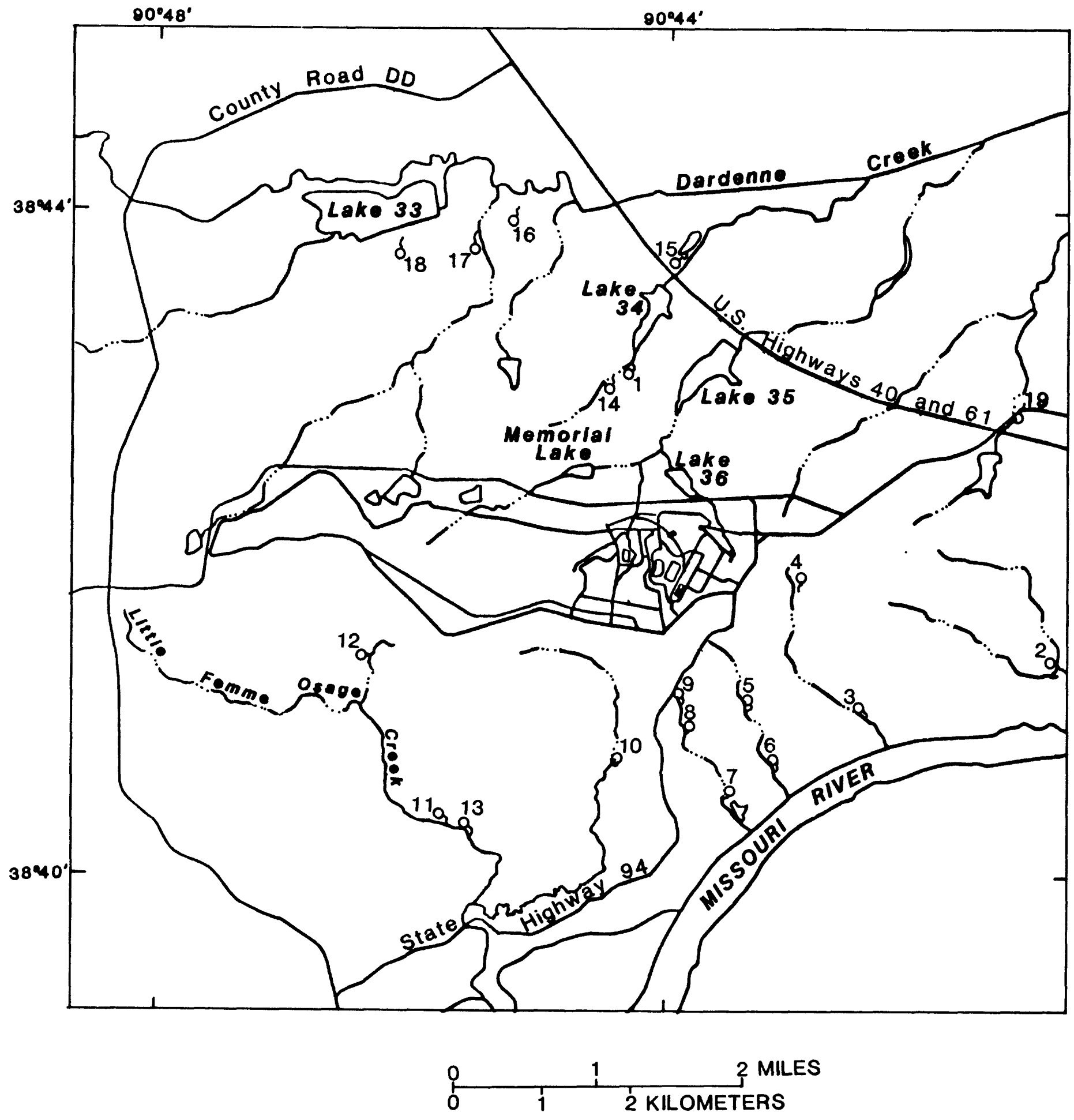

\section{EXPLANATION}

$\delta_{1}$ SPRING AND WATER-QUALITY SITE NUMBER--8ITE

Figure 6.-- Location of springs sampled on vicinity property near the Weldon Spring chemical plant site. 

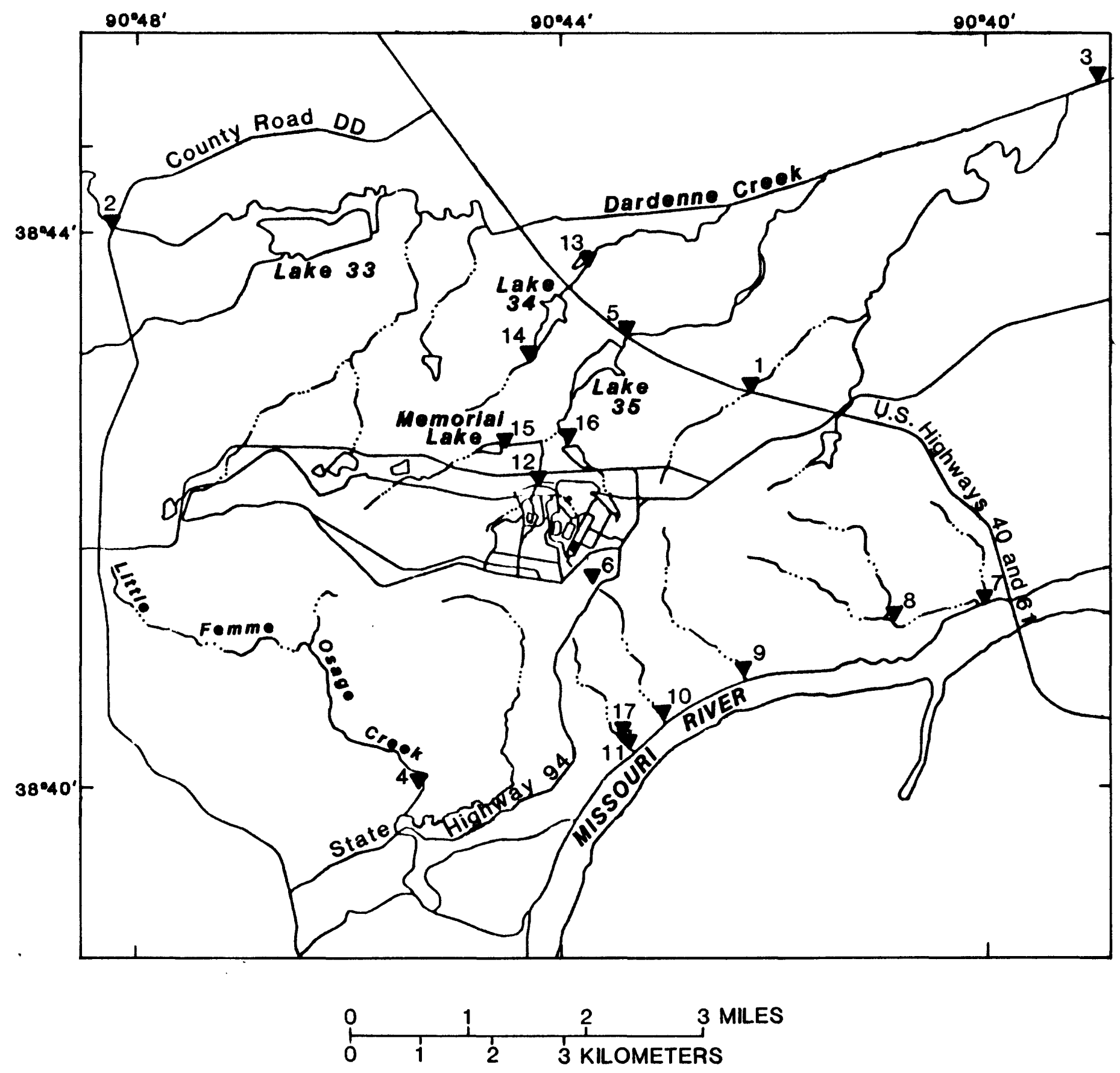

EXPLANATION

16

SURFACE-WATER SAMPLING SITE NUMBER--SIte number reforenced in tablo 4

Figure 7.--Location of surface-water sites sampled on vicinity property near the Weldon Spring chemical plant site. 
conductance values were measured using a portable conductivity meter with temperature compensation designed to express readings in microsiemens per centimeter at 25 degrees Celsius. The potentiometric method was used to measure both the $\mathrm{pH}$ value and alkalinity. Water temperature was measured with a mercury thermometer to the nearest 0.5 degree Celsius. Alkalinity was determined by incremental titration with 0.1600 normal sulfuric acid past the inflection point. Oxidation-reduction potentials were determined by measuring the voltage developed at the surface of a platinum electrode immersed in the water sample. Dissolved-oxygen concentrations were measured using a portable temperature compensated meter. Ferrous-iron concentrations were determined using the phenanthroline method. Values were measured by a portable spectrophotometer calibrated and set to the 510-nanometer wavelength.

\section{MINIMONITOR DATA}

In July 1987, minimonitors were installed at the orifice of Burgermeister spring, the outflow of Frog pond, and the outflow of Ash pond. These minimonitors recorded the specific conductance of the water continually at 30-minute intervals. Specific conductance measures the ability of a water to conduct an electrical current. Specific conductance is related to the type and concentration of ions in solution and can be used for approximating the dissolved-solids concentration of the water. The daily mean specific conductance values for Burgermeister spring are listed in table 6, at the back of this report, and are shown in figure 8. The daily mean specific conductance values for Frog pond outflow are listed in table 7 (at the back of this report) and are shown in figure 9. The daily mean specific conductance values for Ash pond outflow are listed in table 8 (at the back of this report) and are shown in figure 10. Specific conductance was measured to make gross estimates of the water-quality variation over time and during different climatic conditions at these three sites.

\section{SPRING AND SURFACE-WATER DISCHARGE DATA}

Daily mean discharge data collected at Burgermeister spring, the unnamed tributary at Twin Island Lake, and Schote Creek at U.S. Highways 40 and 61 are presented in tables 9-11 (at the back of this report) and the hydrographs for these sites are shown in figures 11 to 13 . Water from Burgermeister spring flows into an unnamed tributary of Dardenne Creek that is gaged at Twin Island Lake. Surface runoff from the chemical plant site that drains to the north flows into tributaries of Schote Creek. This discharge was gaged on the main stem of Schote Creek at U.S. Highways 40 and 61.

Water levels (stage) were continually recorded by digital recorders every 15 minutes at Burgermeister spring and Schote Creek. Stage was recorded every 5 minutes at the Twin Island Lake site because of the rapid response of this tributary to precipitation. A 90-degree sharp-crested V-notch weir was constructed across the Burgermeister spring branch channel. The stage-discharge relation for the spring was defined by the weir formula (Anderson, 1971):

$$
\mathrm{Q}=2.4381 \mathrm{H}^{5 / 2}
$$

where $Q$ is discharge of water, in cubic feet per second; and $H$ is head of water above the base of the notch, in feet. This stage-discharge relation was verified by occasional discharge measurements.

The stage-discharge relation for the Twin Island Lake and Schote Creek sites was developed by current-meter measurements made at varying stages; however, because of the rapid response of the unnamed tributary at Twin Island Lake and short duration of peak flow during storms, a gage height of 2.27 was the maximum stage at which a discharge measurement was made. During the period of record, 19 days had some part of the record exceeding the maximum measured discharge stage. The daily mean discharge for these days was computed by correlating the daily mean gage height with the corresponding discharge. On six of these days the daily mean discharge exceeded the maximum measured discharge stage. The known stage-discharge relation was extended linearly on a log-log 


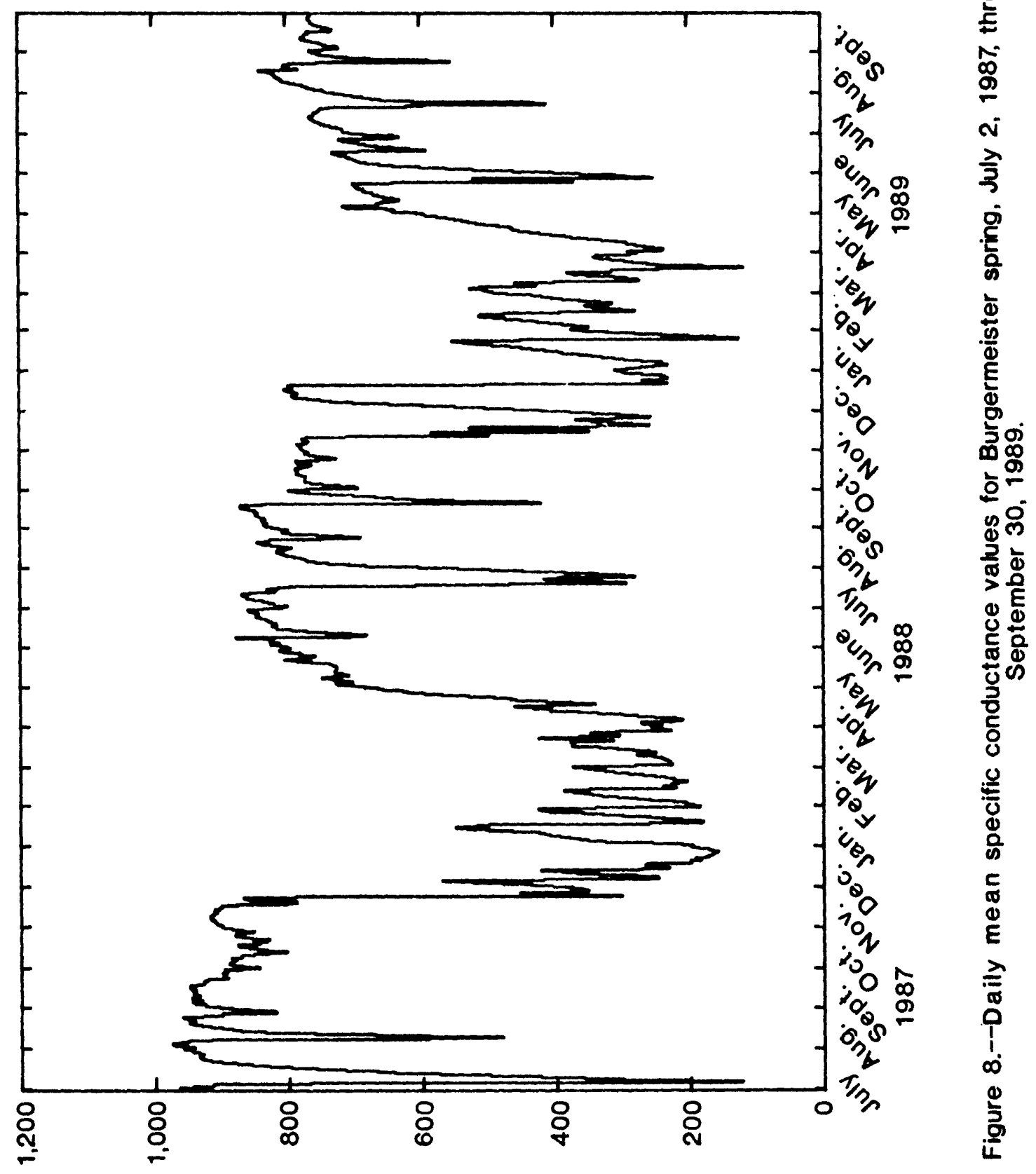

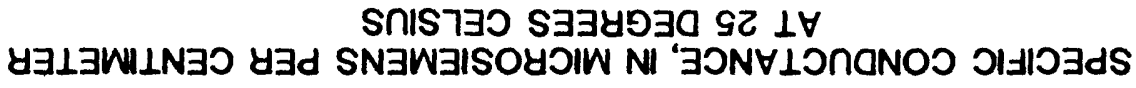




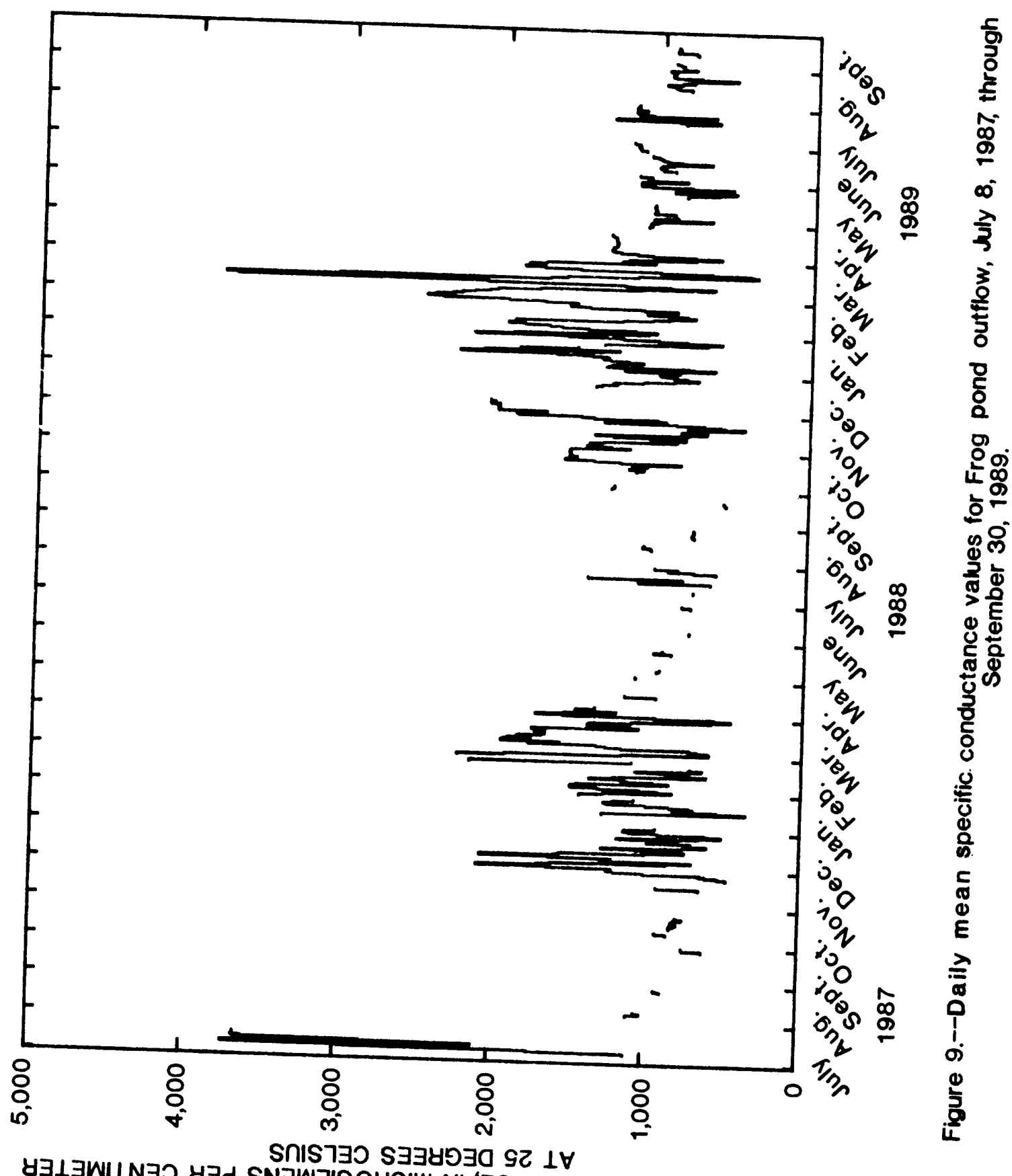

Y 


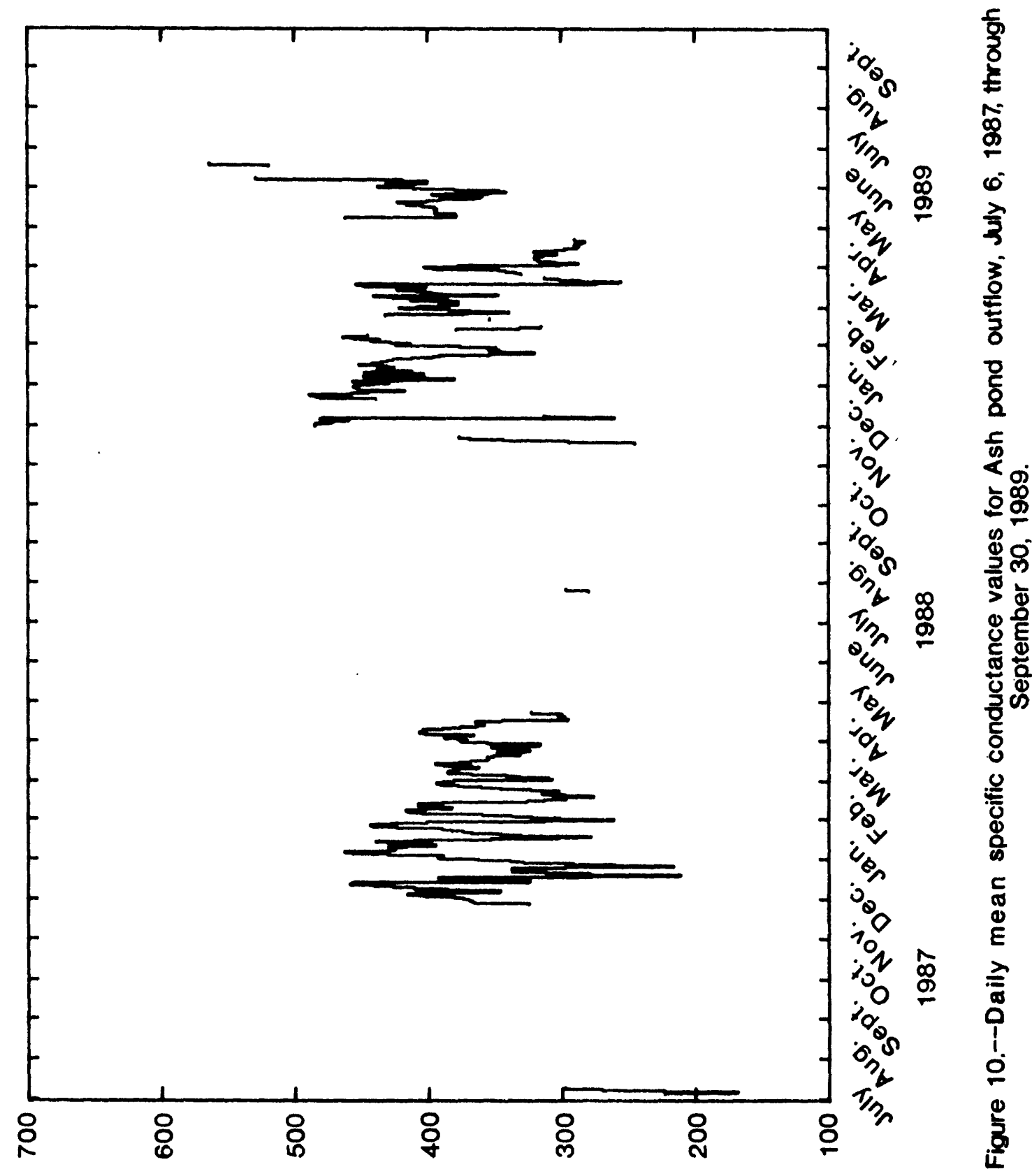

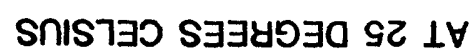

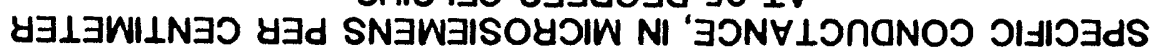




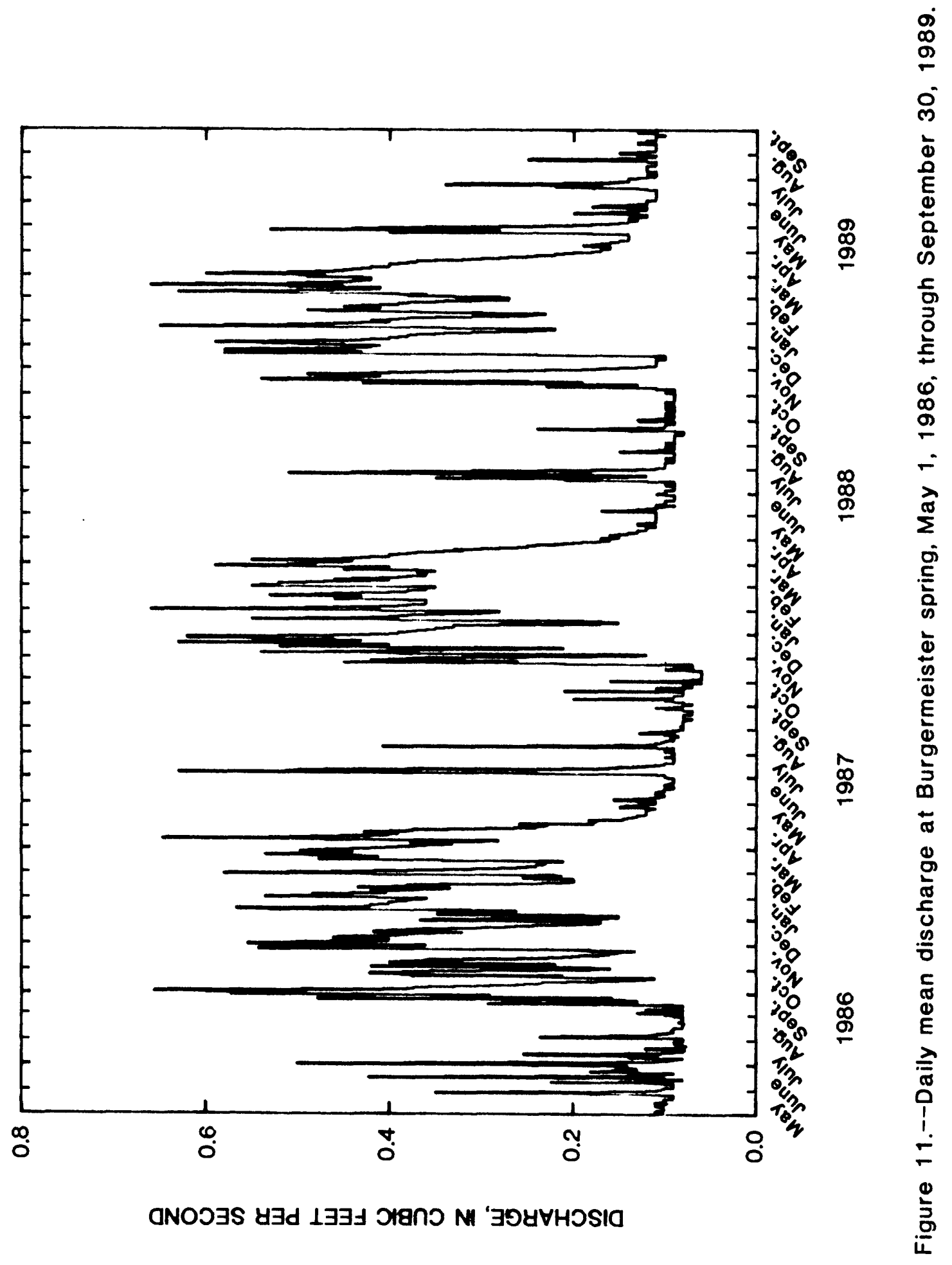




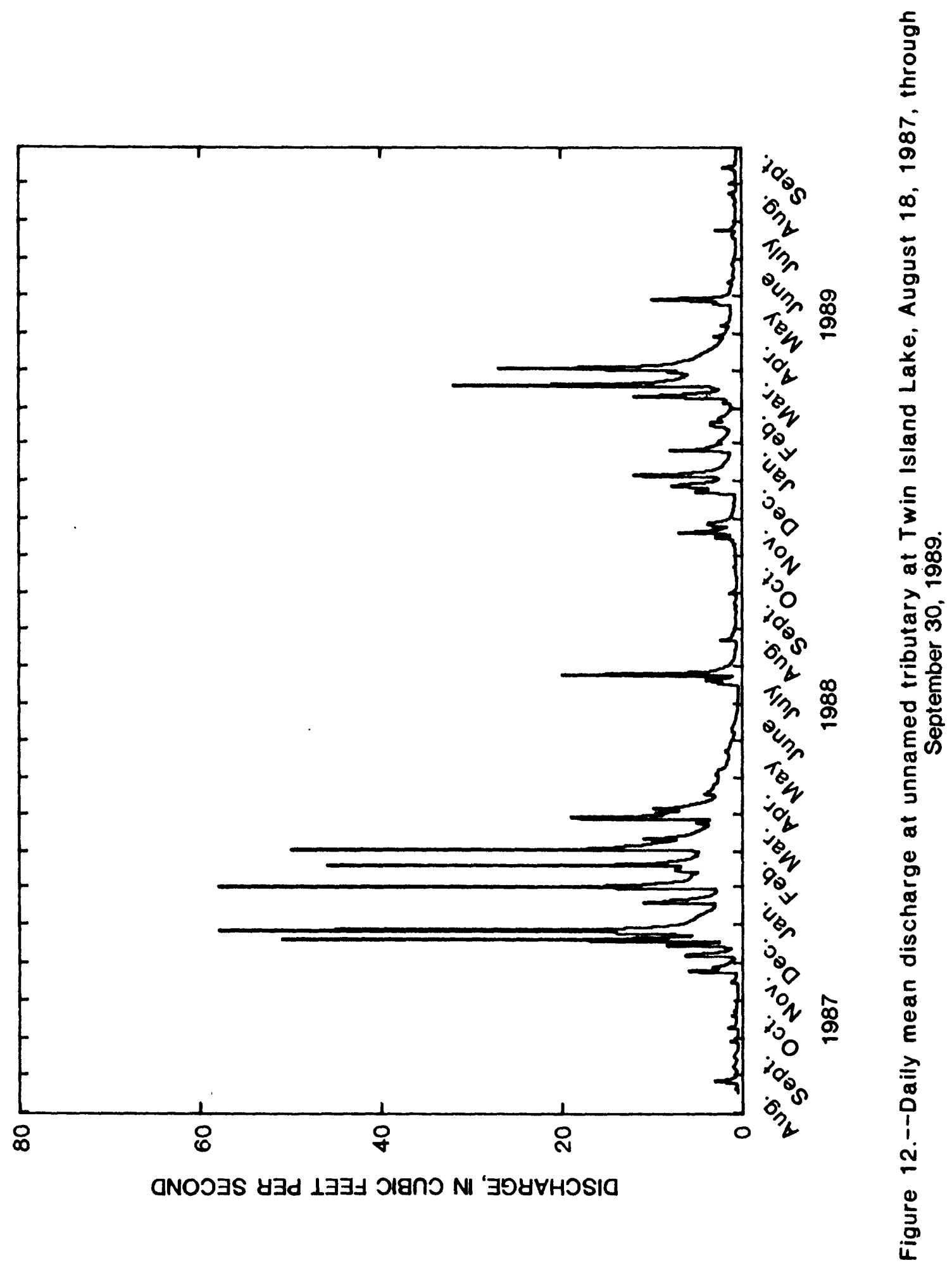




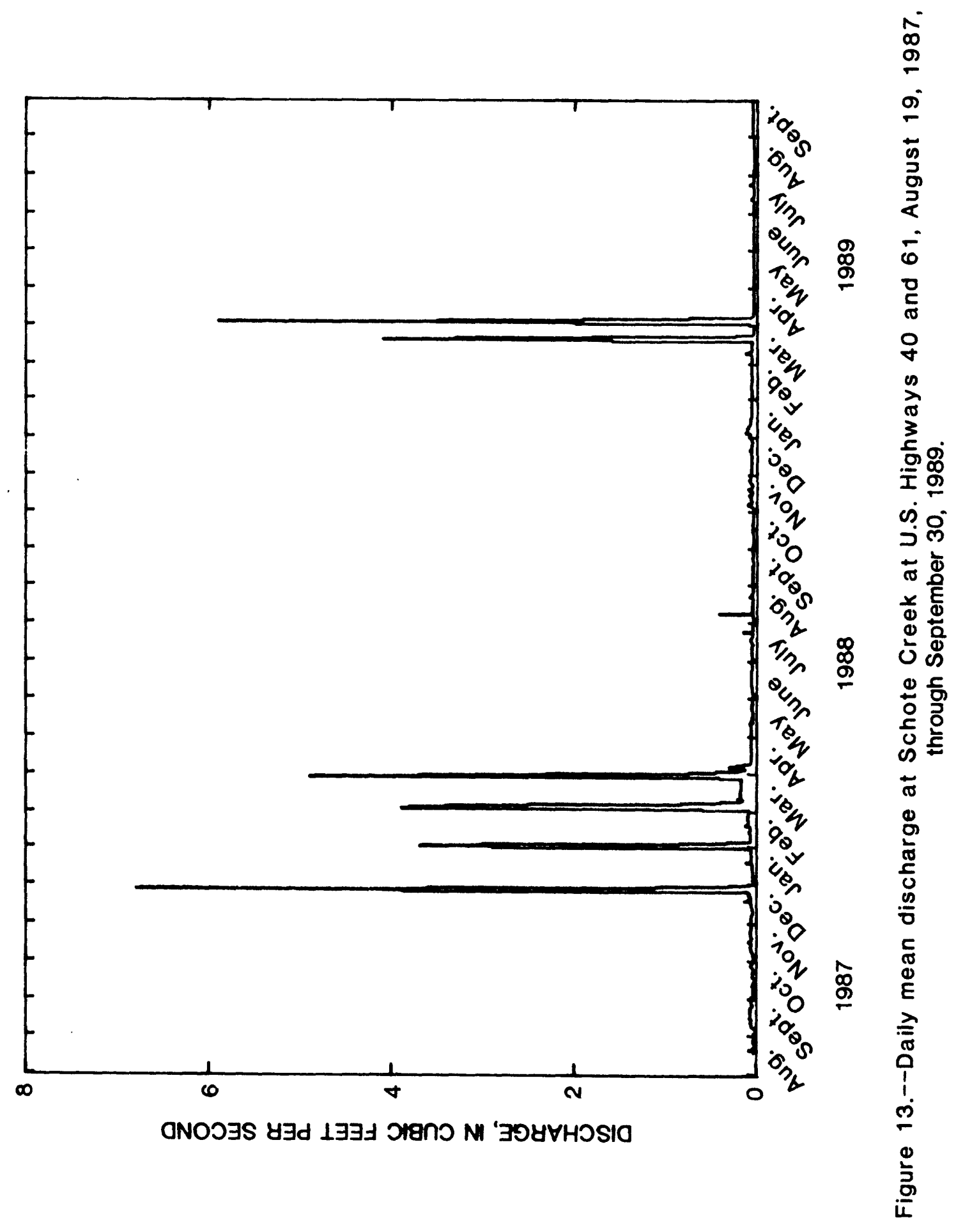


scale to obtain a daily discharge on these days. Schote Creek had a maximum measured discharge for a gage height of 0.99 foot. This gage height was exceeded on 19 days during the period of record and the daily mean gage height was greater than 0.99 foot on 13 of these days. The daily discharge on these days was computed using the same method as described for the unnamed tributary at Twin Island Lake.

When the stage-discharge relation changed because of a change in the physical features that form the control or changed temporarily because of aquatic growth or debris on the control, the daily mean discharge was computed by the shifting-control method. Using this method, correction factors based on individual discharge measurements were applied to the gage heights.

The accuracy of streamflow data depends on the stability of the stage-discharge relation, the frequency and distribution of discharge measurements throughout the rating curve, and the accuracy of observations of stage, measurements of discharge, and interpretations of records. The degree of accuracy of these records are defined as follows: "excellent" means that about 95 percent of the daily discharges are within 5 percent; "good", within 10 percent; and "fair", within 15 percent. "Poor" means that daily discharges have less than "fair" accuracy. The record for Burgermeister spring is rated good. The record for Twin Island Lake site is rated fair except for the periods of record January 2630, 1989; May 18-30, 1989; July 29 to August 15, 1989; and September 21-30, 1989, which are rated poor because of stream aggradation burying the intake of the gaging station and causing loss of gage height record. The daily discharge record on December 20, 1987; February 1 and 19, 1988; March 3, 1988; March 20, 1989; and April 3, 1989, is rated poor because the daily mean gage height exceeded the maximum measured gage height. The record for Schote Creek is rated fair except for the periods December 27-29, 1987; February 2, 1988; March 4-6, 1988; March 30-31, 1988; March 21-22, 1989; and April 4-5, 1989, which are rated poor because the daily mean gage height exceeded the maximum measured gage height.

\section{PRECIPITATION DATA}

In June 1987, 19 total-catch rain gages were installed in approximately a 4.6-square-mile area that included the drainage basins of the unnamed tributary on which Burgermeister spring is located and Schote Creek. These two basins were combined because the Weldon Spring chemical plant site is located in Schote Creek basin, but interbasin transfer of water occurs from Schote Creek to the unnamed tributary basin containing Burgermeister spring (Kleeschulte and Emmett, 1987). Because these two basins are hydrologically connected, they were considered together. Daily total precipitation for the 4.6-square-mile area was calculated using the isohyetal method; these values are reported in table 12, at the back of this report. As the study progressed, in October 1988 the decision was made that the number of rain gages could be decreased with minimal loss of accuracy and the number of gages was decreased to nine.

The gages were visited as needed after rainfall and total precipitation values were recorded. Daily precipitation values were calculated by prorating the calculated precipitation totals from the rain gages for a specific period of time with the daily precipitation values reported in Missouri Climatological Data monthly reports (National Oceanic and Atmospheric Administration, 1987-1989) for surrounding areas.

\section{WATER-LEVEL DATA}

Construction data for wells at the Weldon Spring chemical plant site and vicinity property are listed in table 13, at the back of this report. Altitude of land surface or height of measuring point elevations that are reported to the nearest foot were determined from topographic maps. The source of the reported data is listed as a footnote after the well name. However, if data for one well were obtained from more than one source, the second source is noted after the corresponding item. The U.S. Department of Army had installed several well clusters to the west of the Weldon Spring chemical 


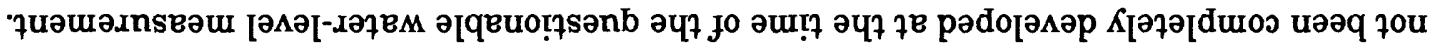

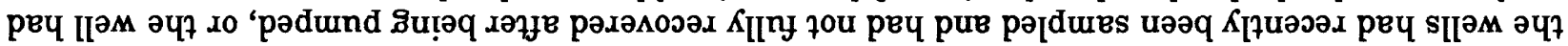

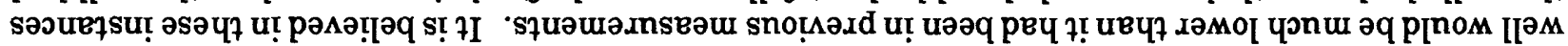

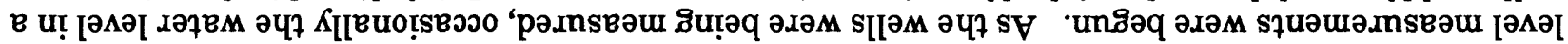

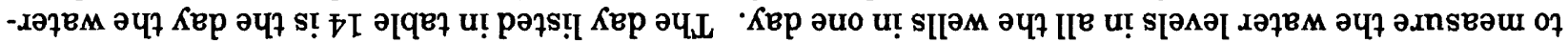

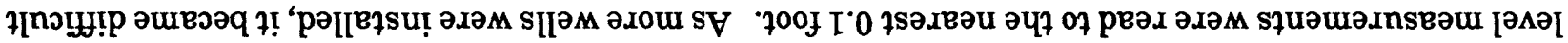

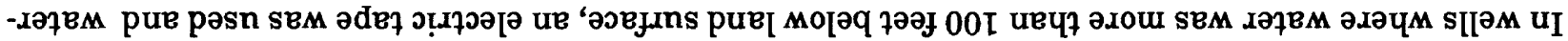

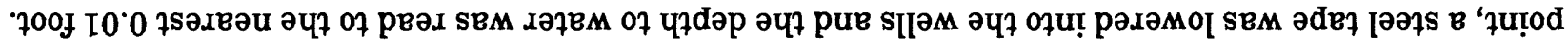

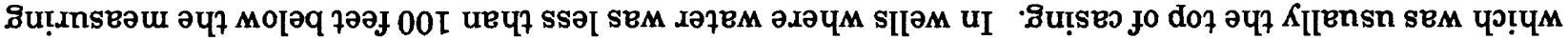

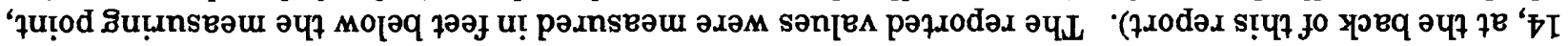

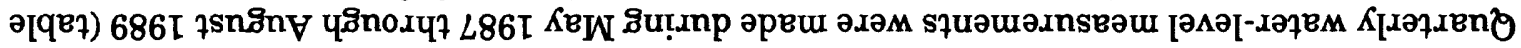

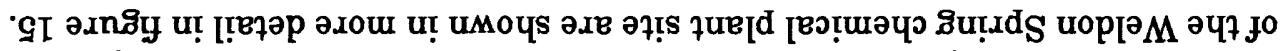

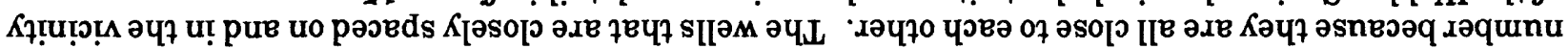

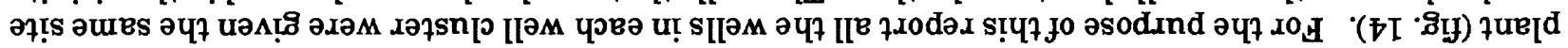




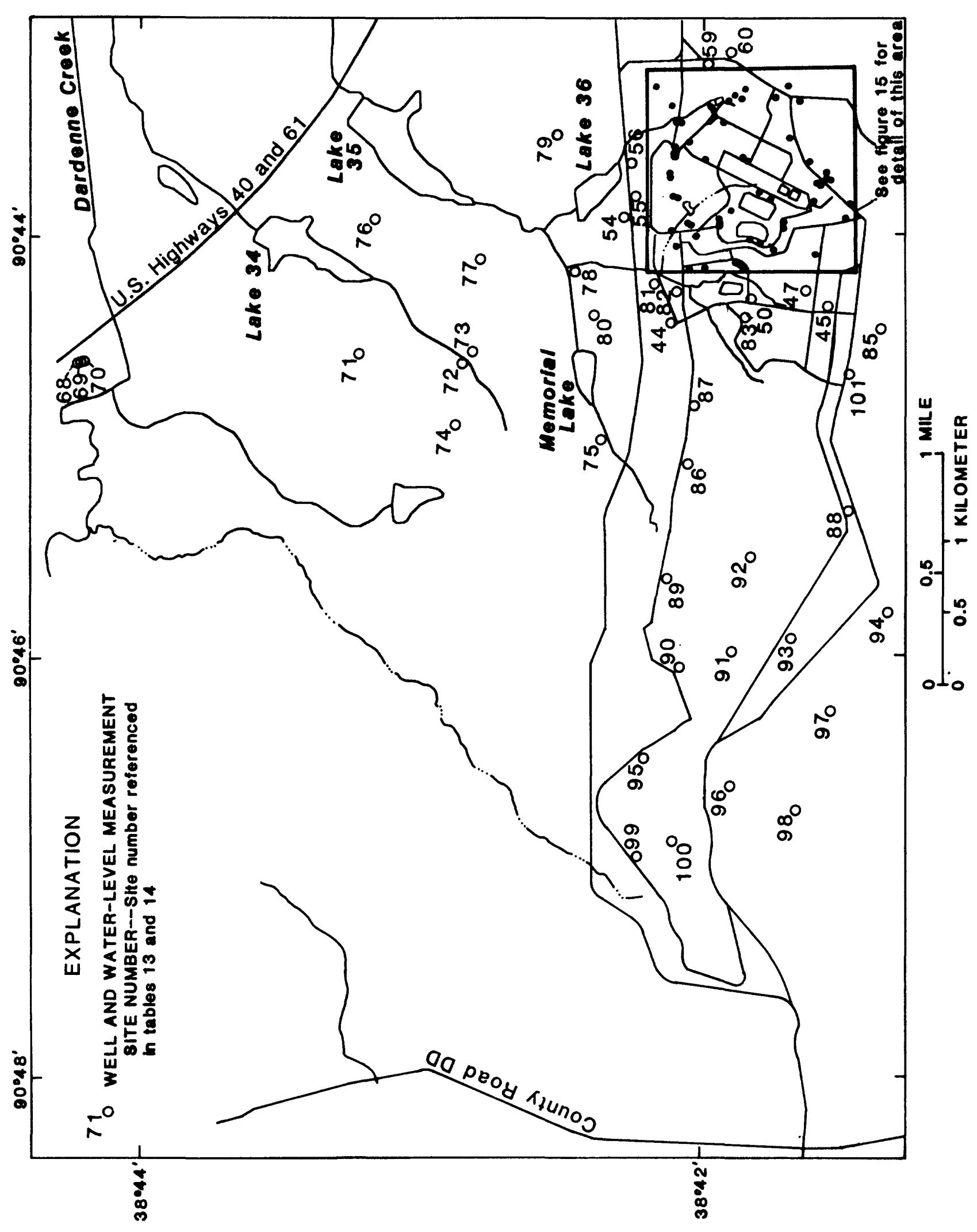

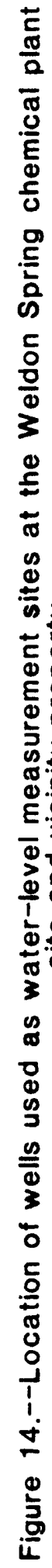


Kitedosd Kl!u!o!n pue el!s juejd jeo!meyo

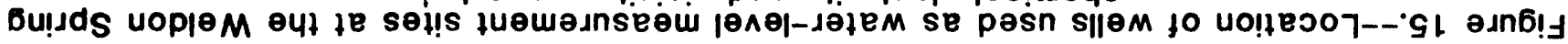

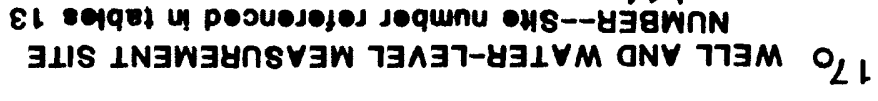

NOIL $\forall N \forall 7 d X \exists$
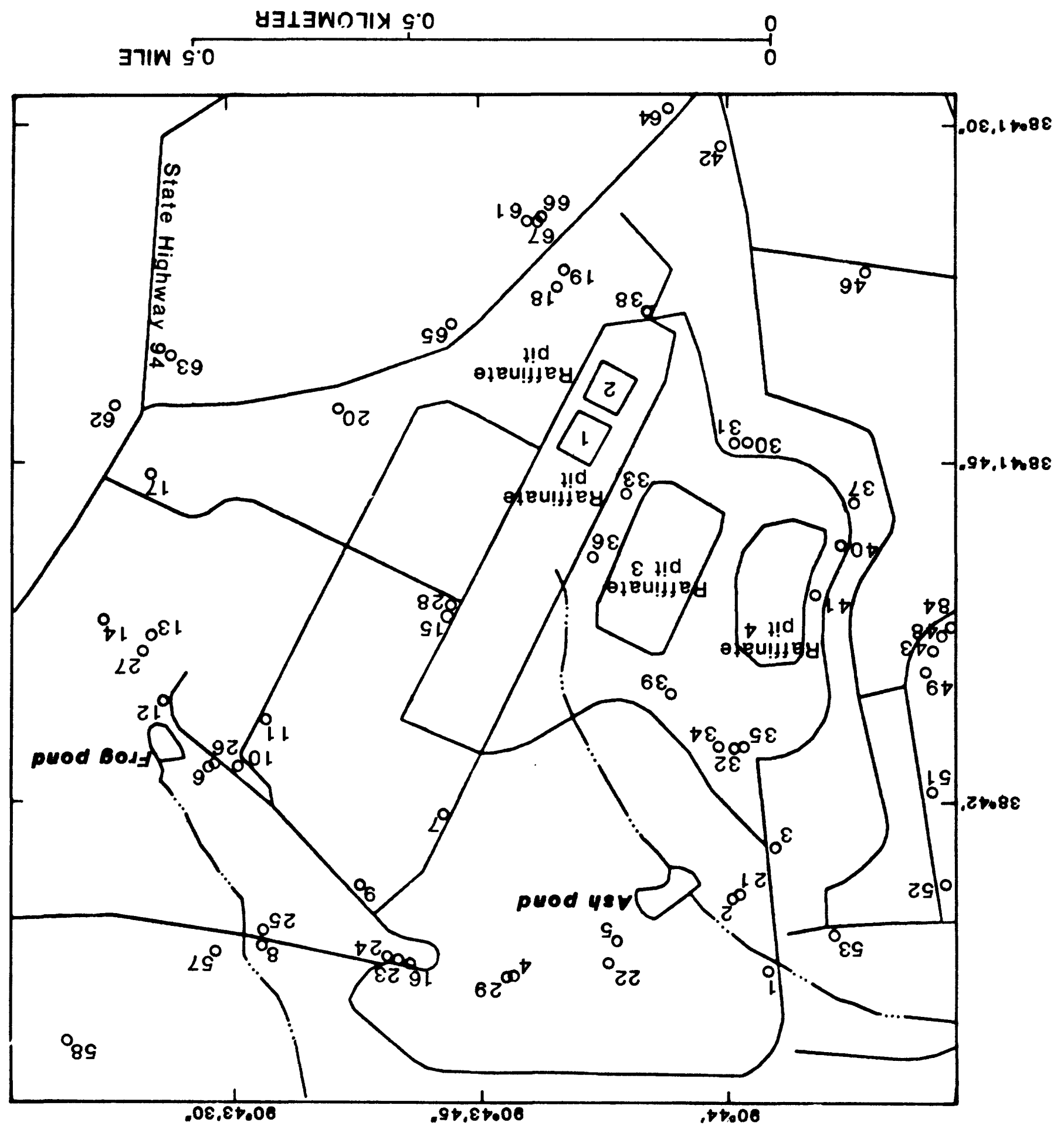


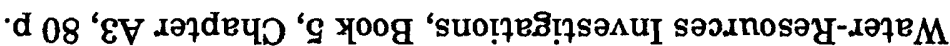

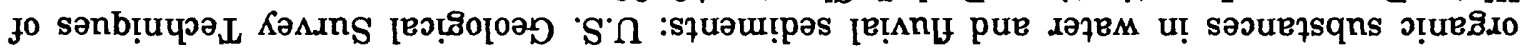

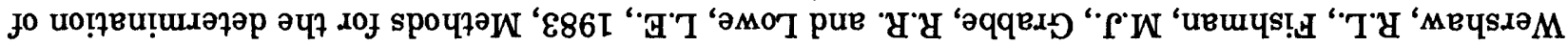

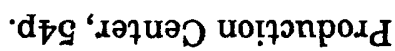

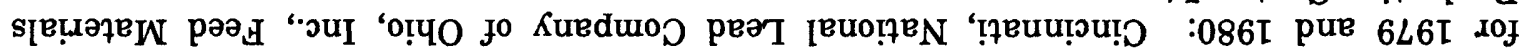

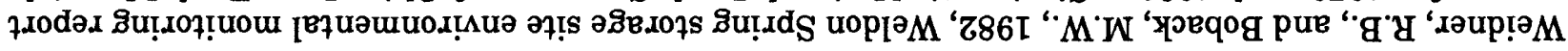

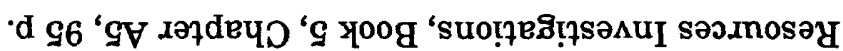

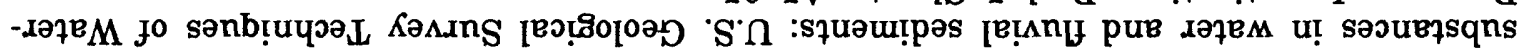

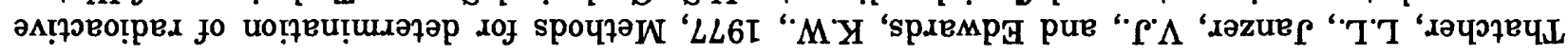

6-I 'ou 'E6 ^ $\wedge$ pue $؛ Z I-I \cdot$ ou

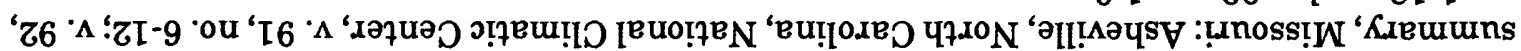

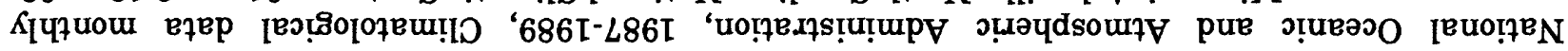

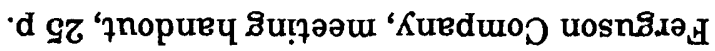

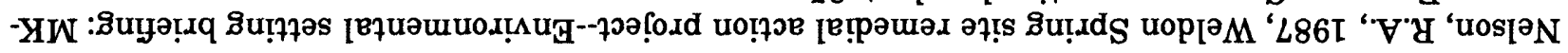
'x!puədde чұṭ "

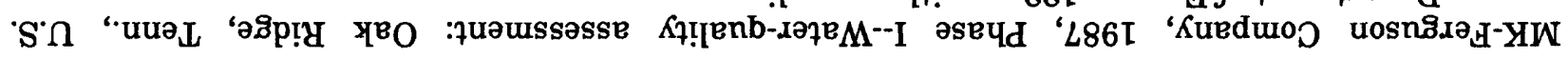

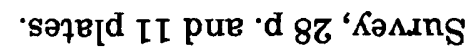

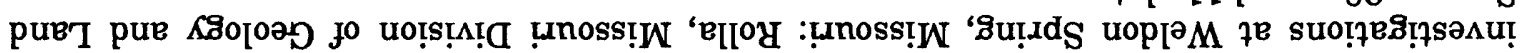

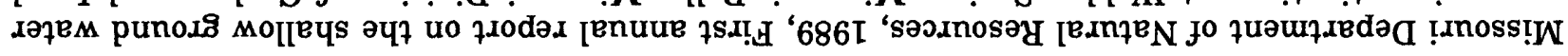

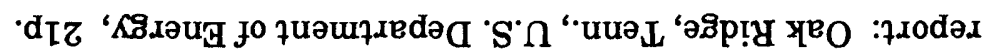

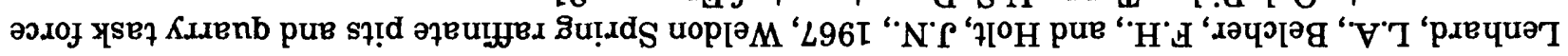

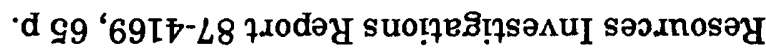

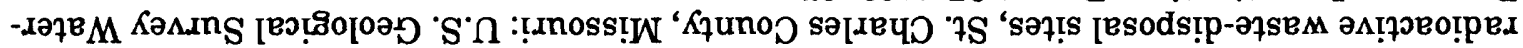

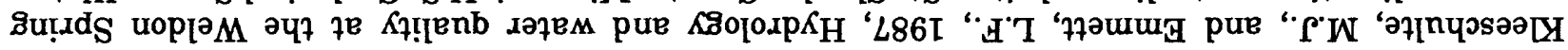

- $\alpha$ xtpuədde 'II ${ }^{\Lambda}$

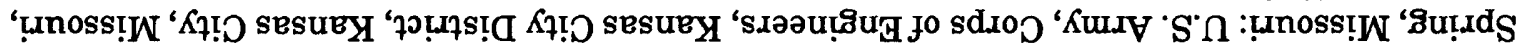

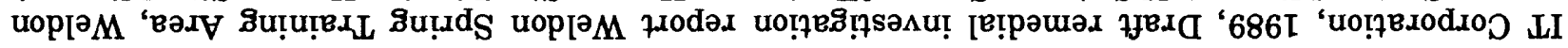

-d 979 'IF

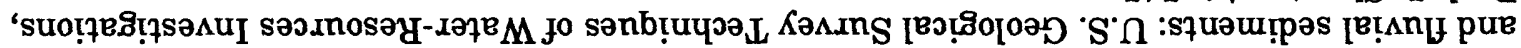

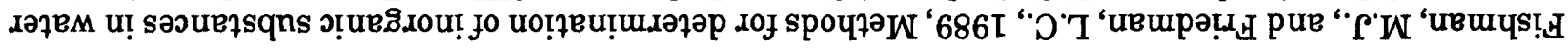

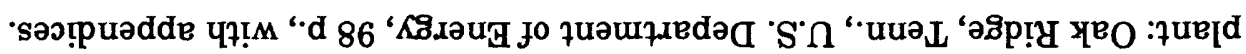

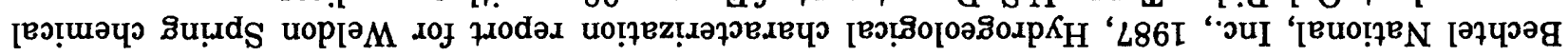

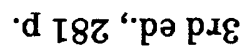

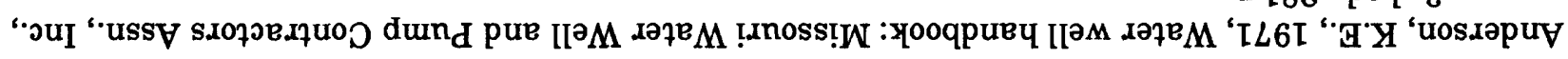




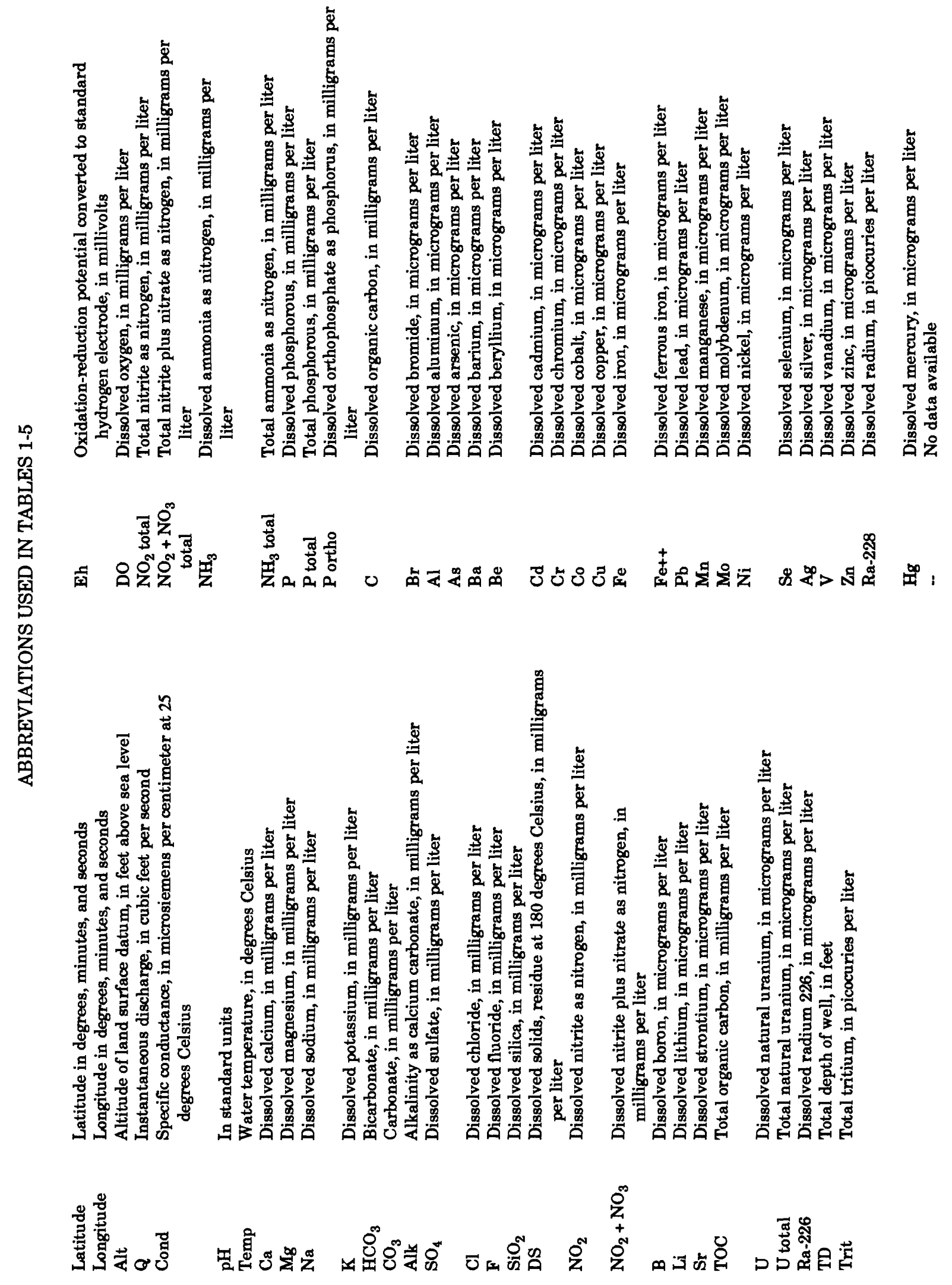




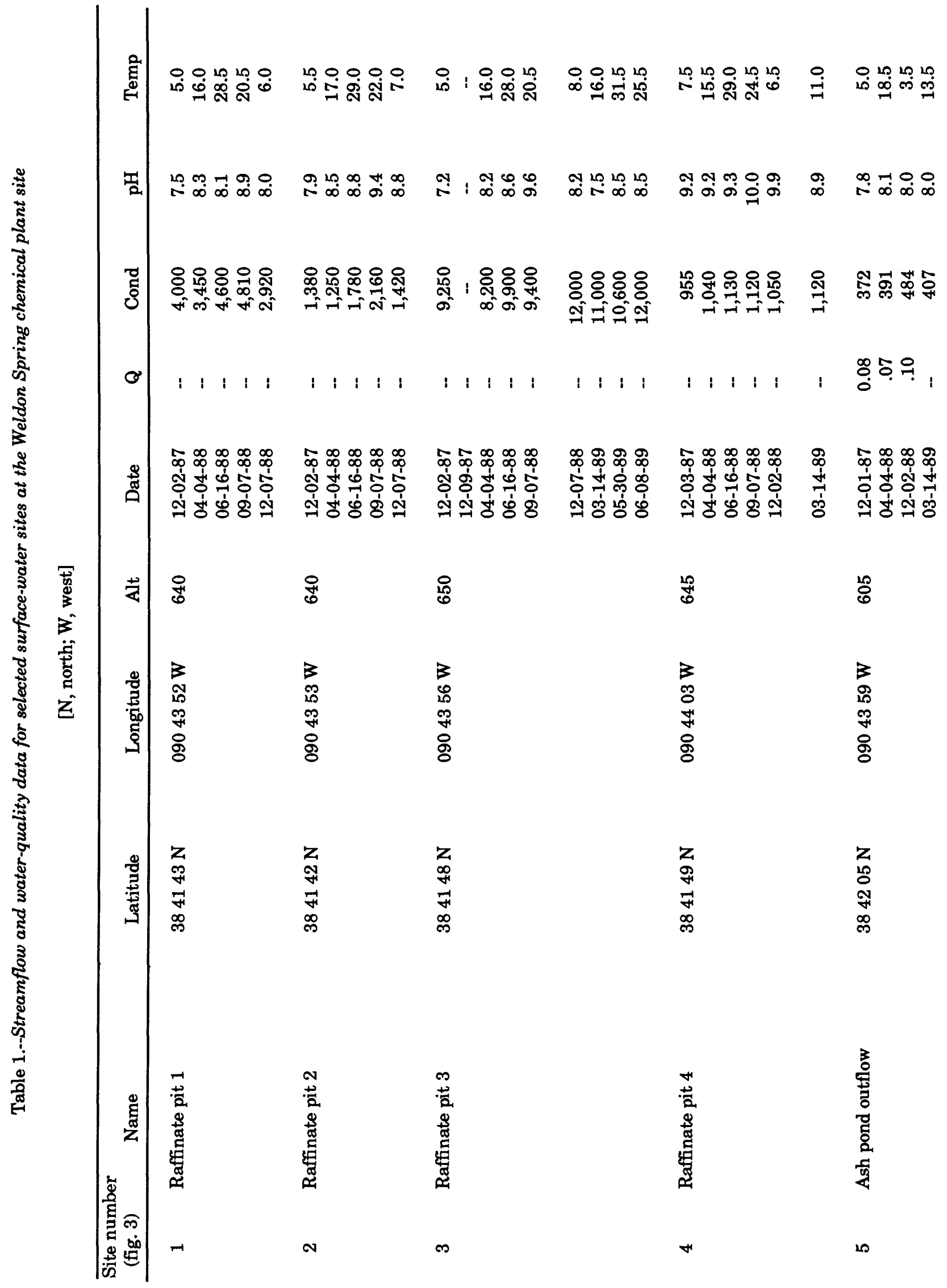




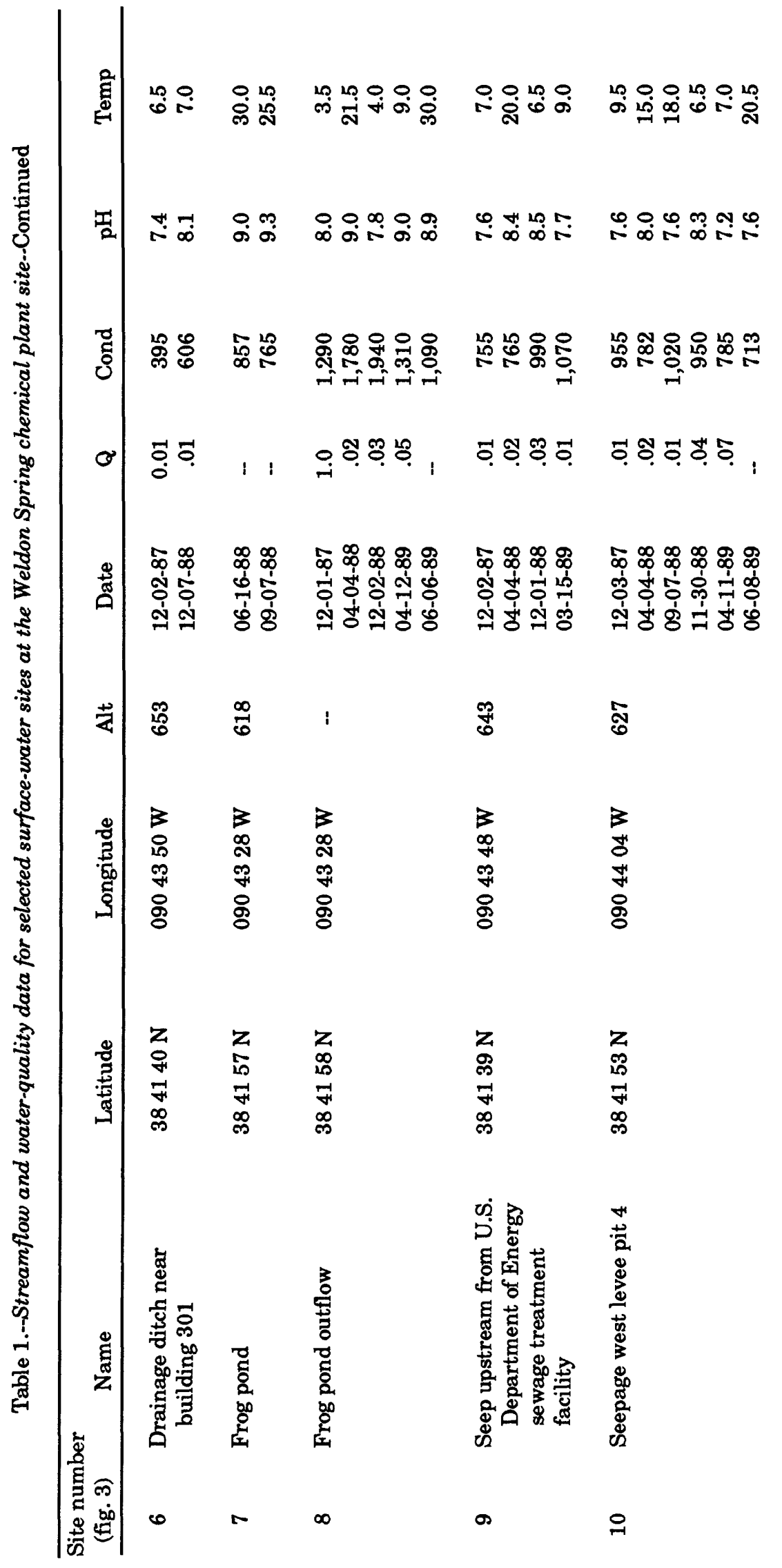




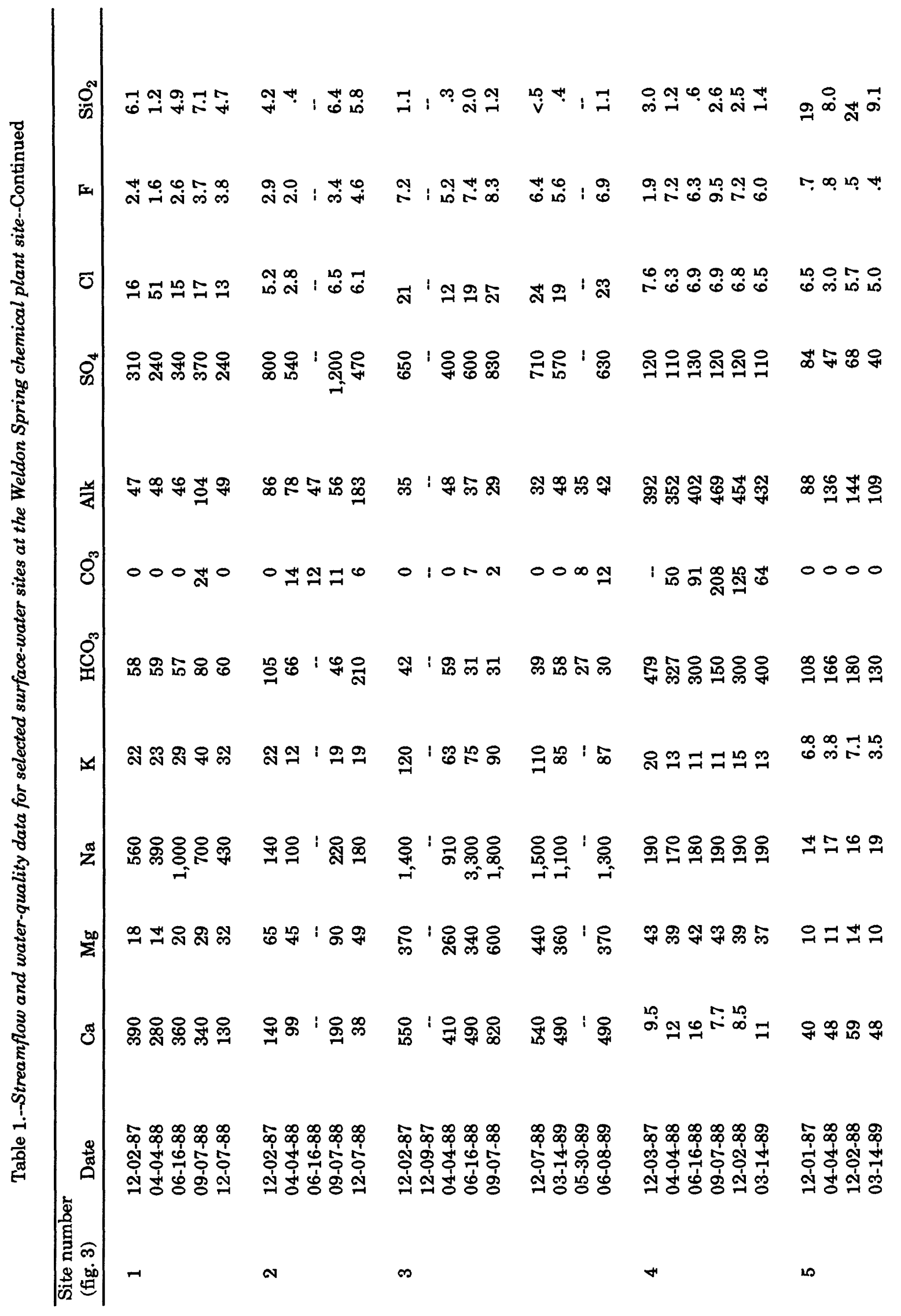




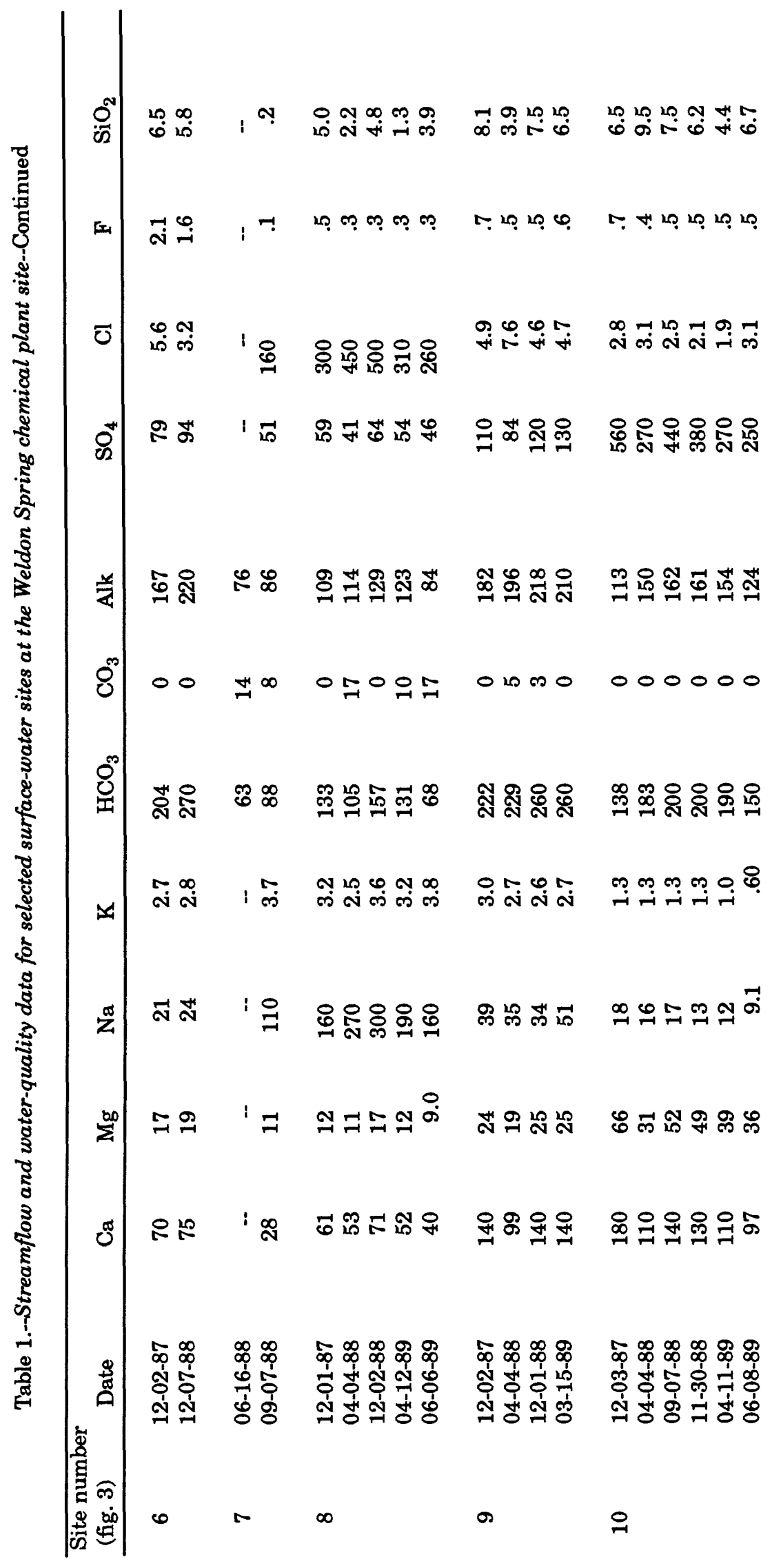




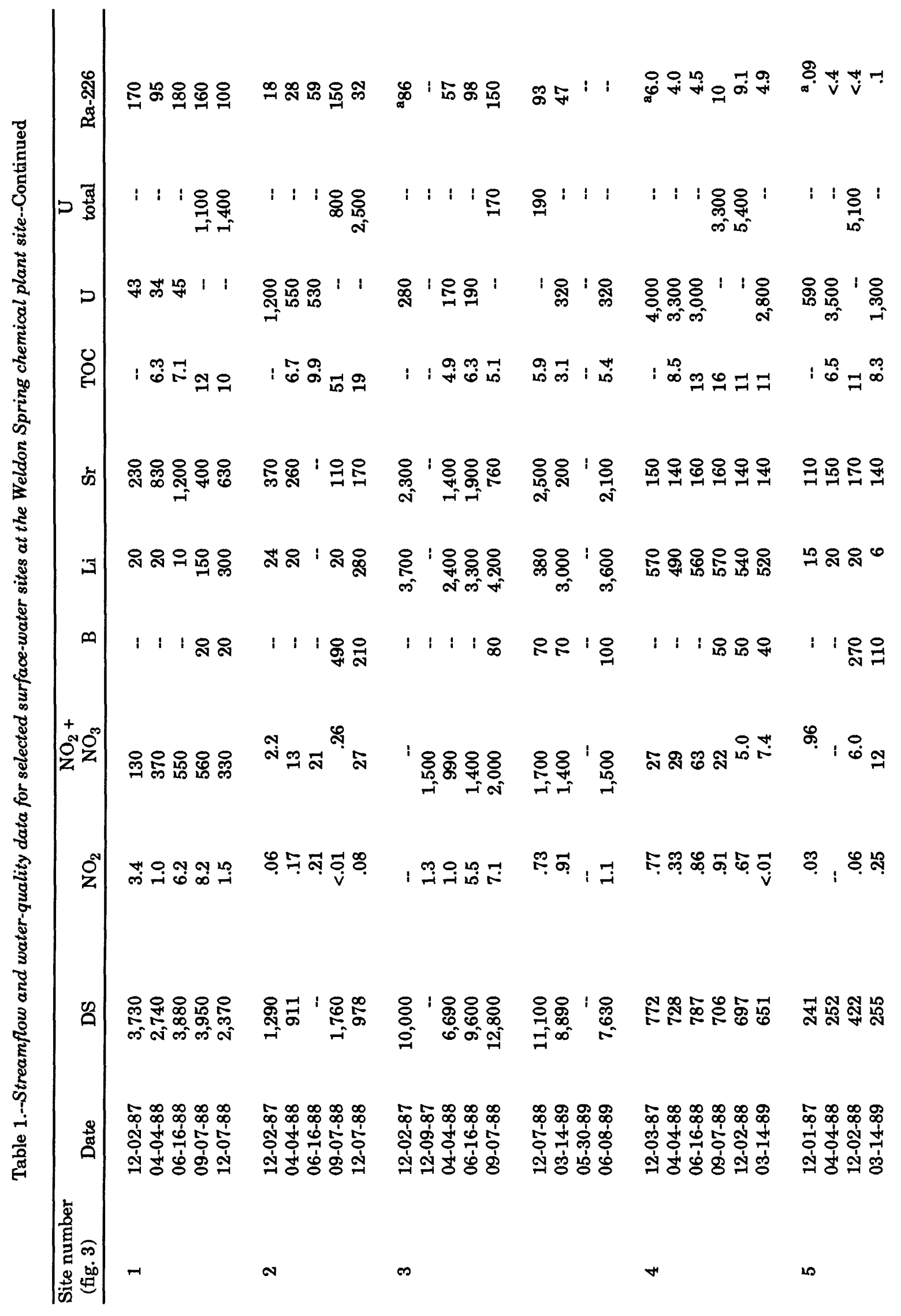




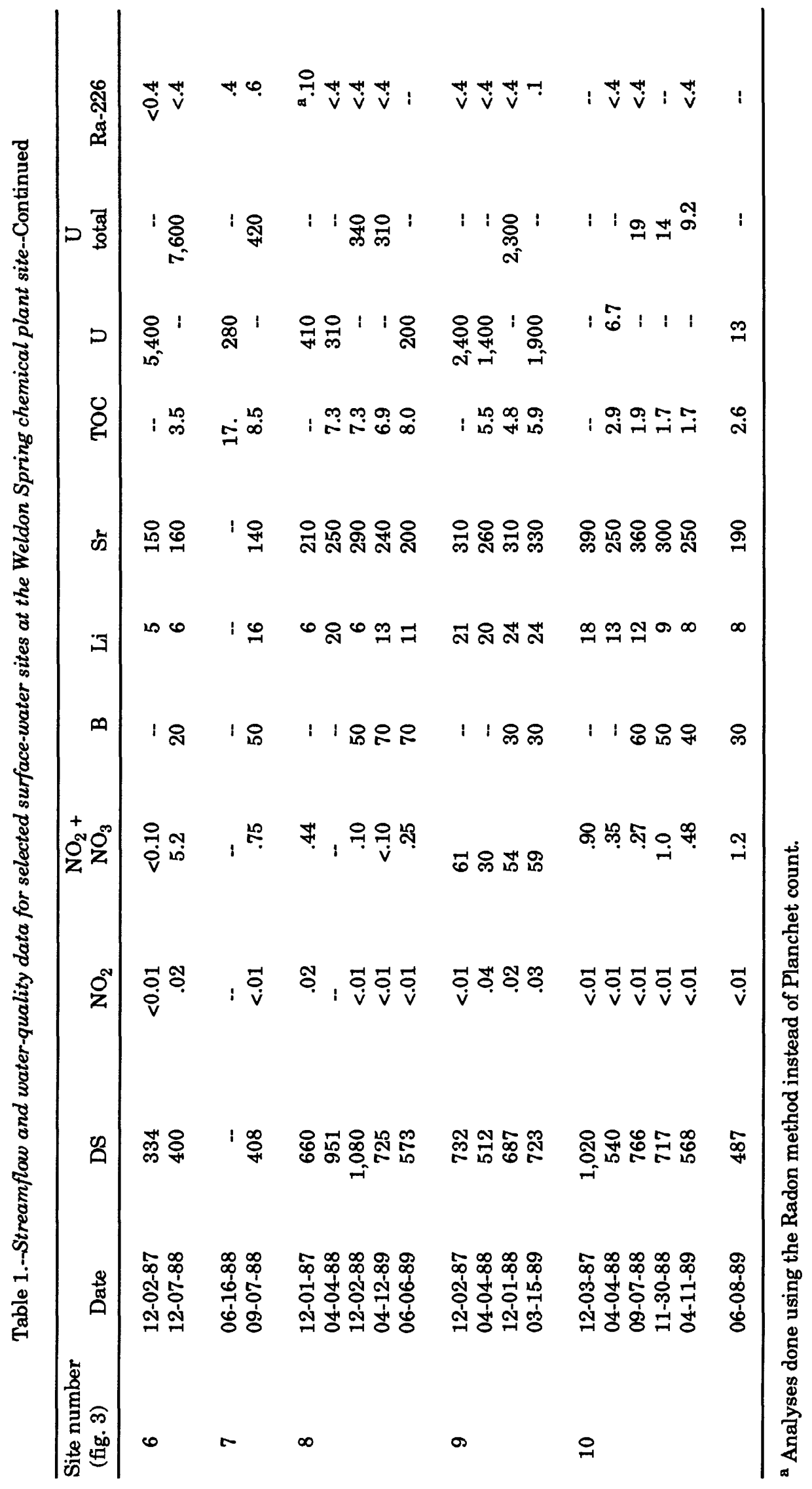




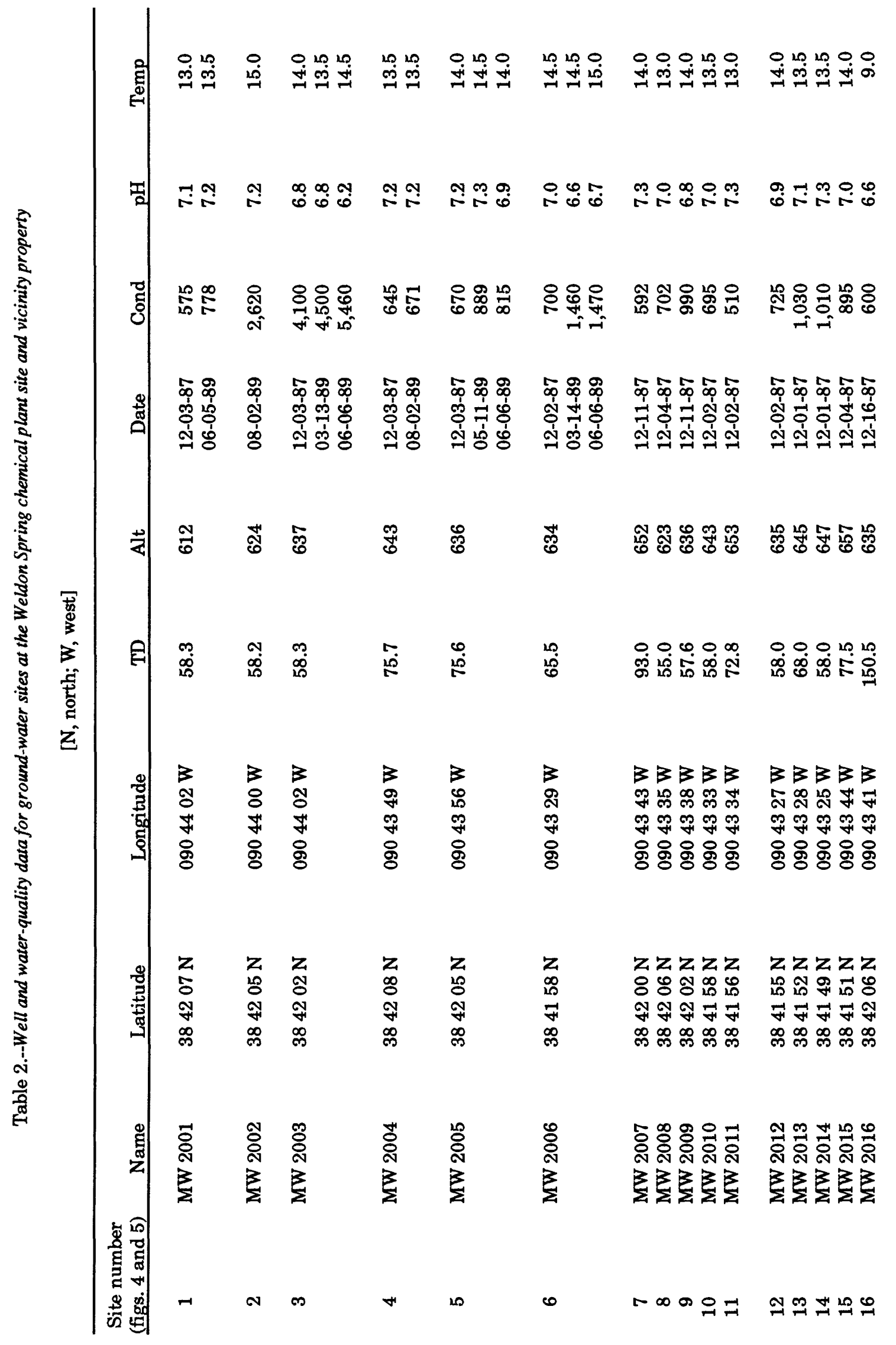




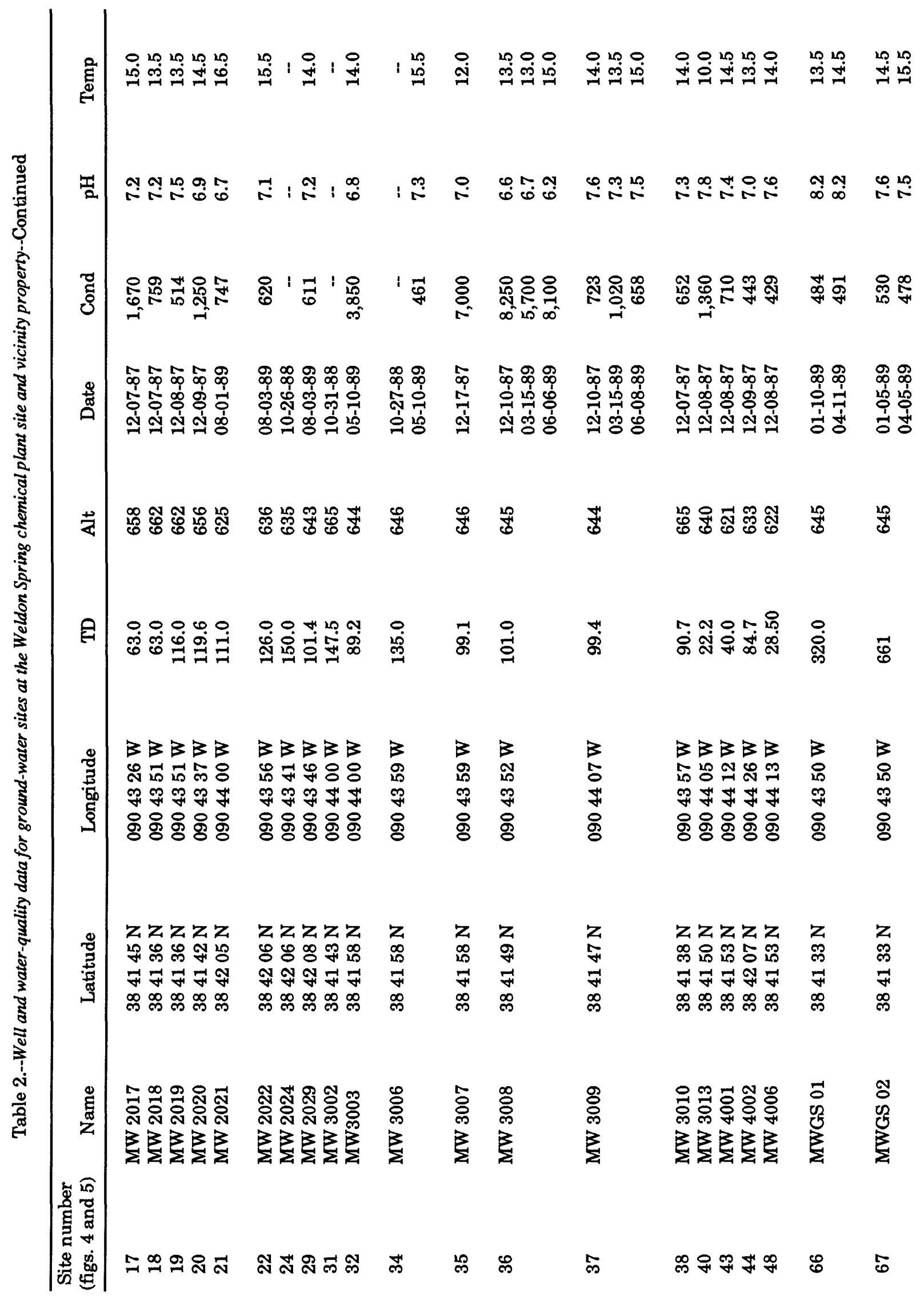




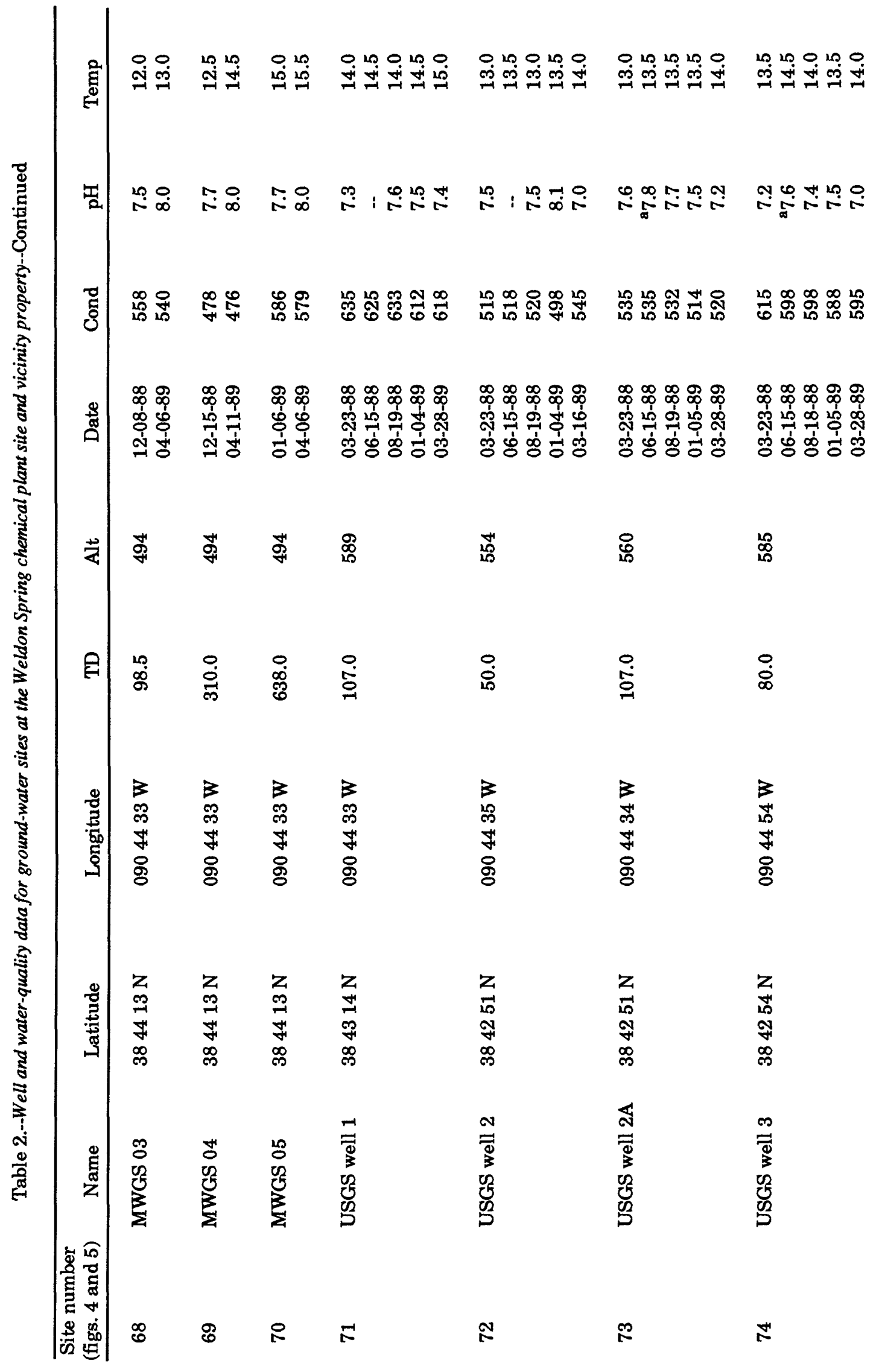




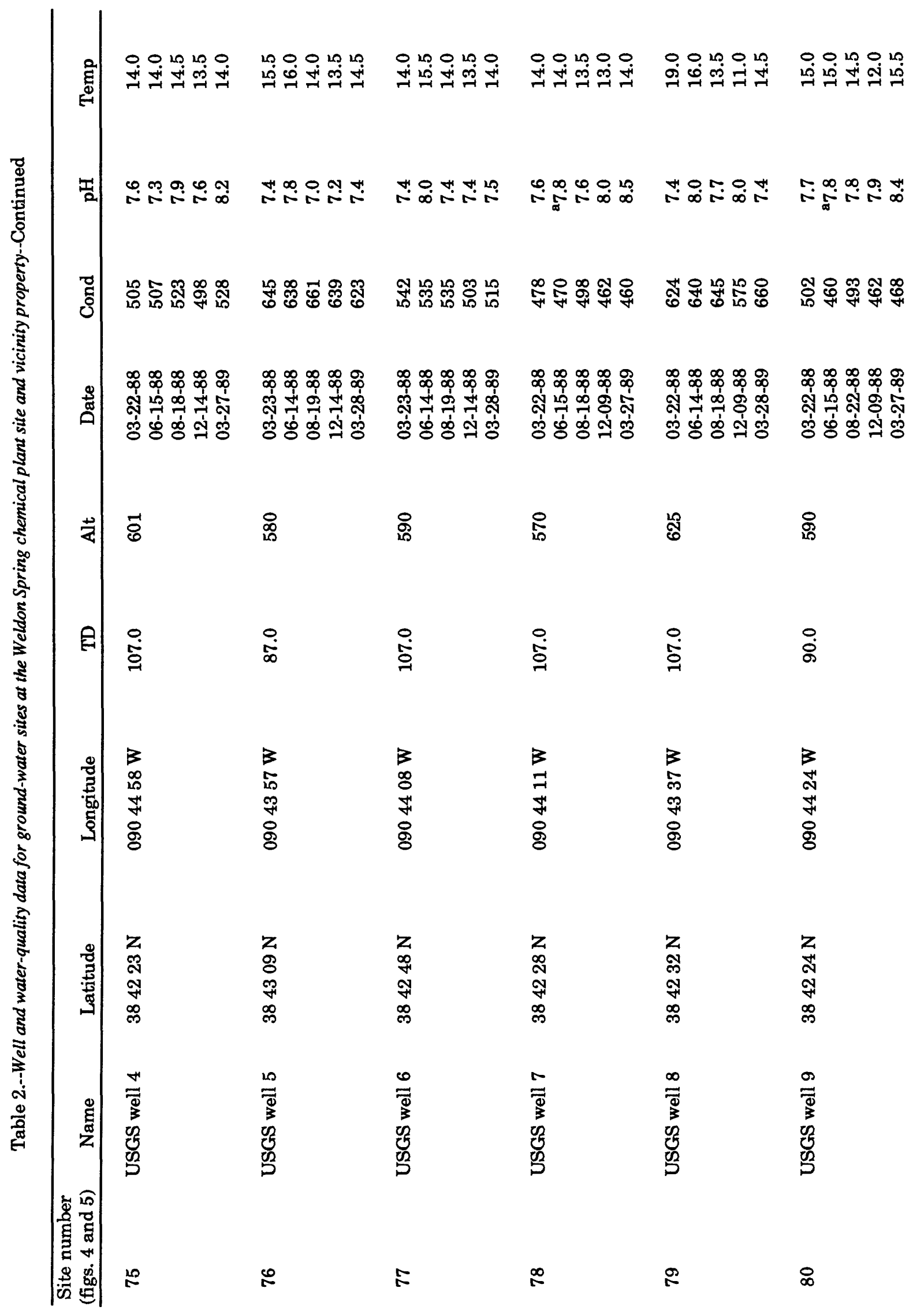




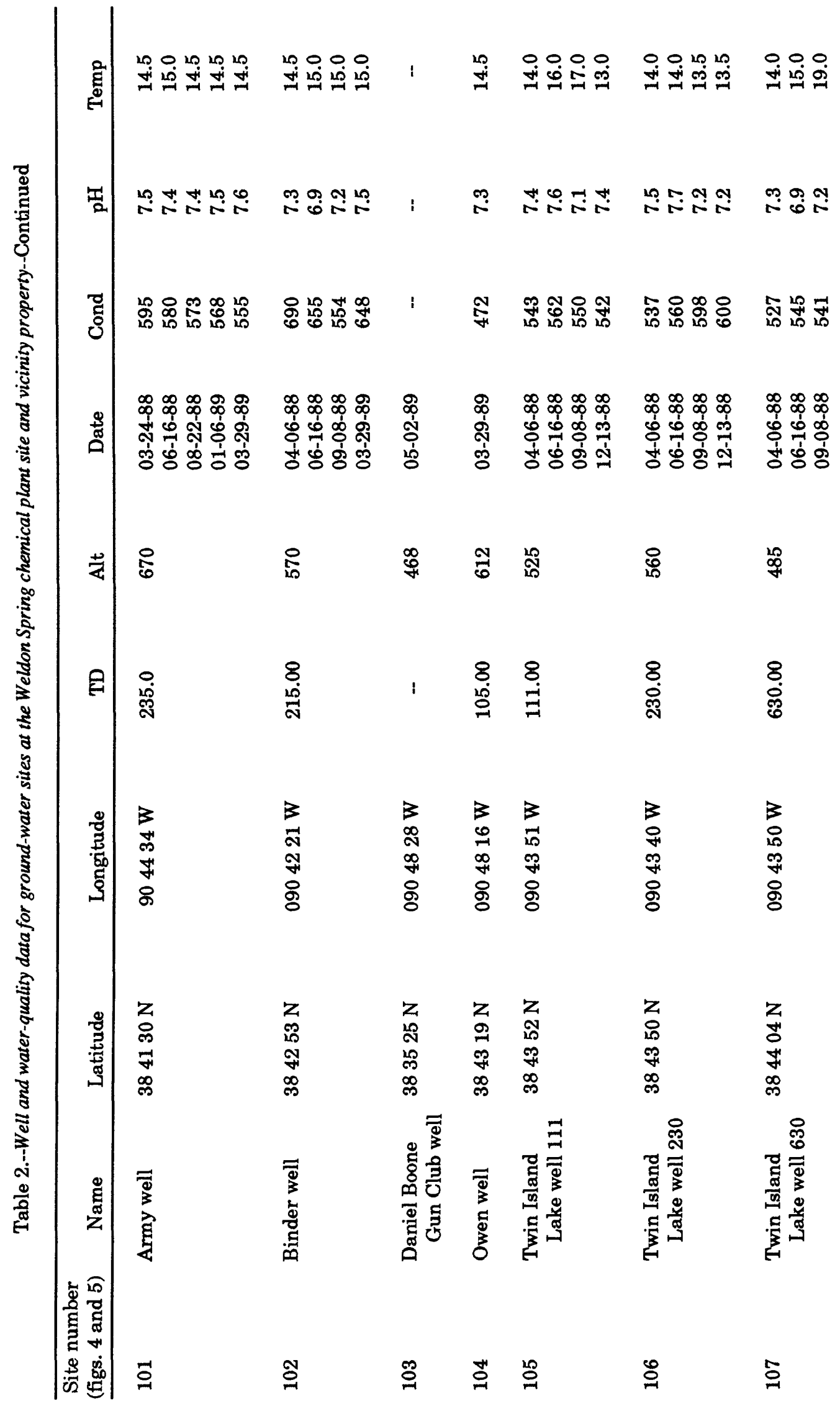




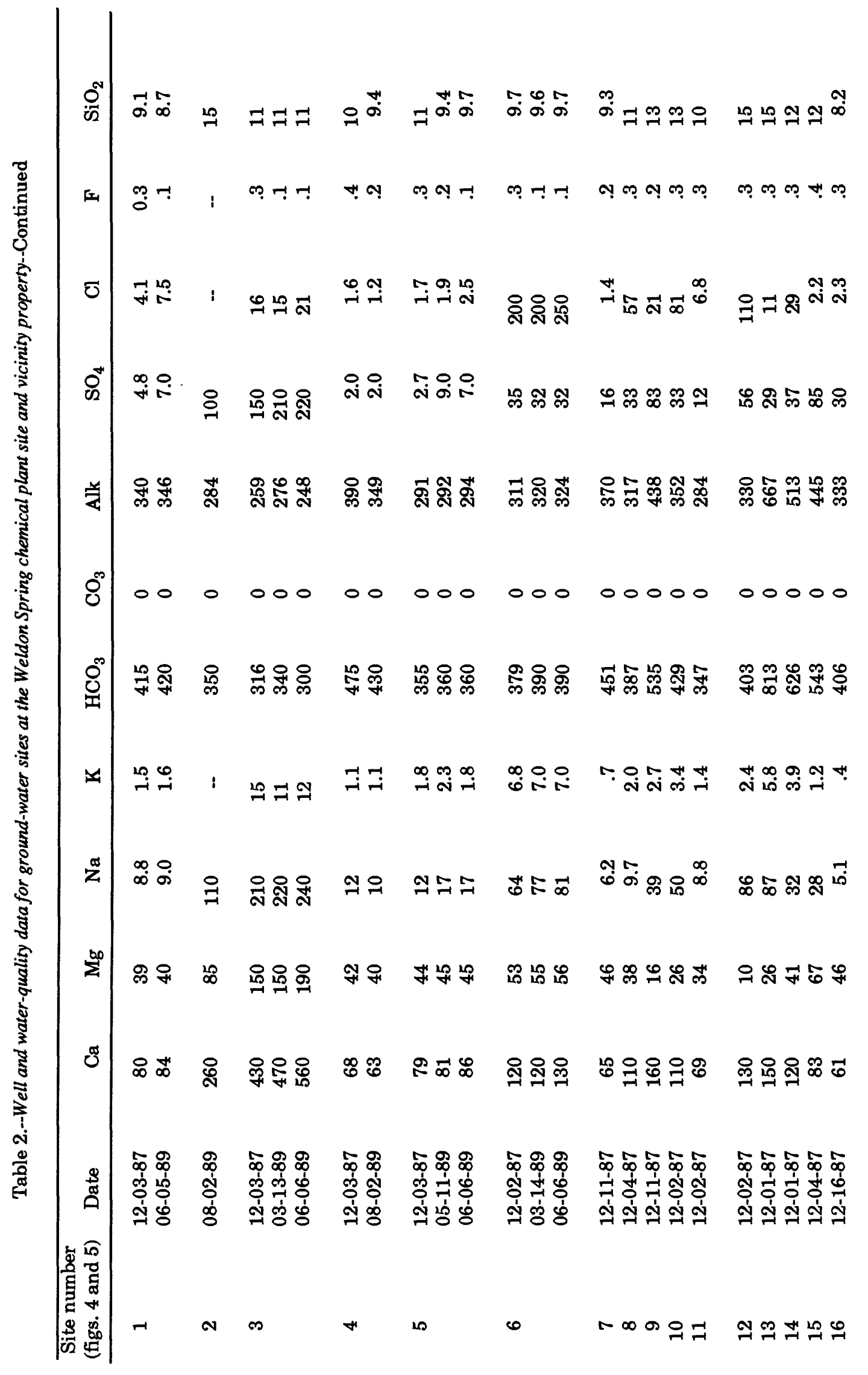




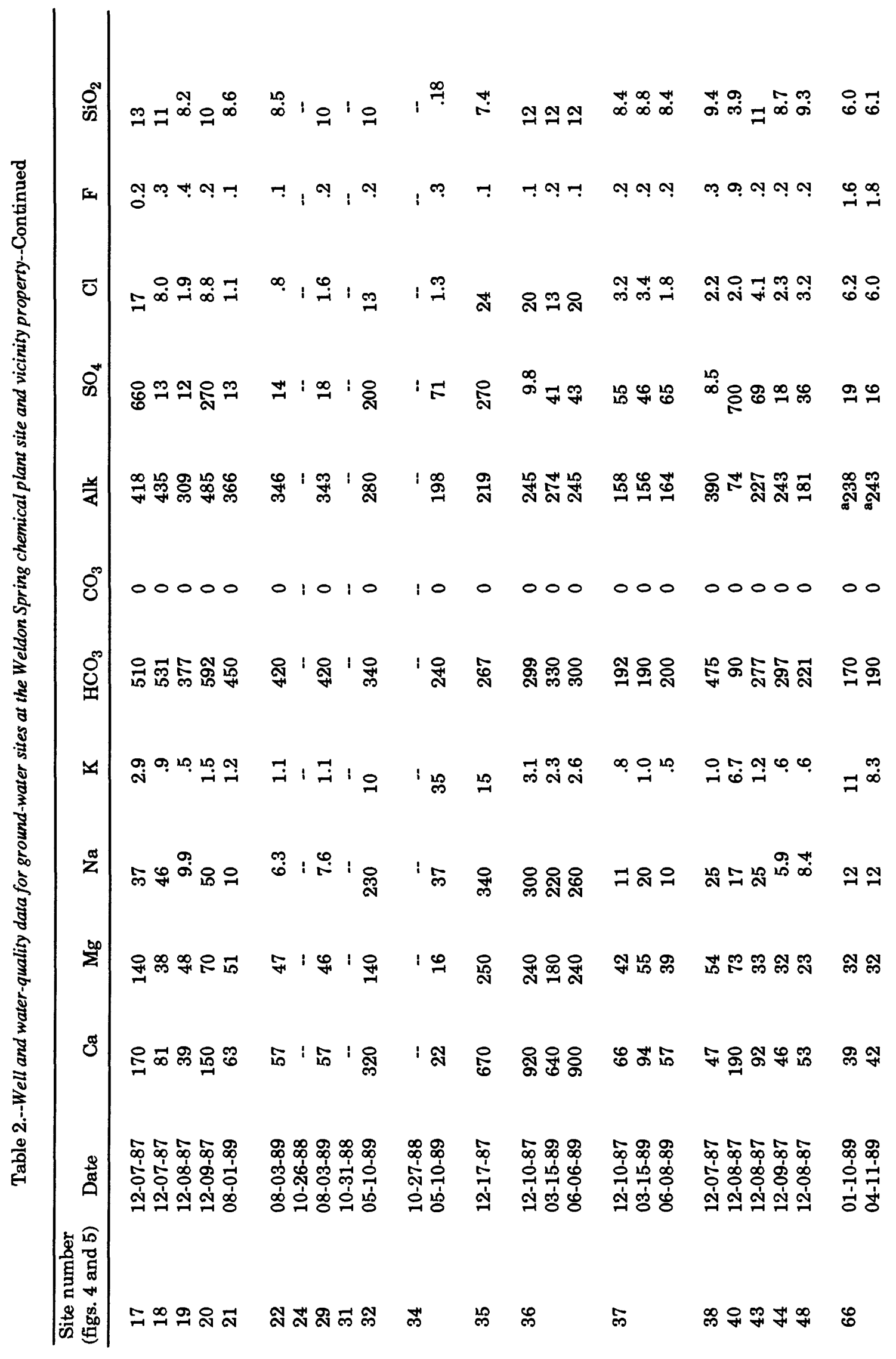




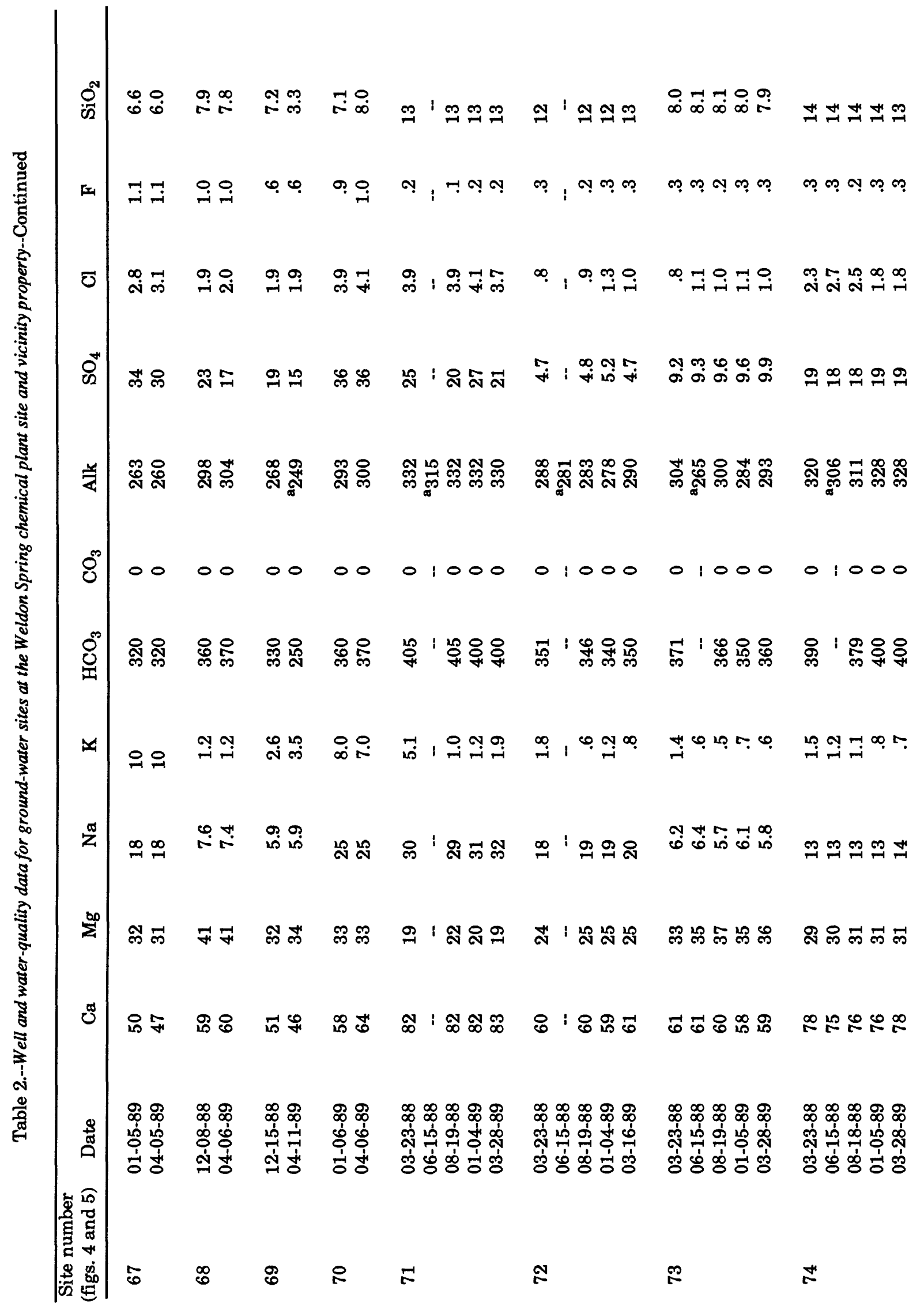




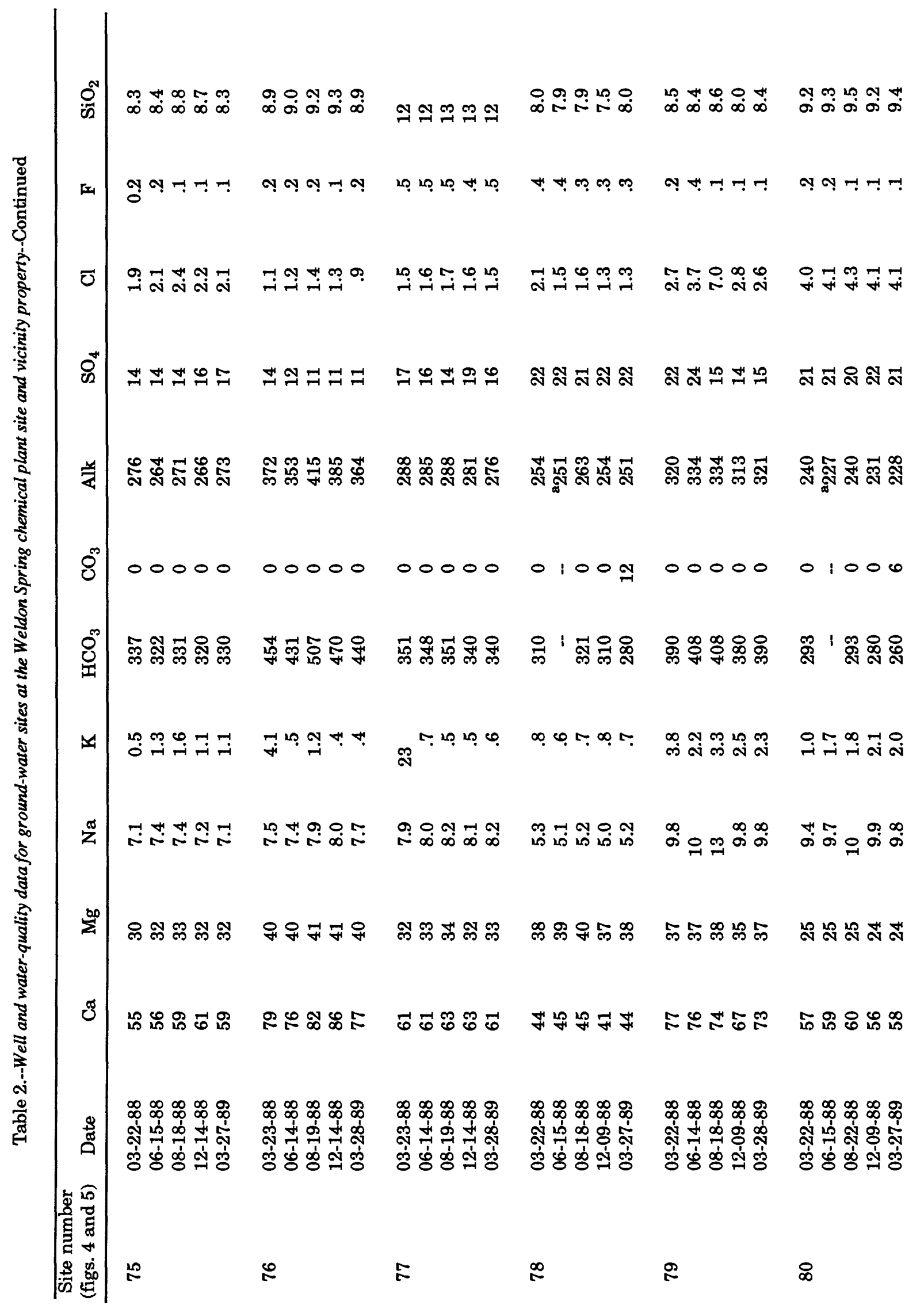




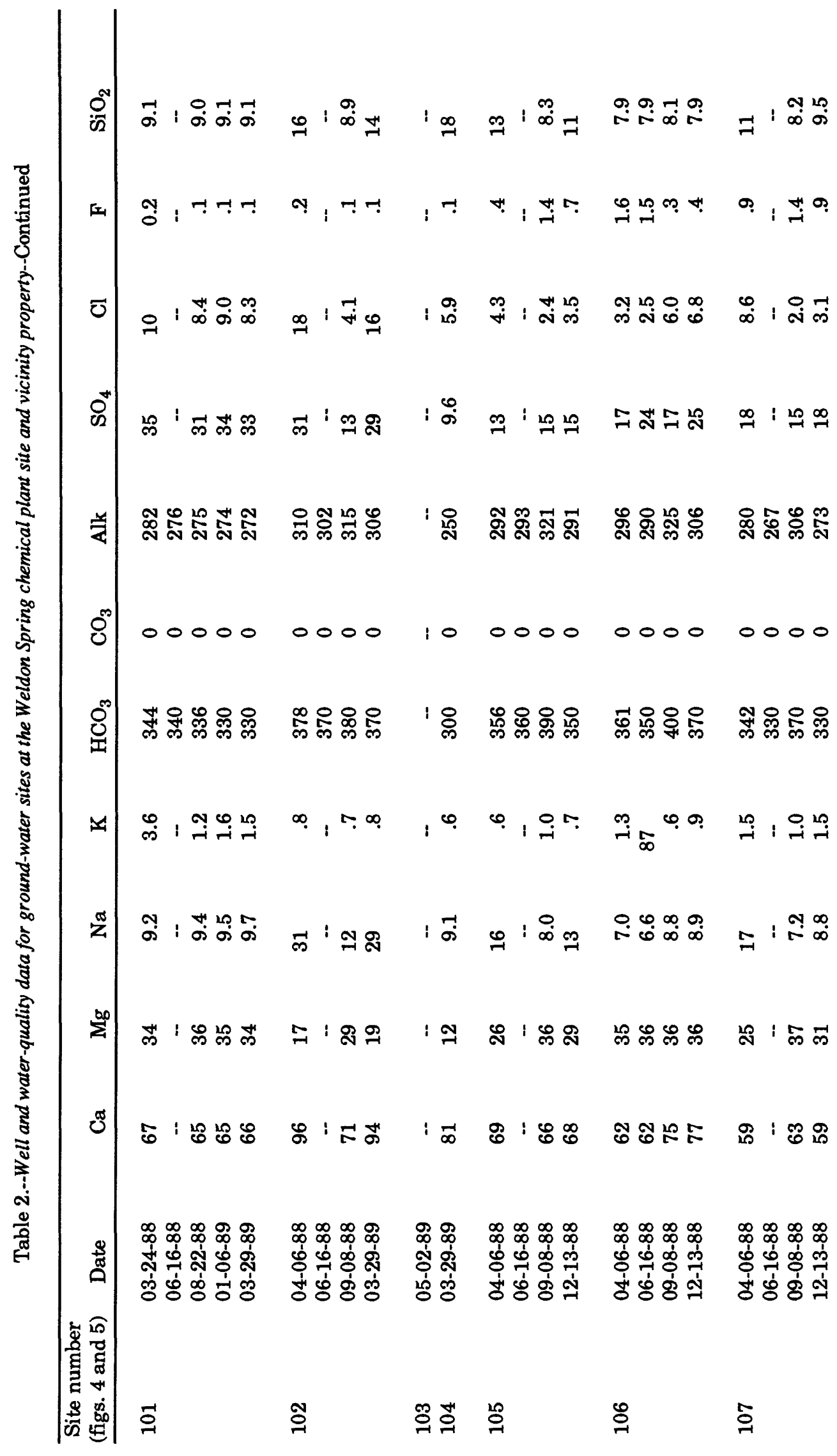




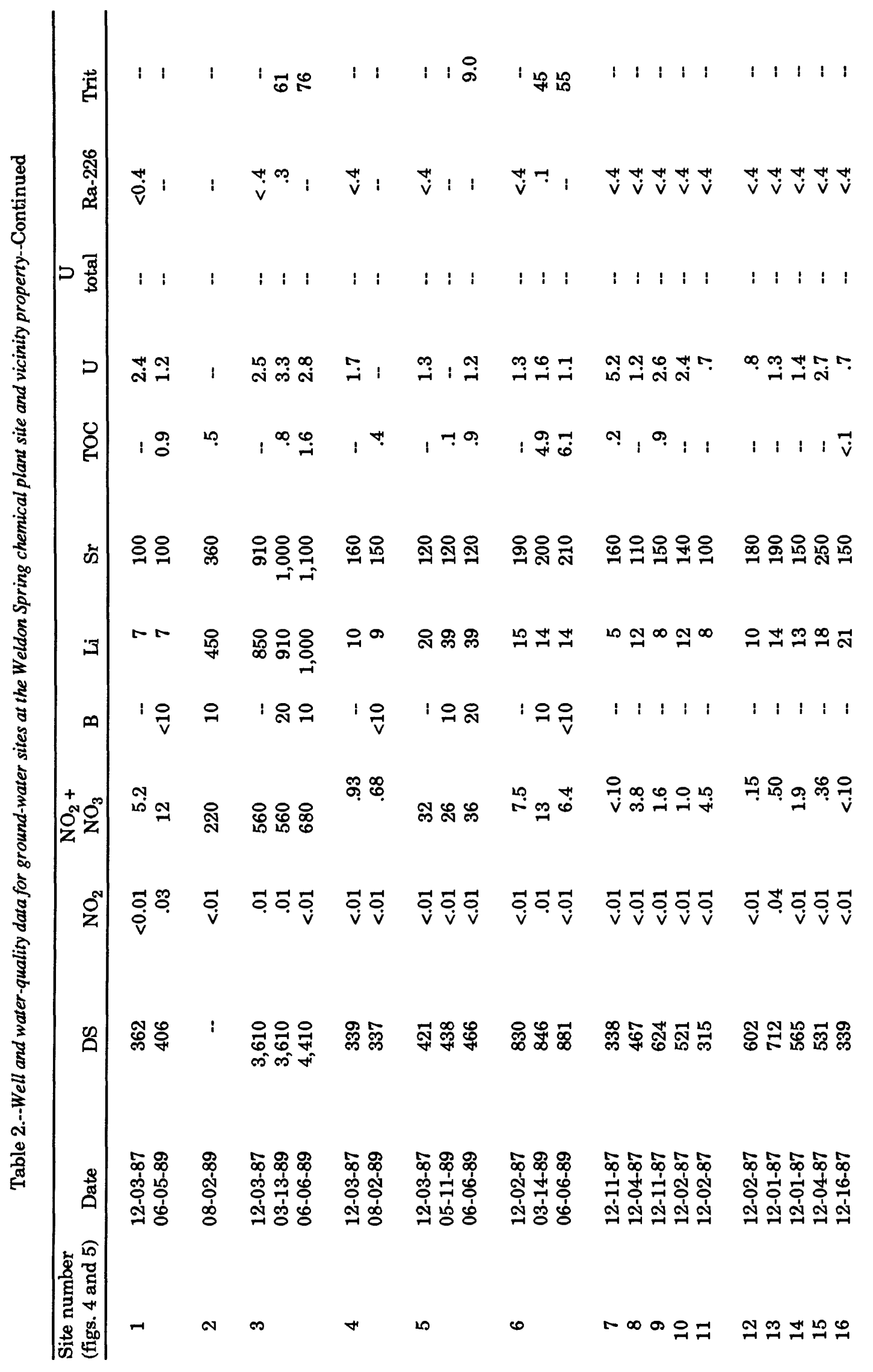




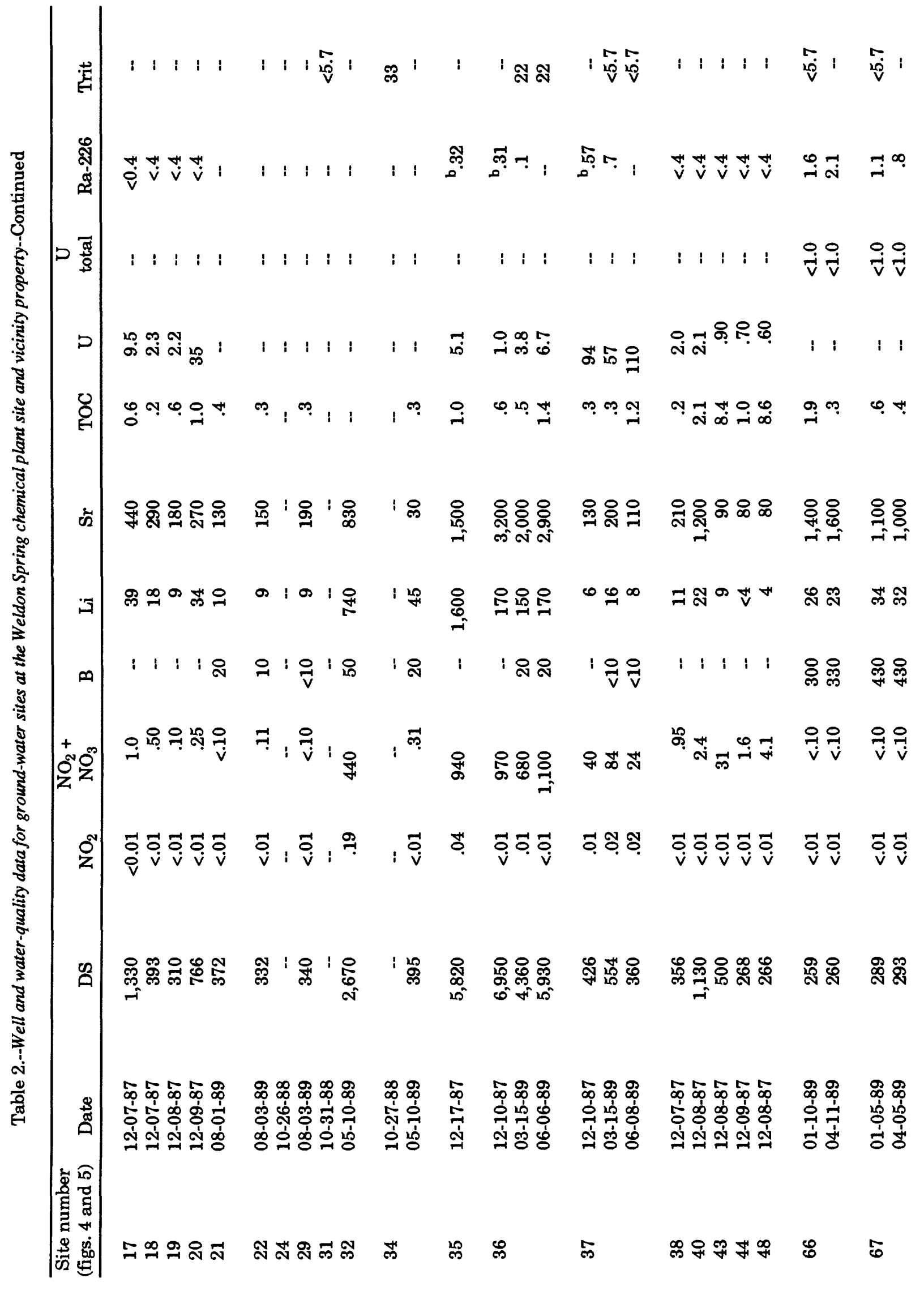




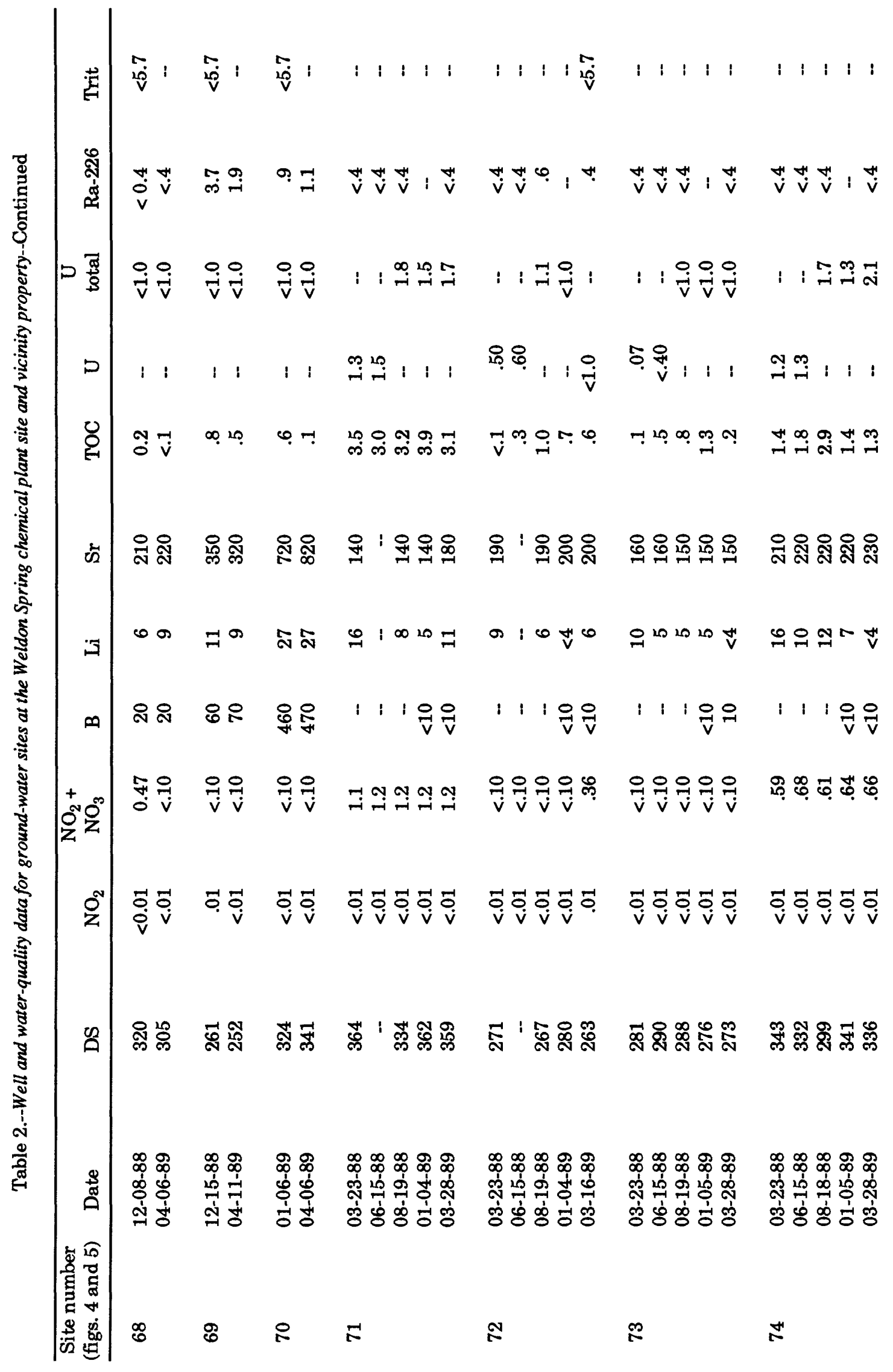




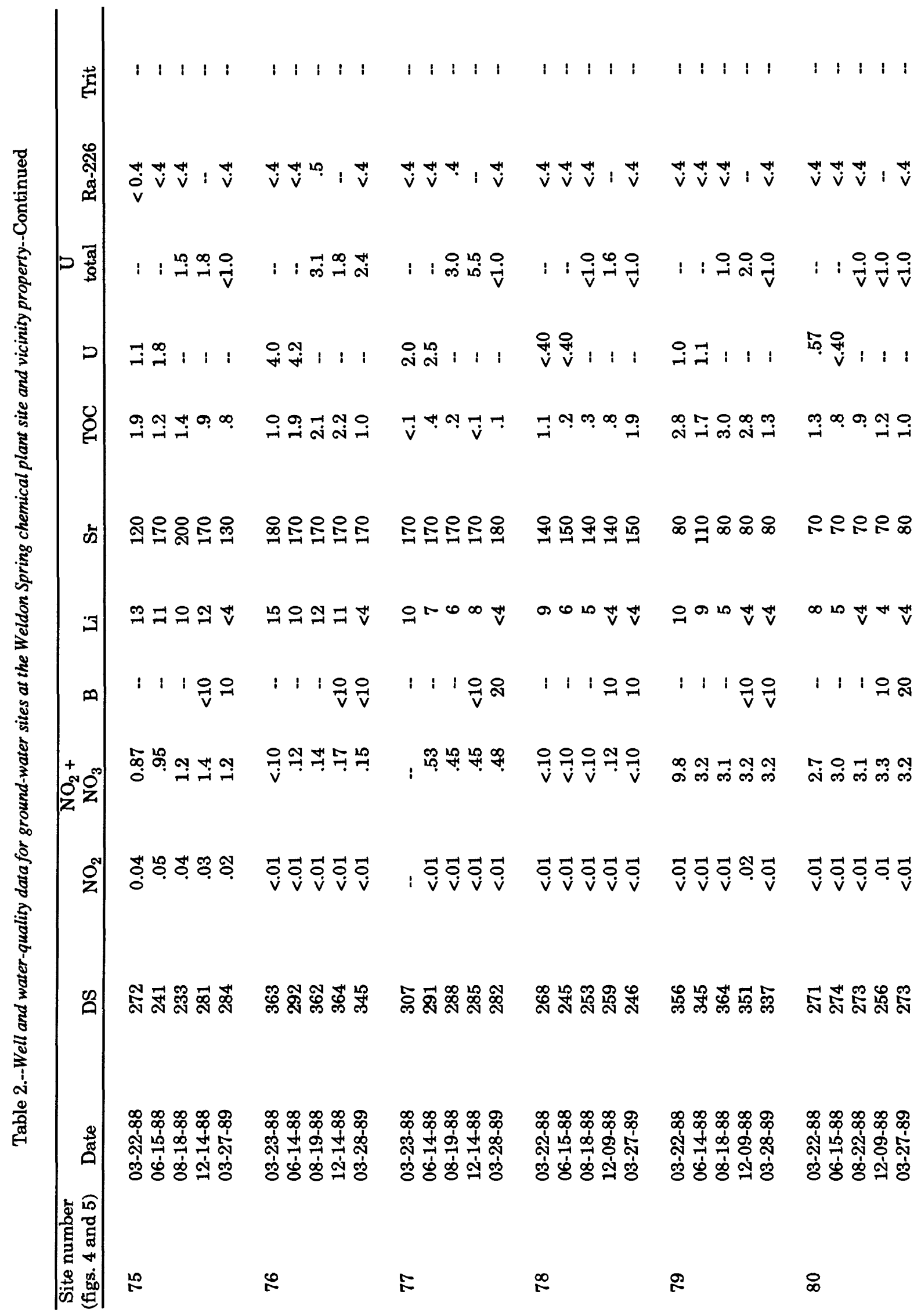




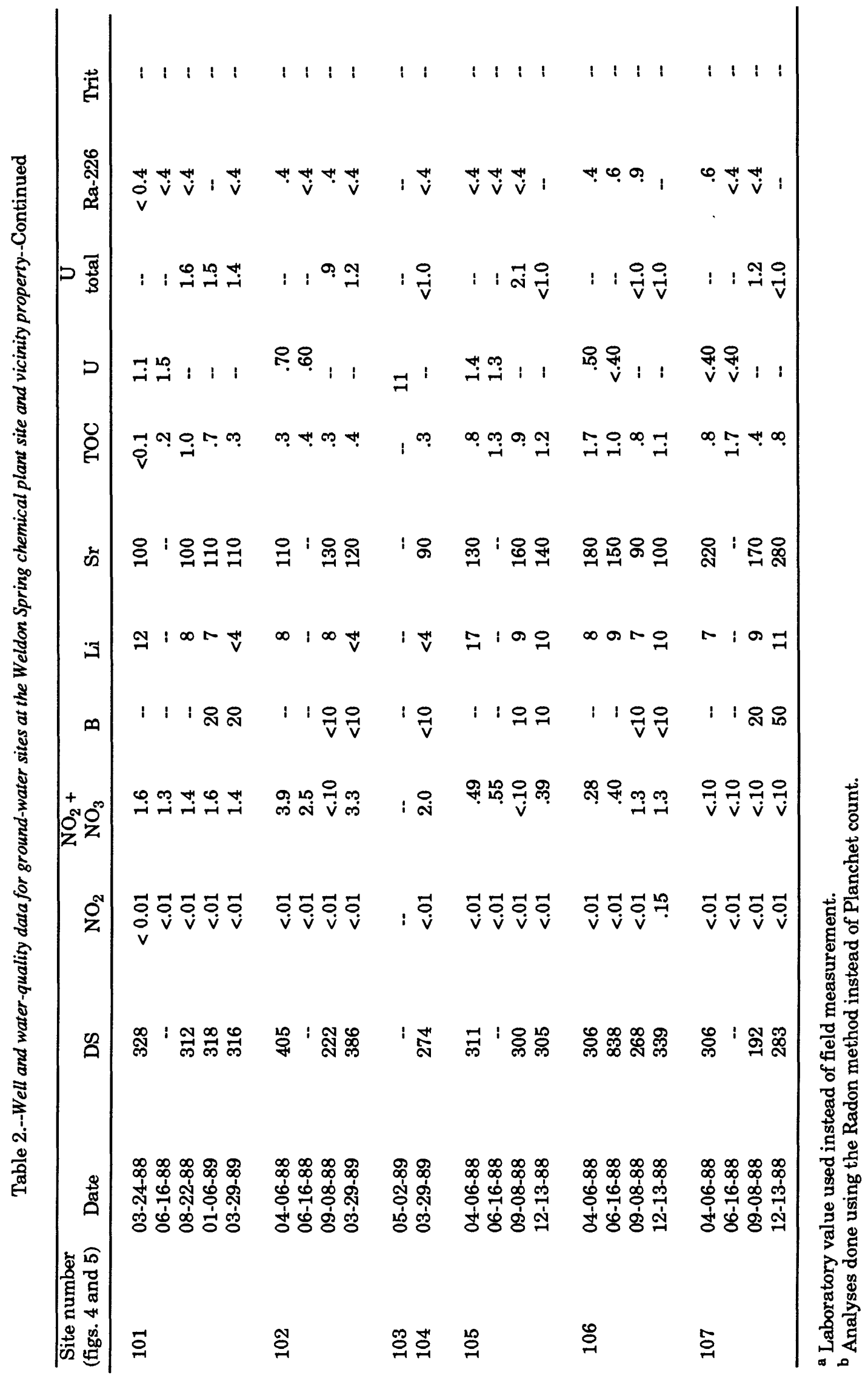




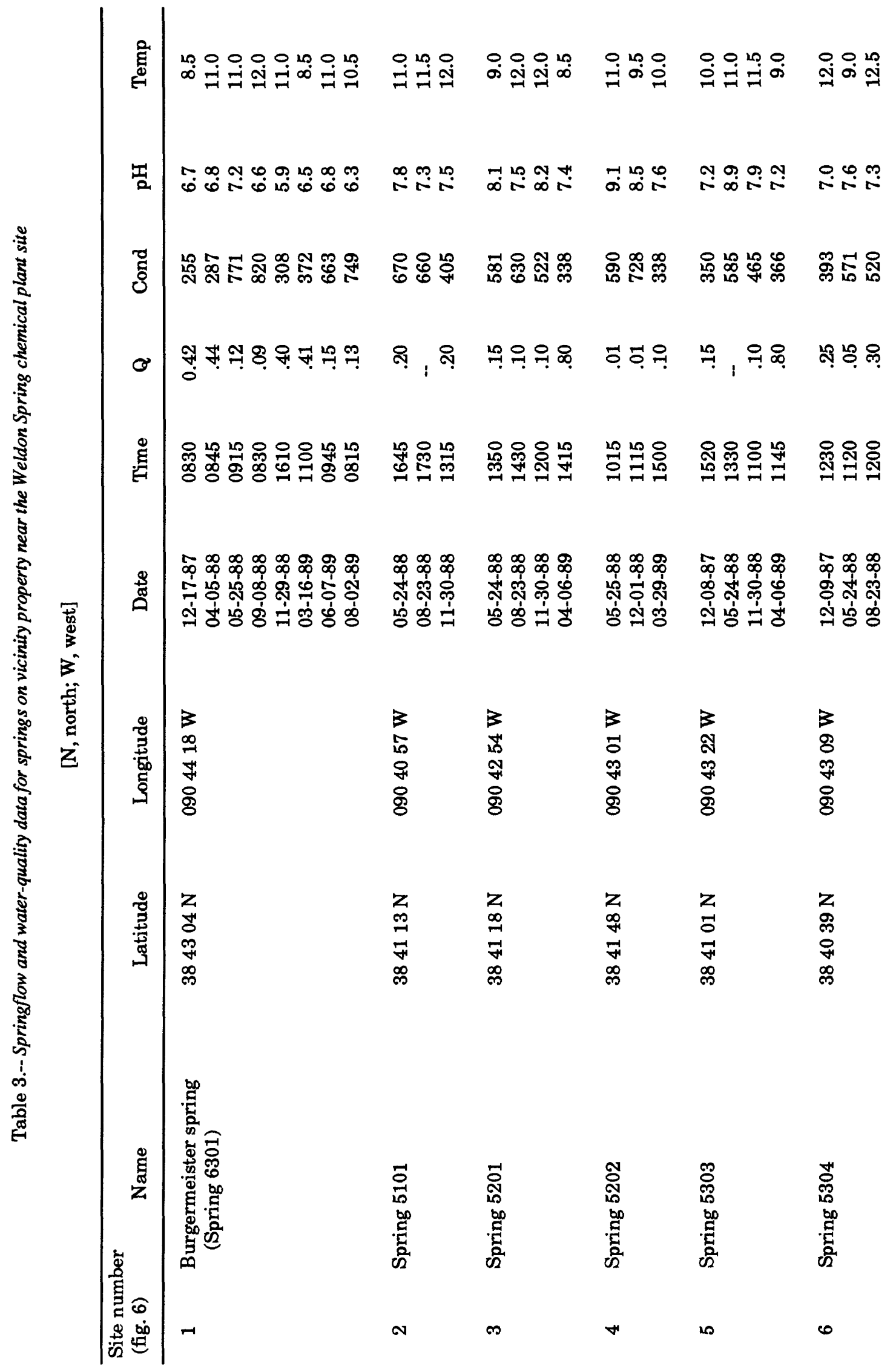




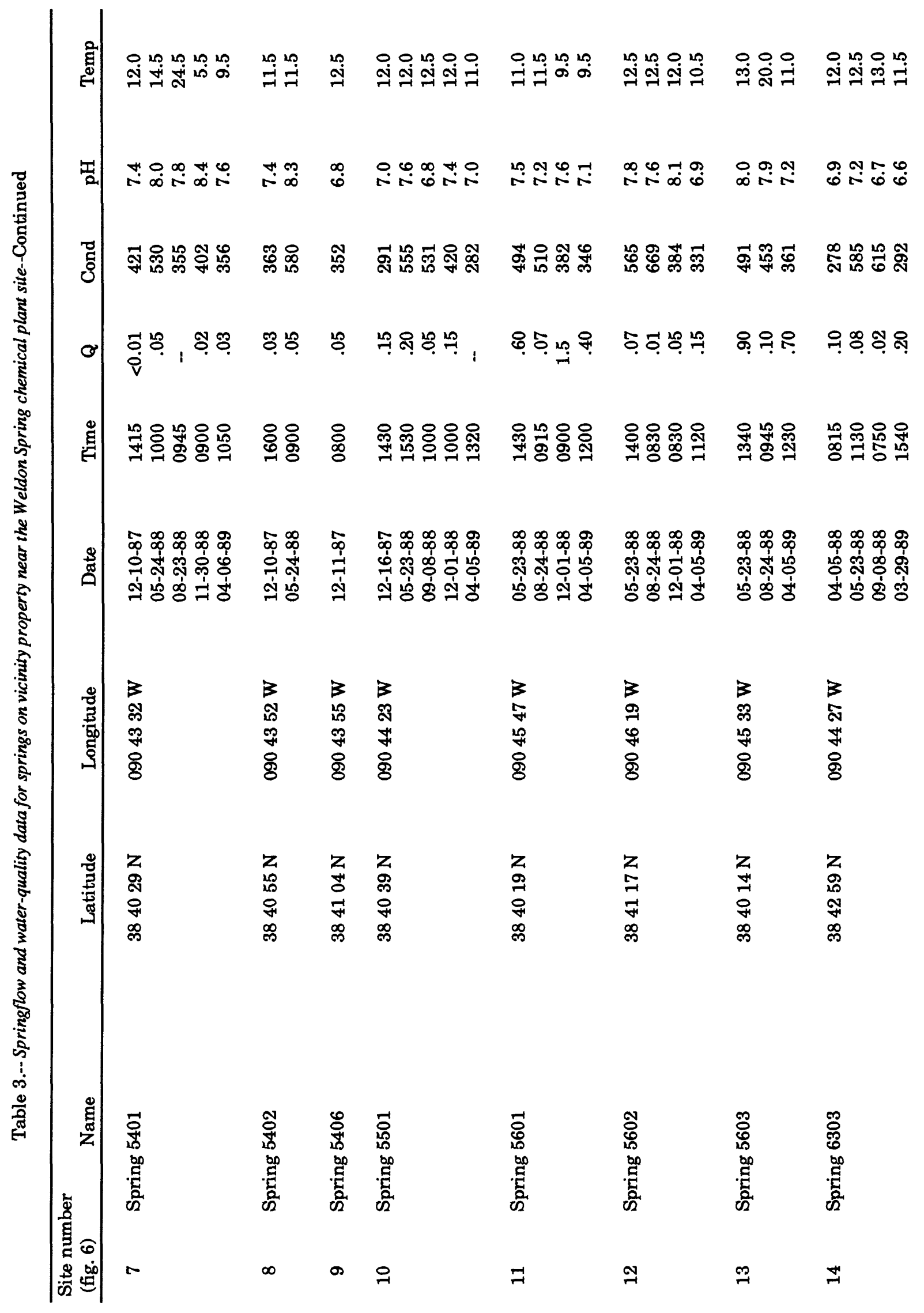




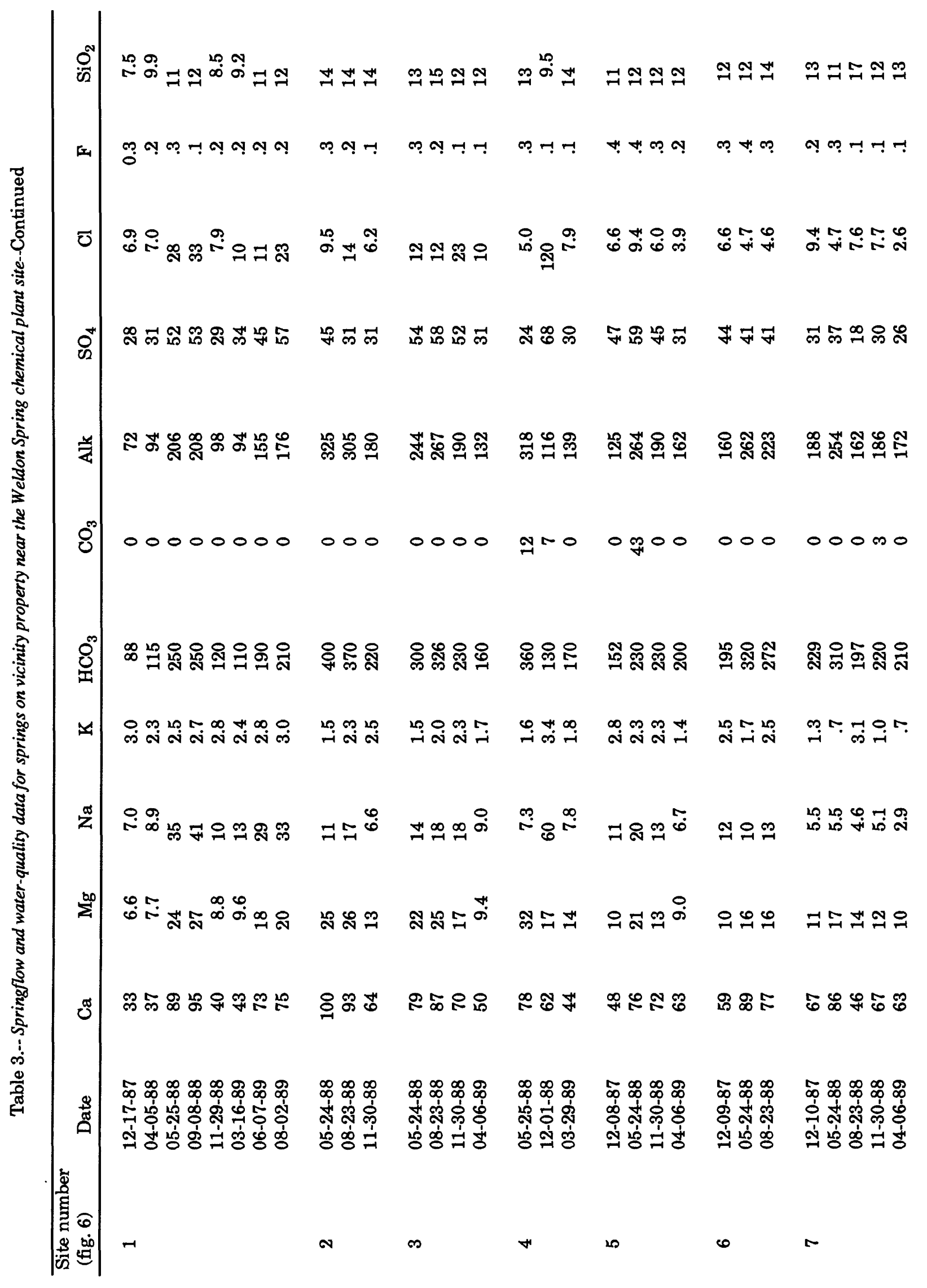




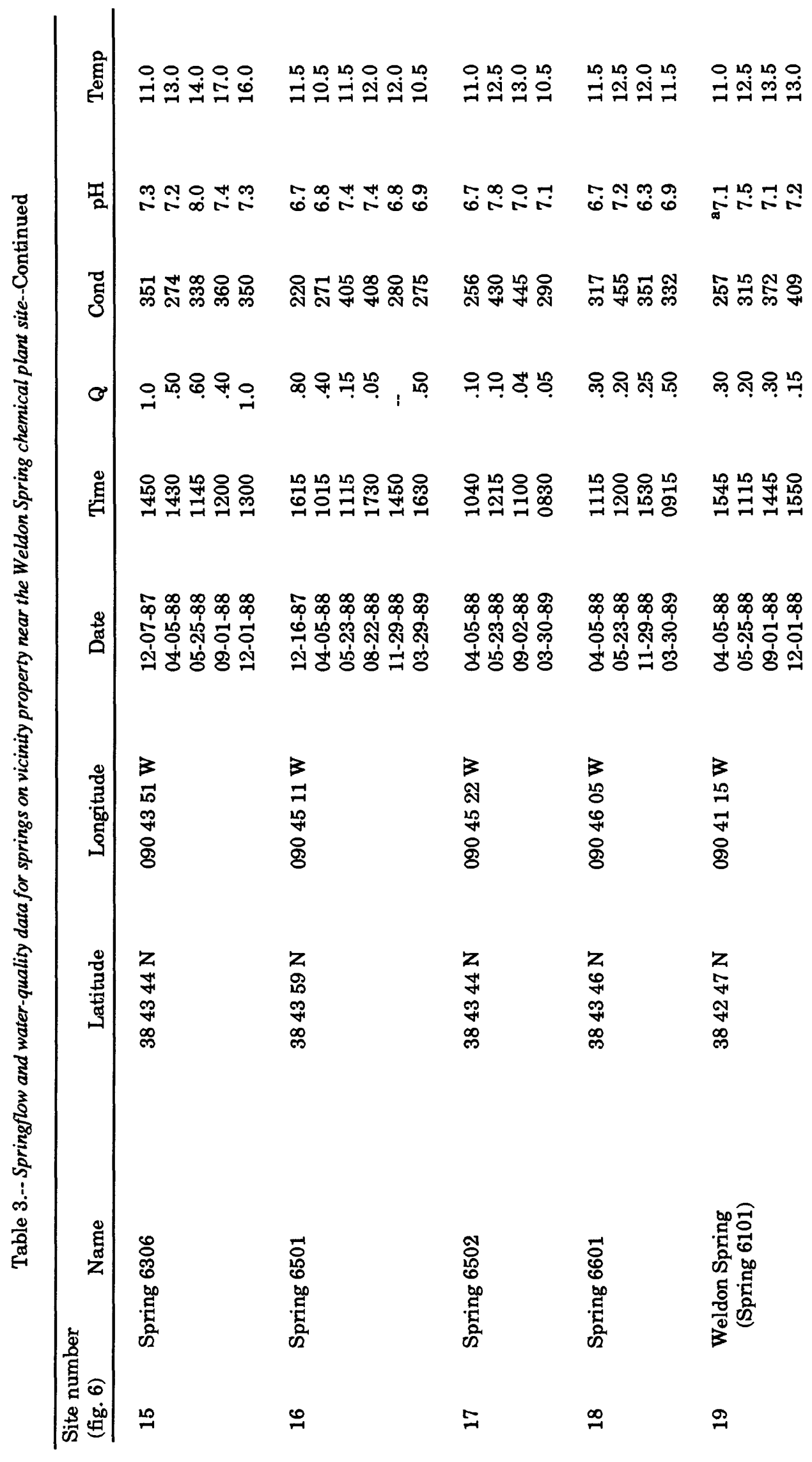




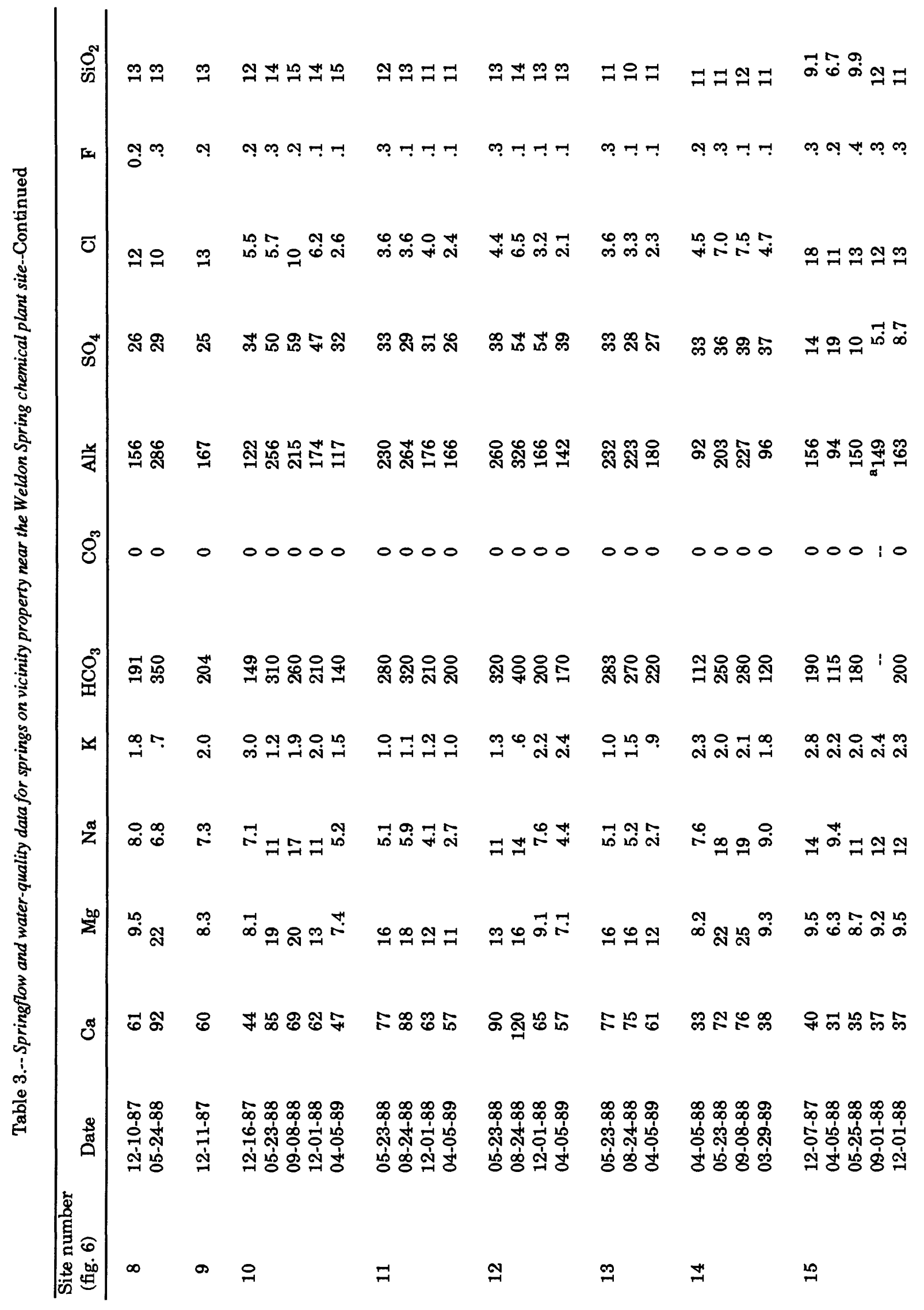




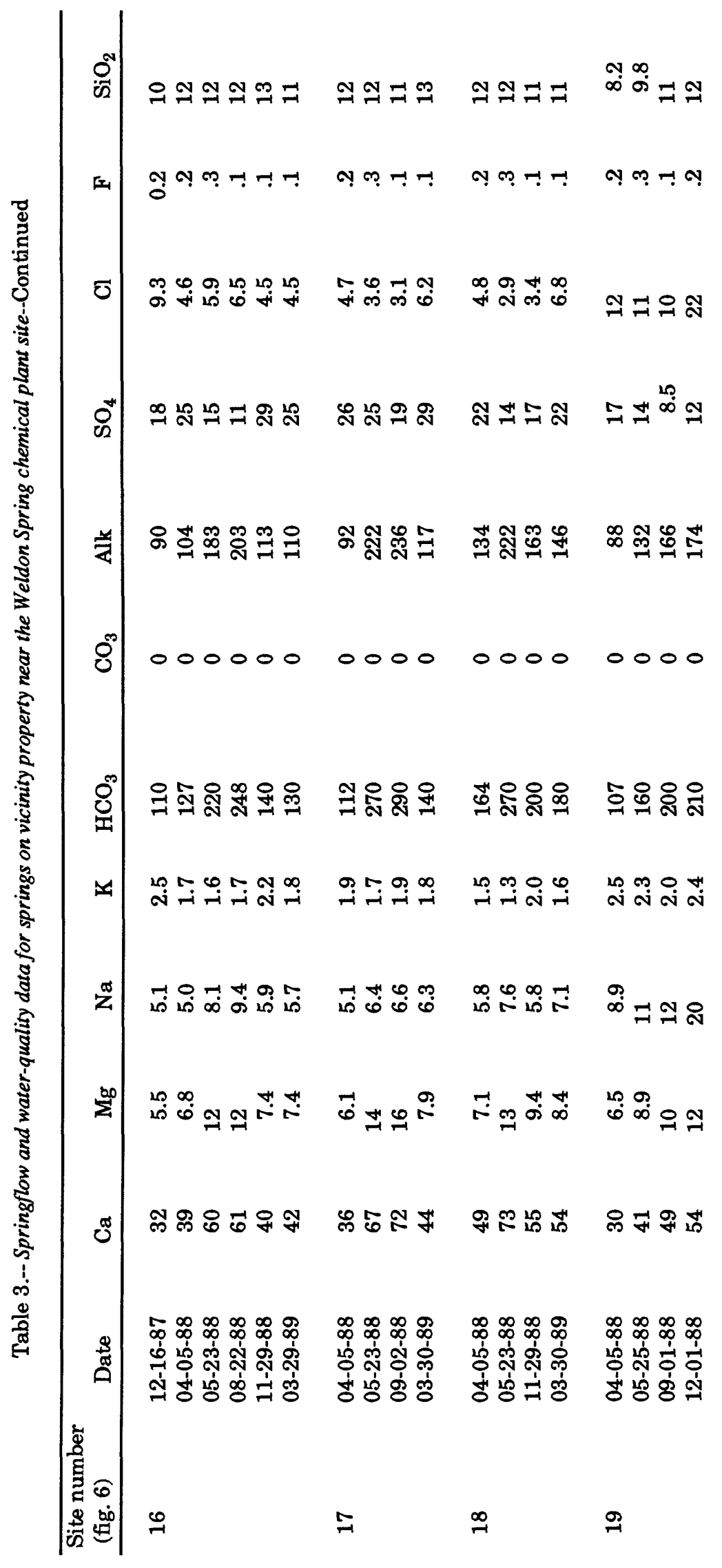




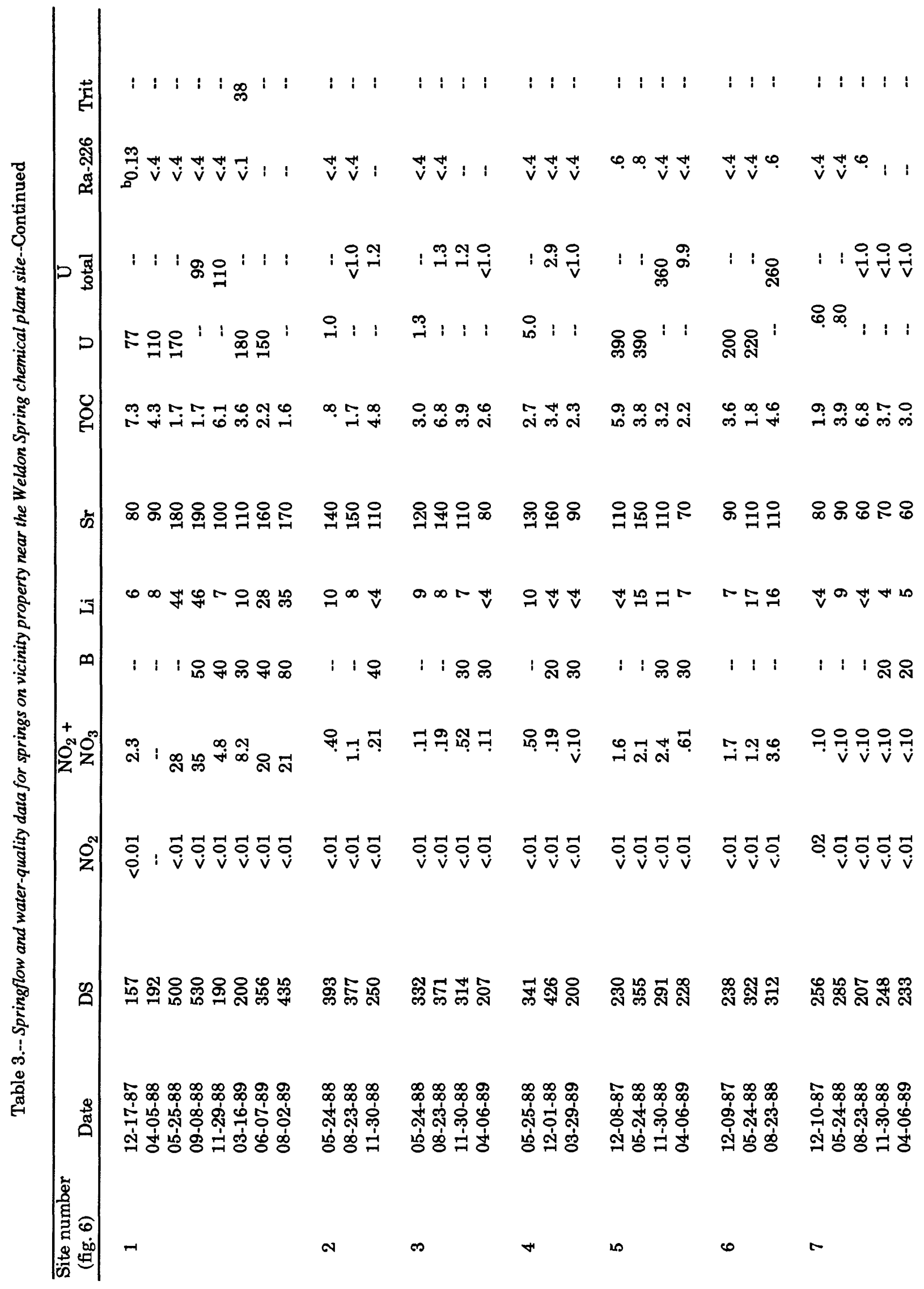




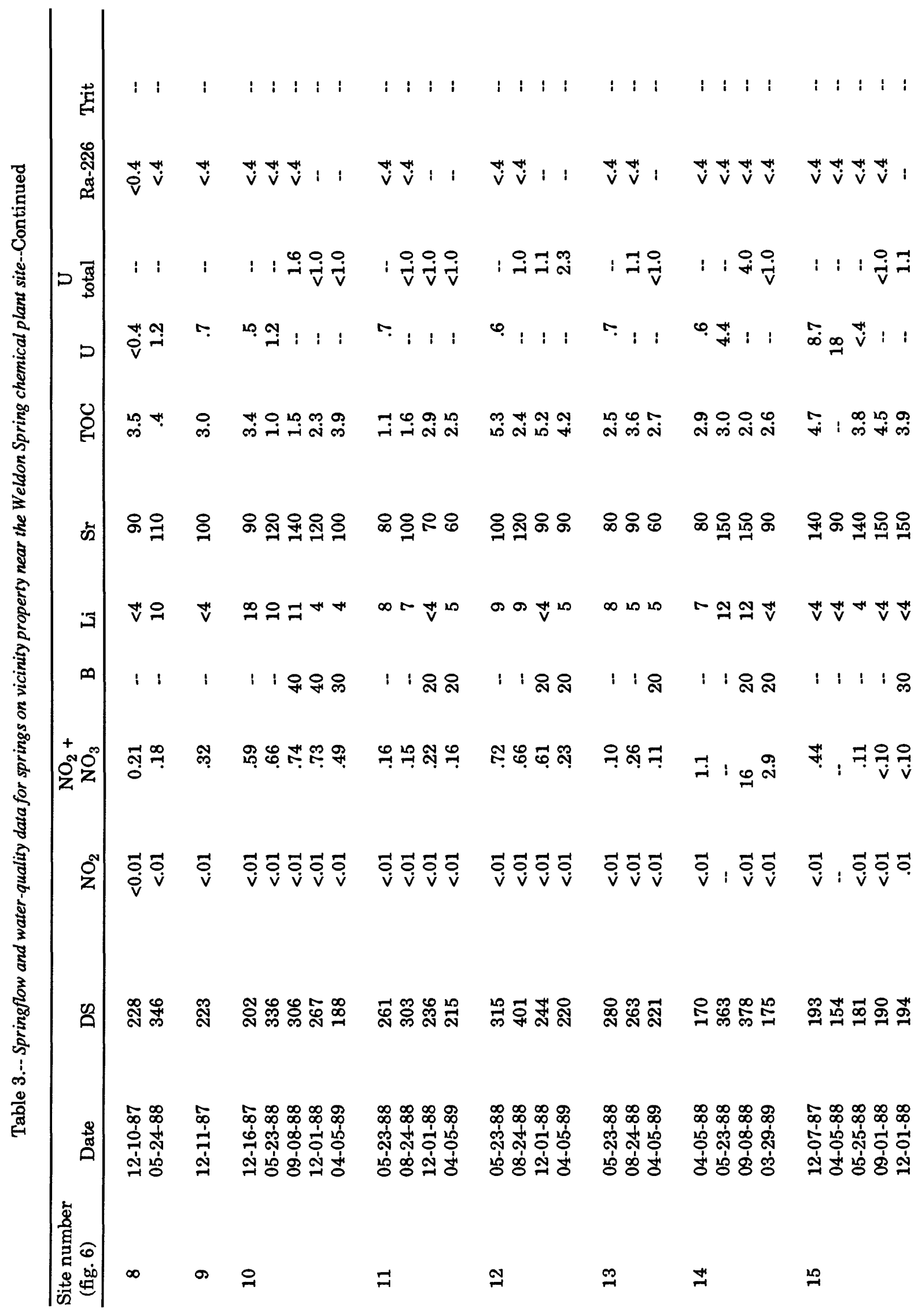




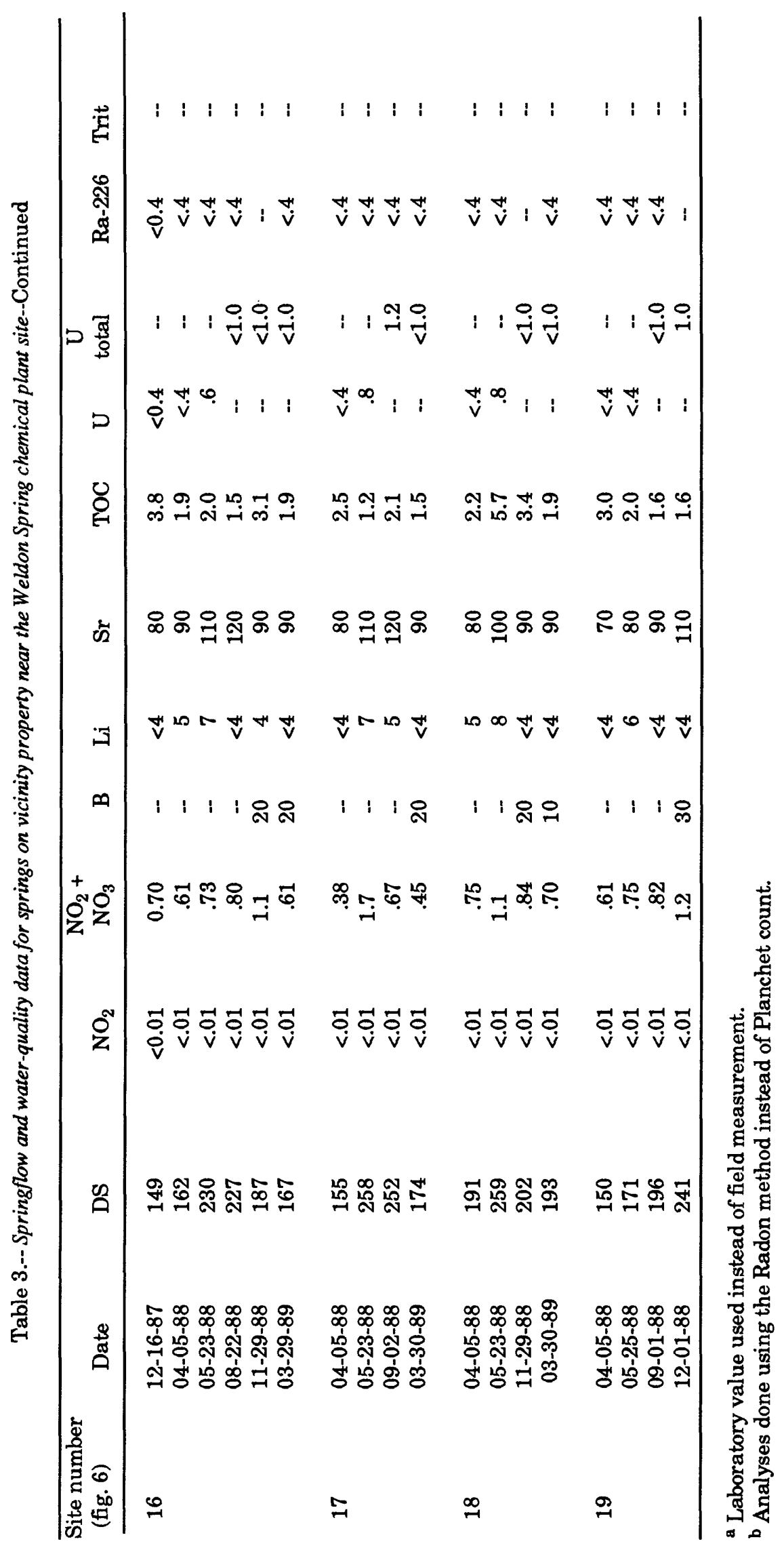




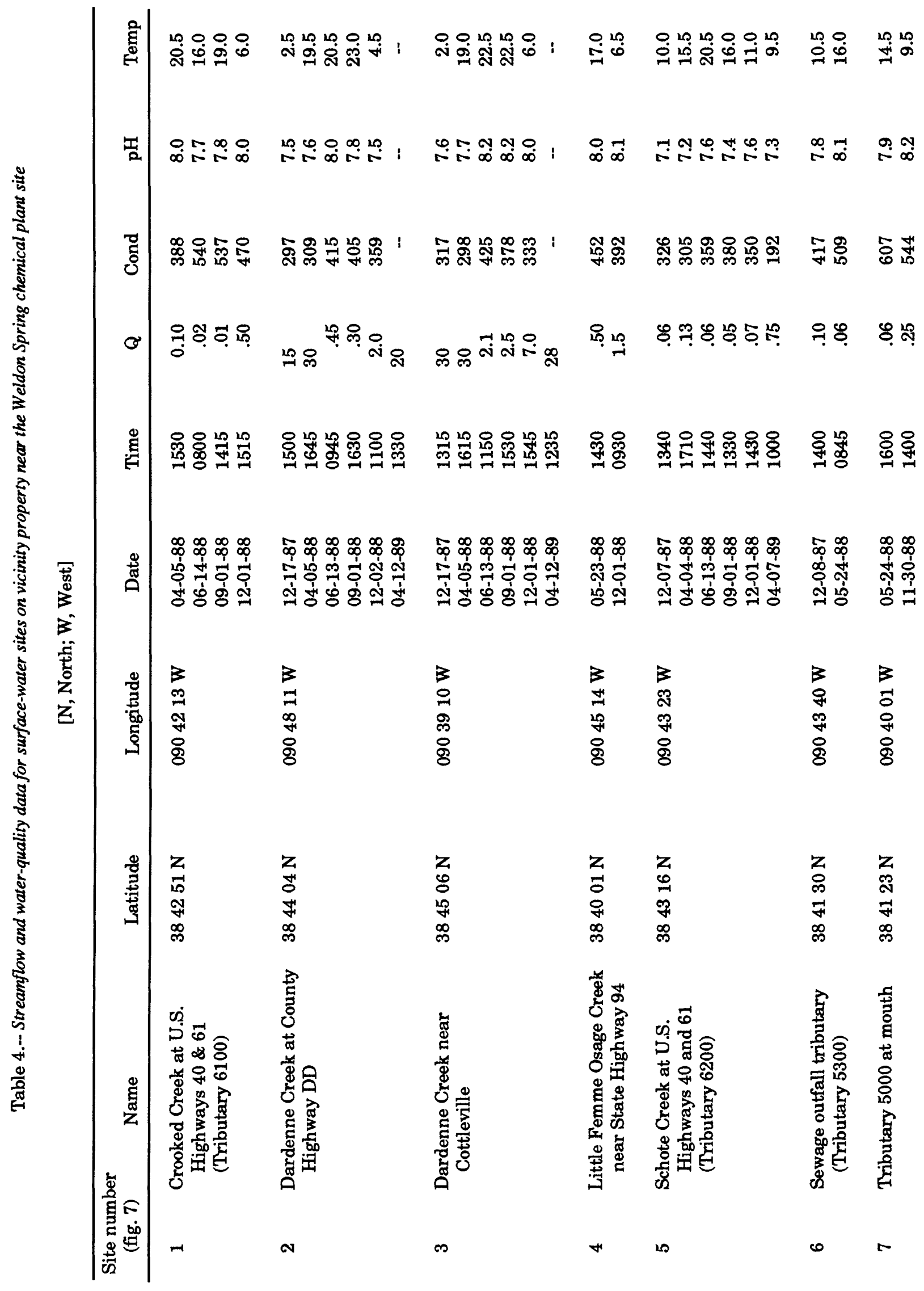




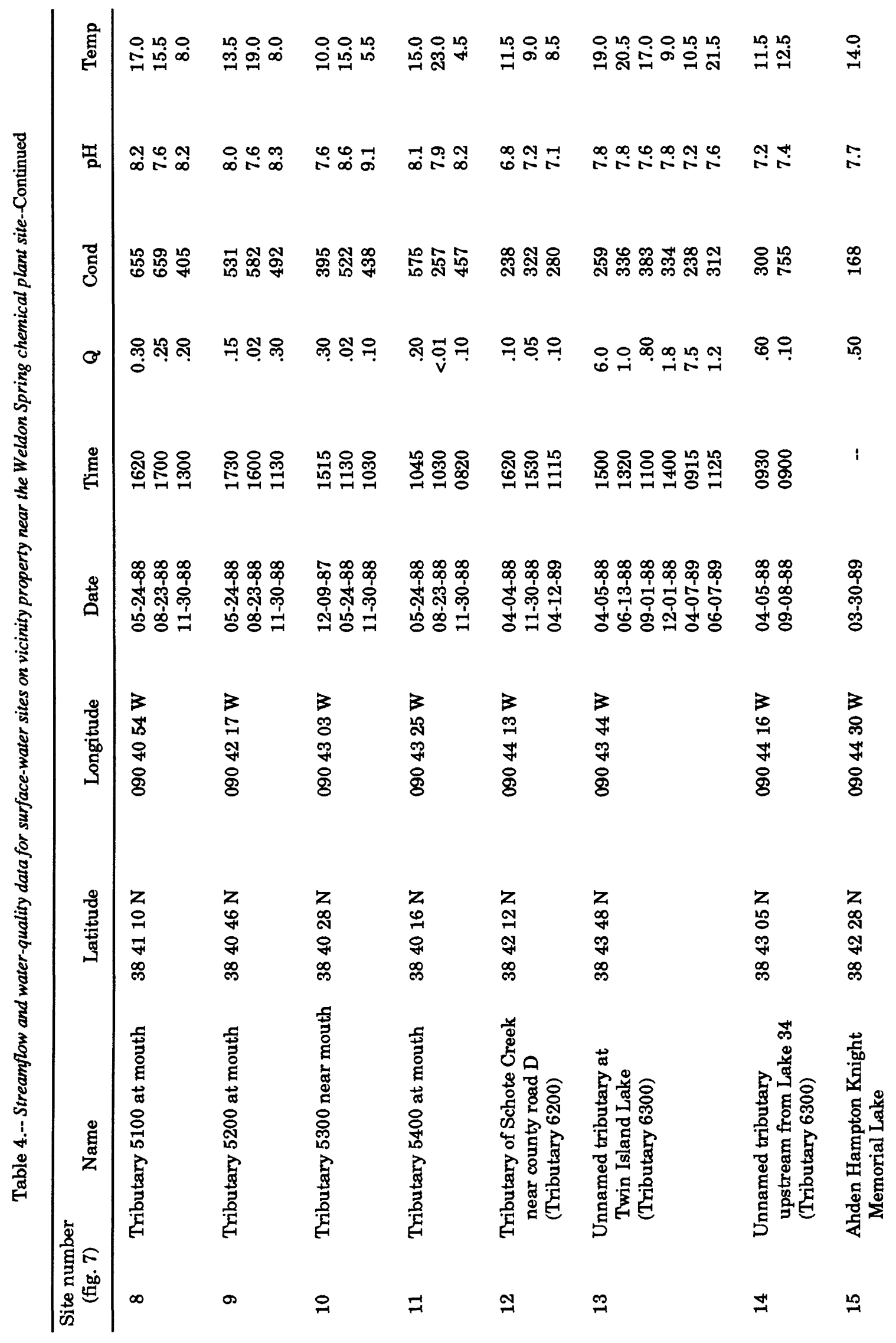




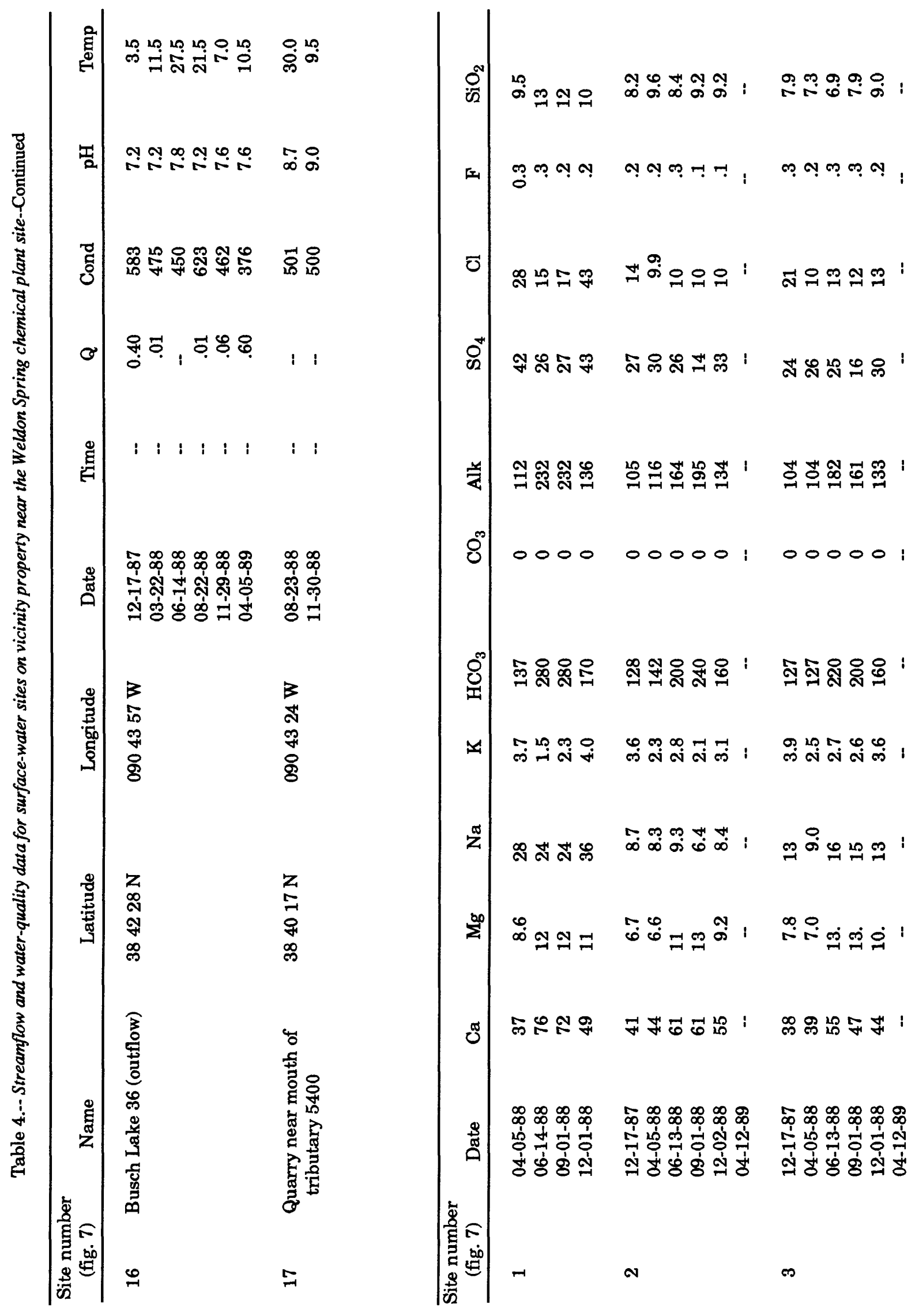




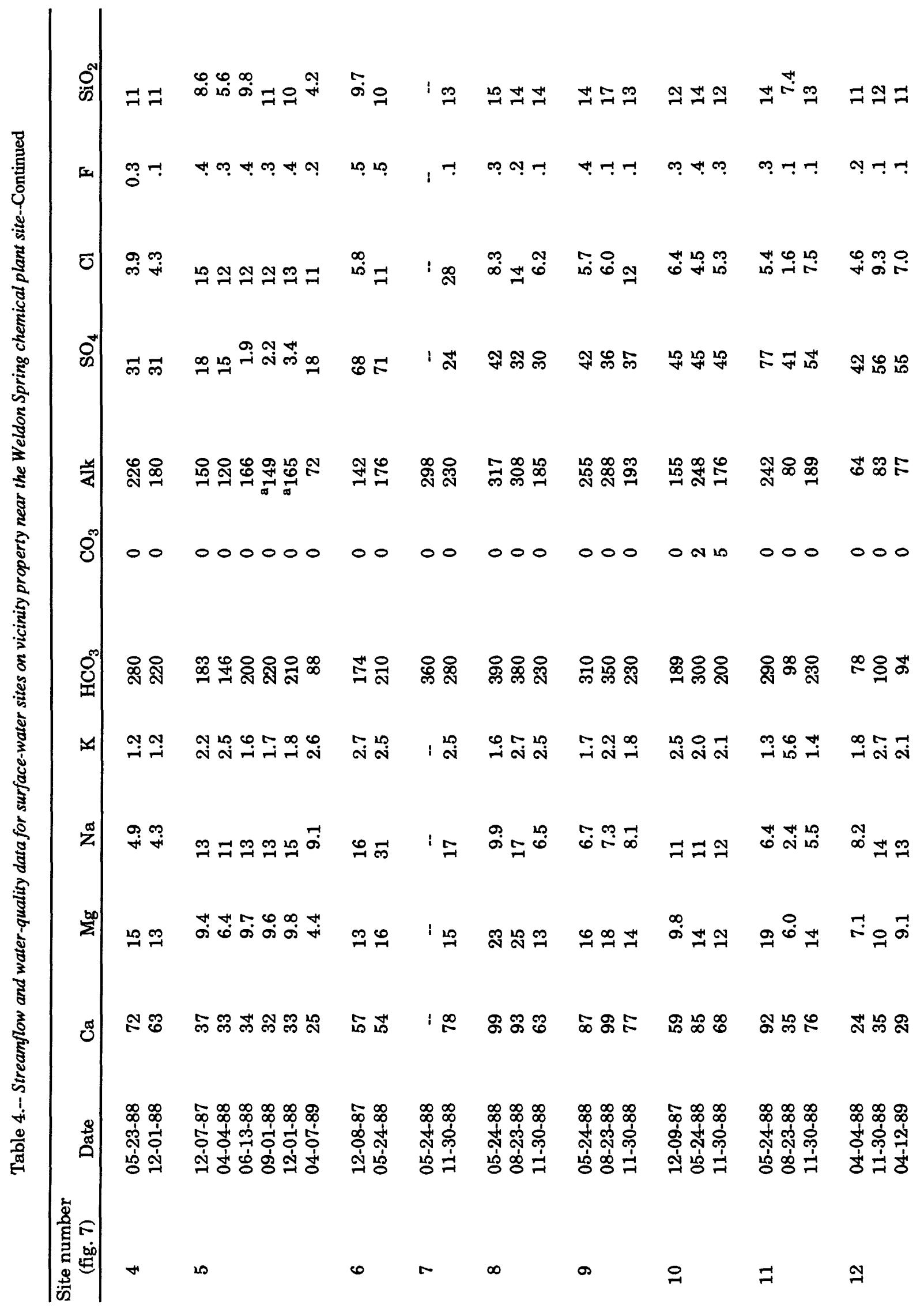




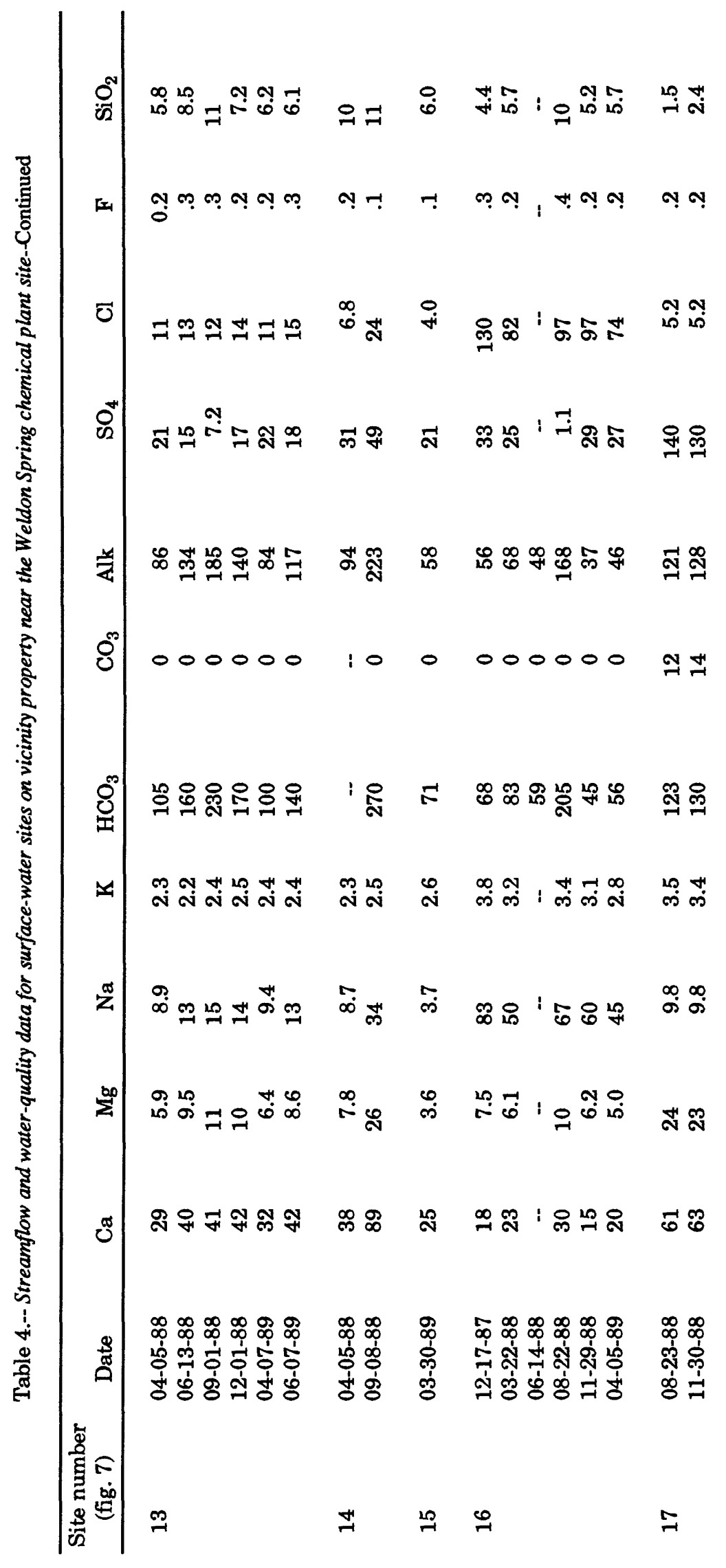




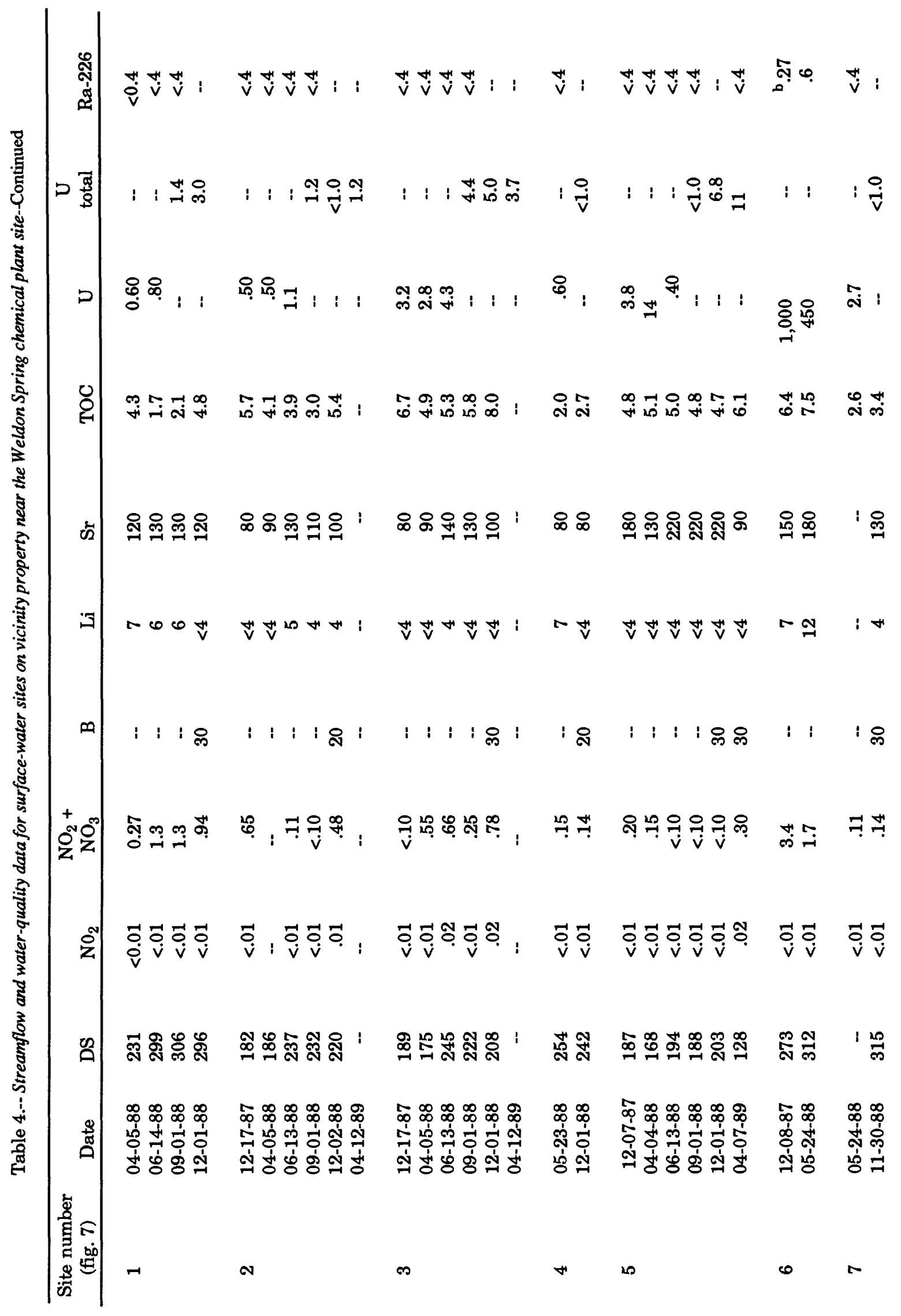




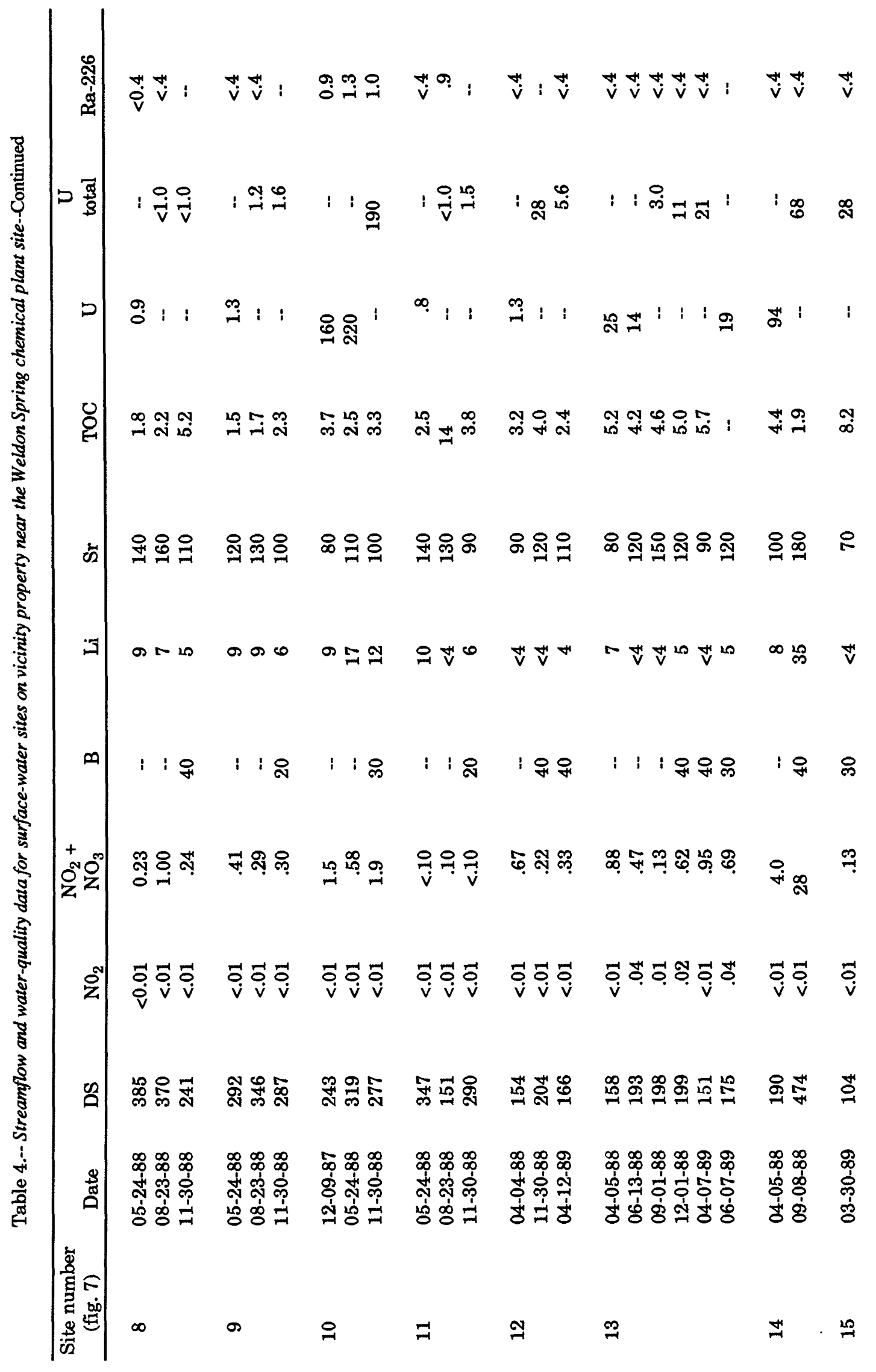




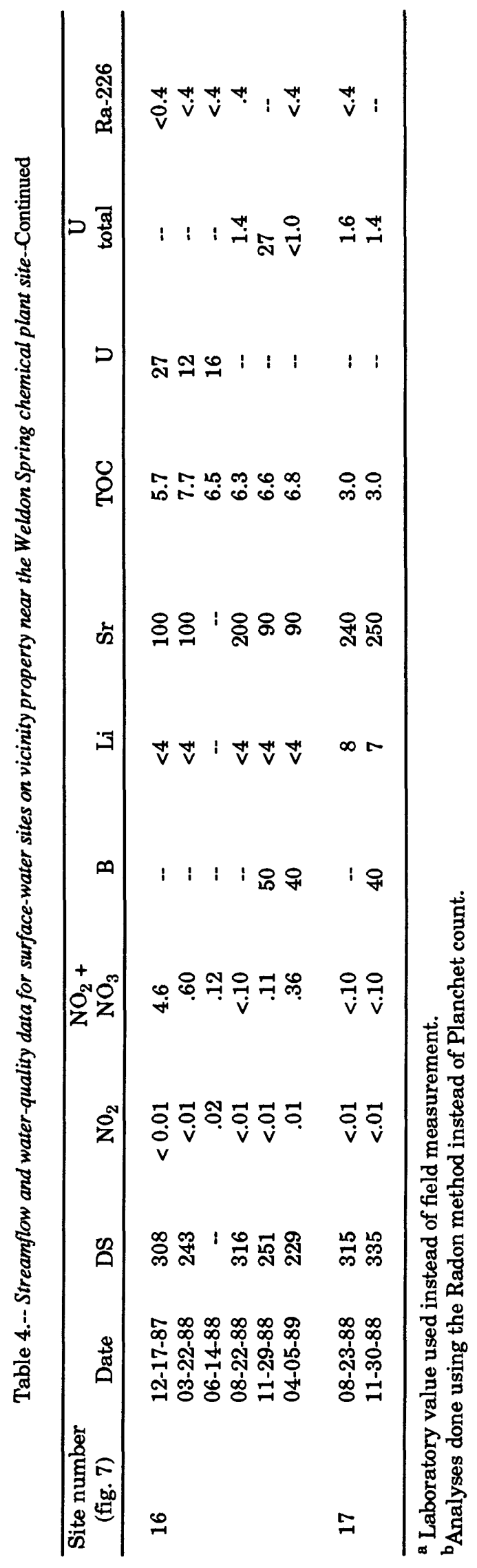




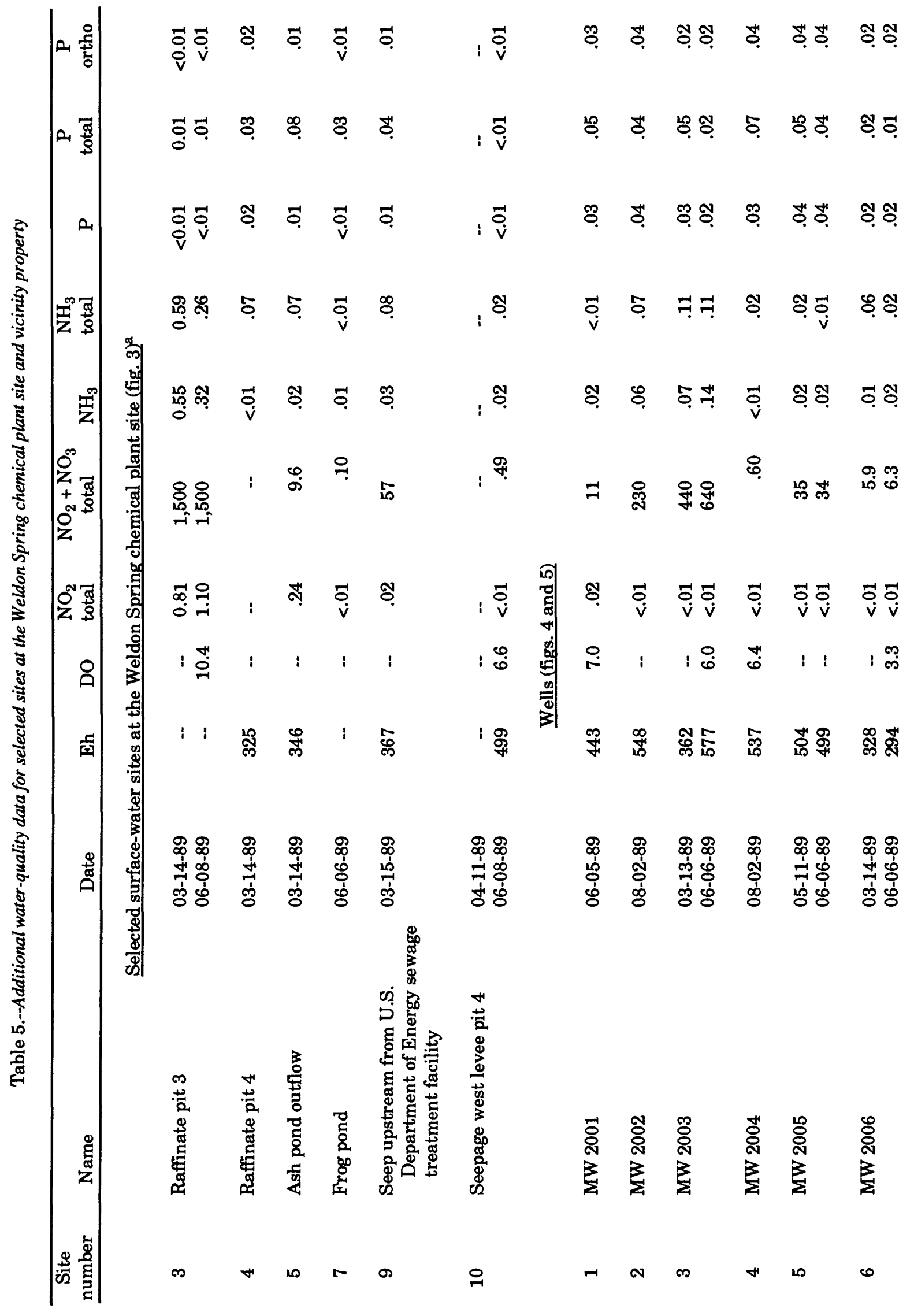




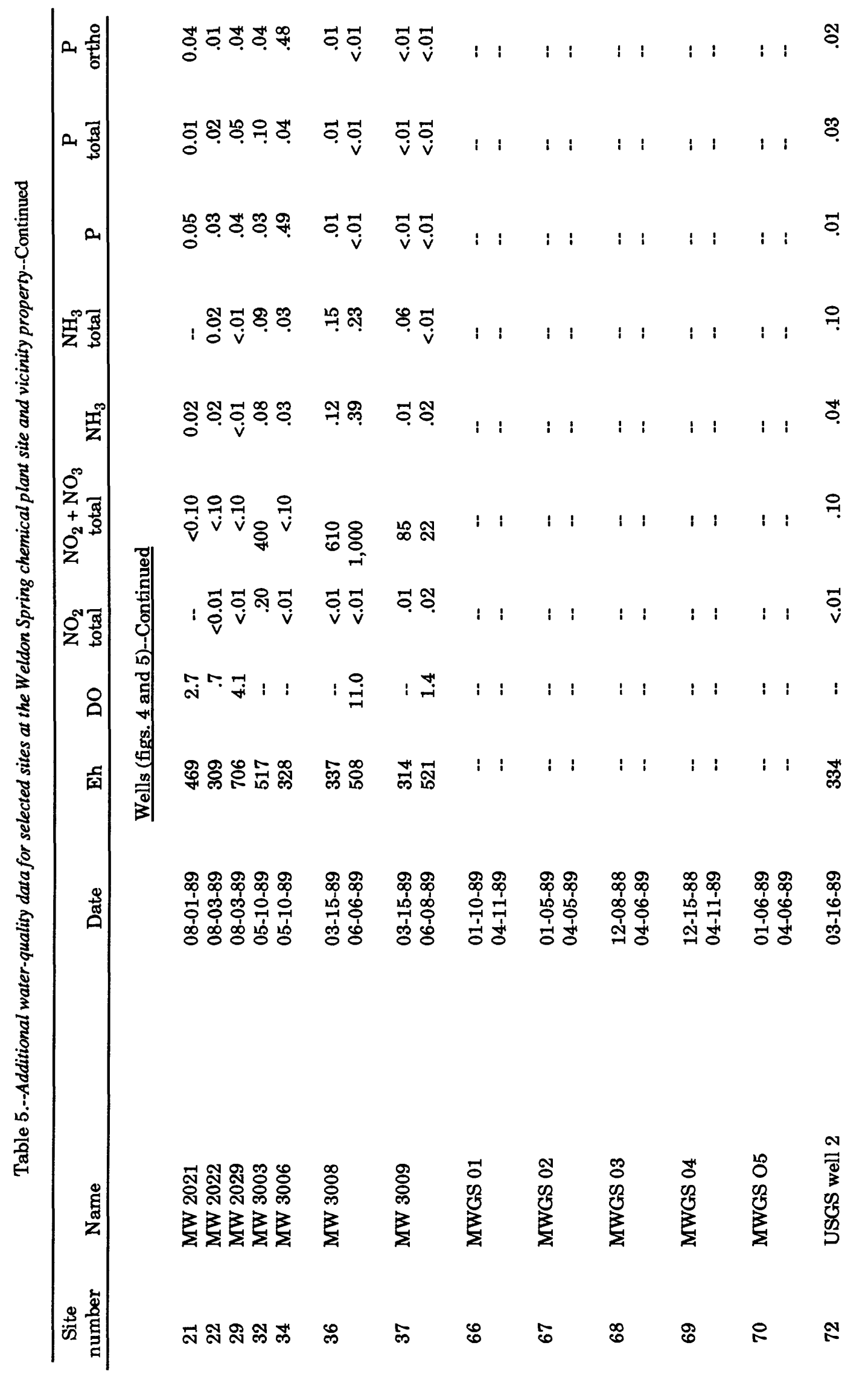




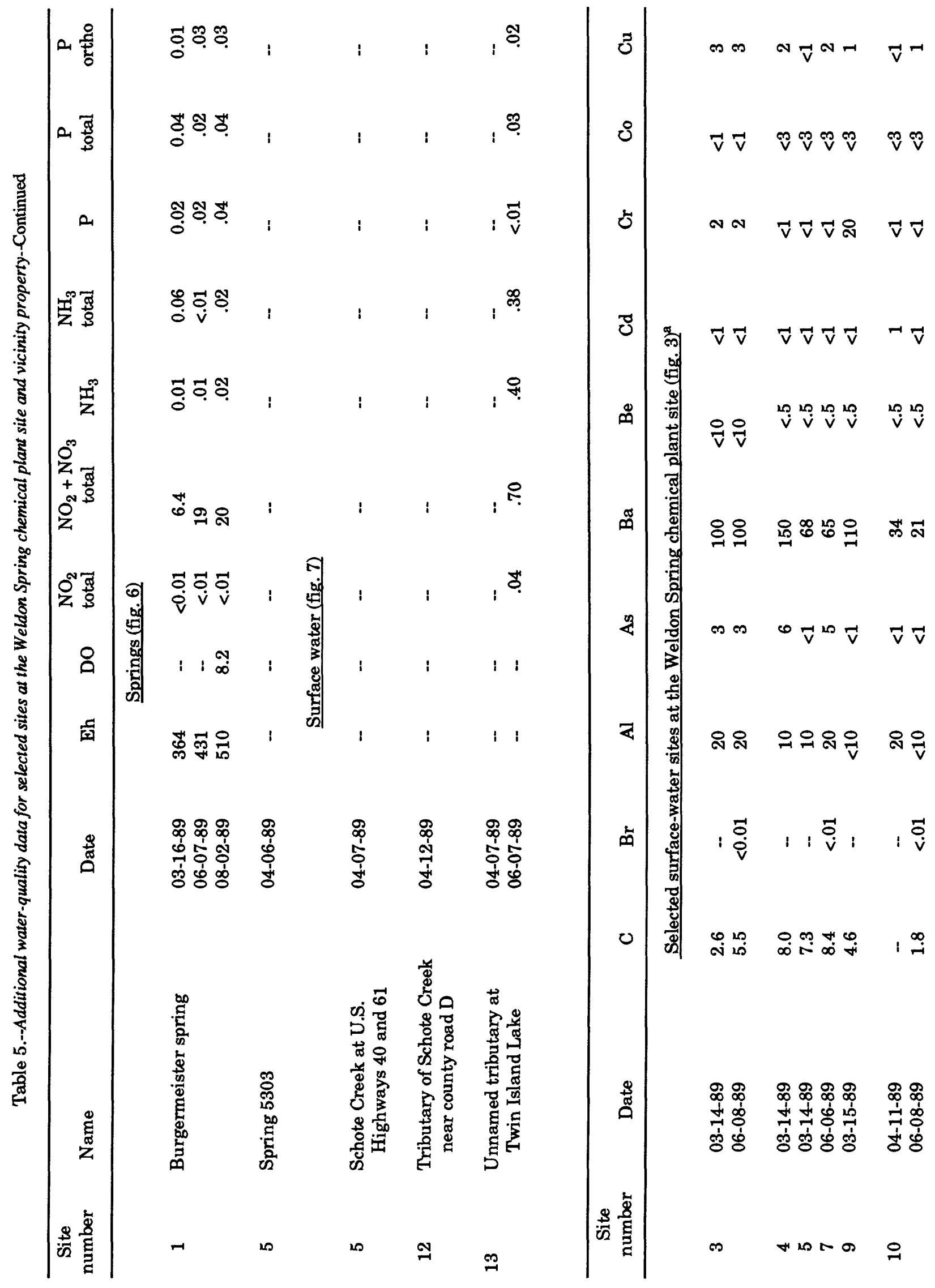




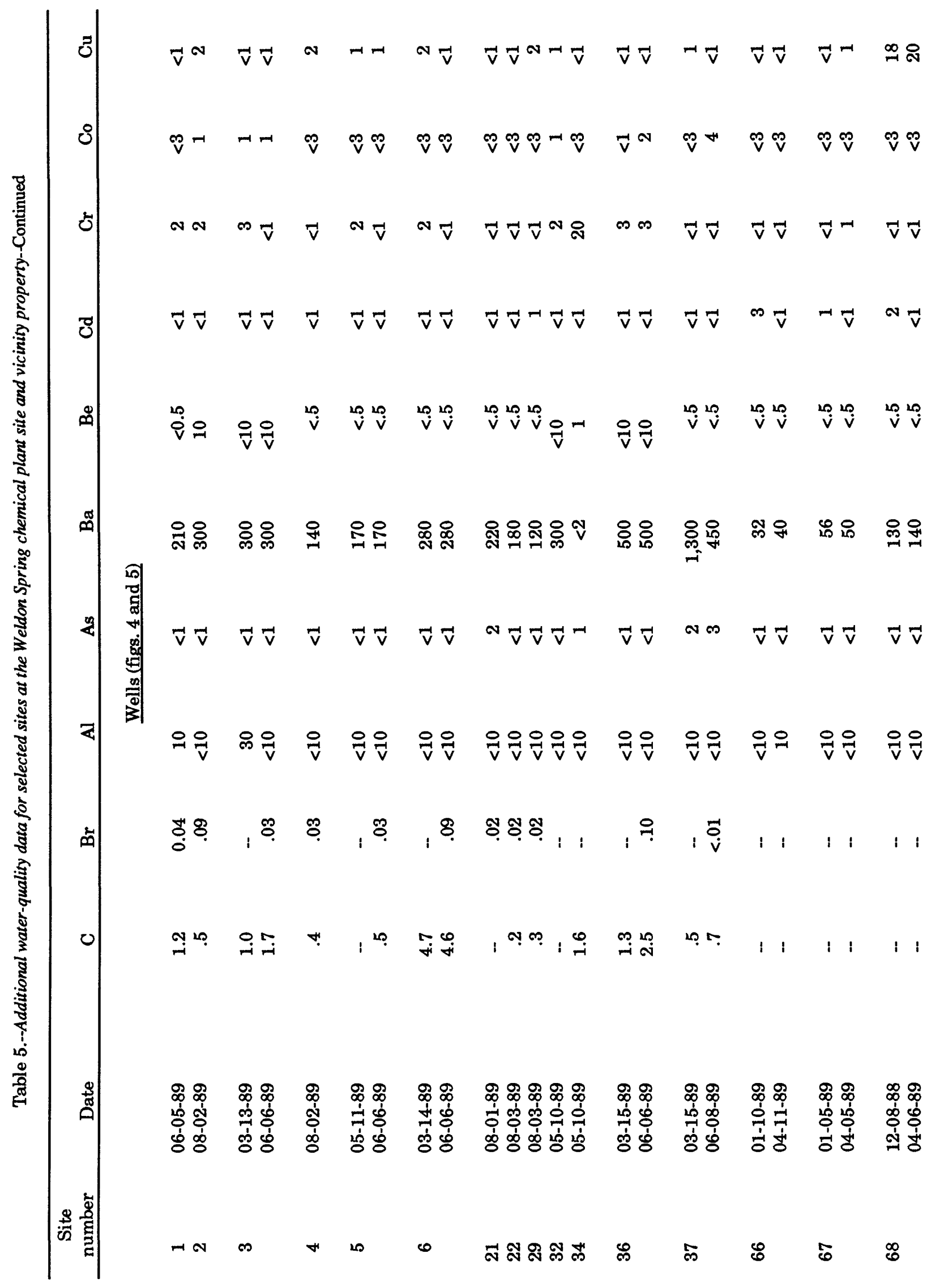




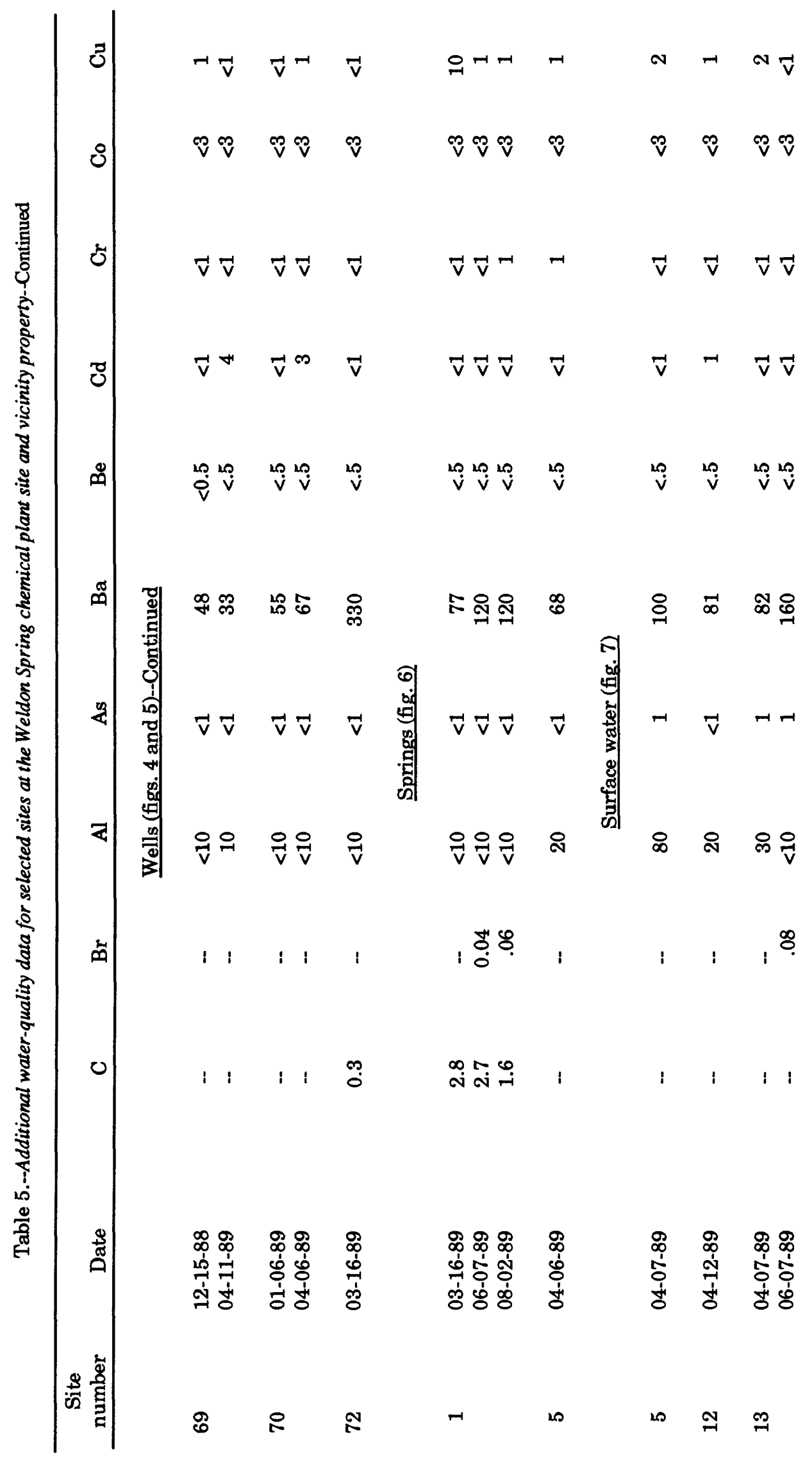




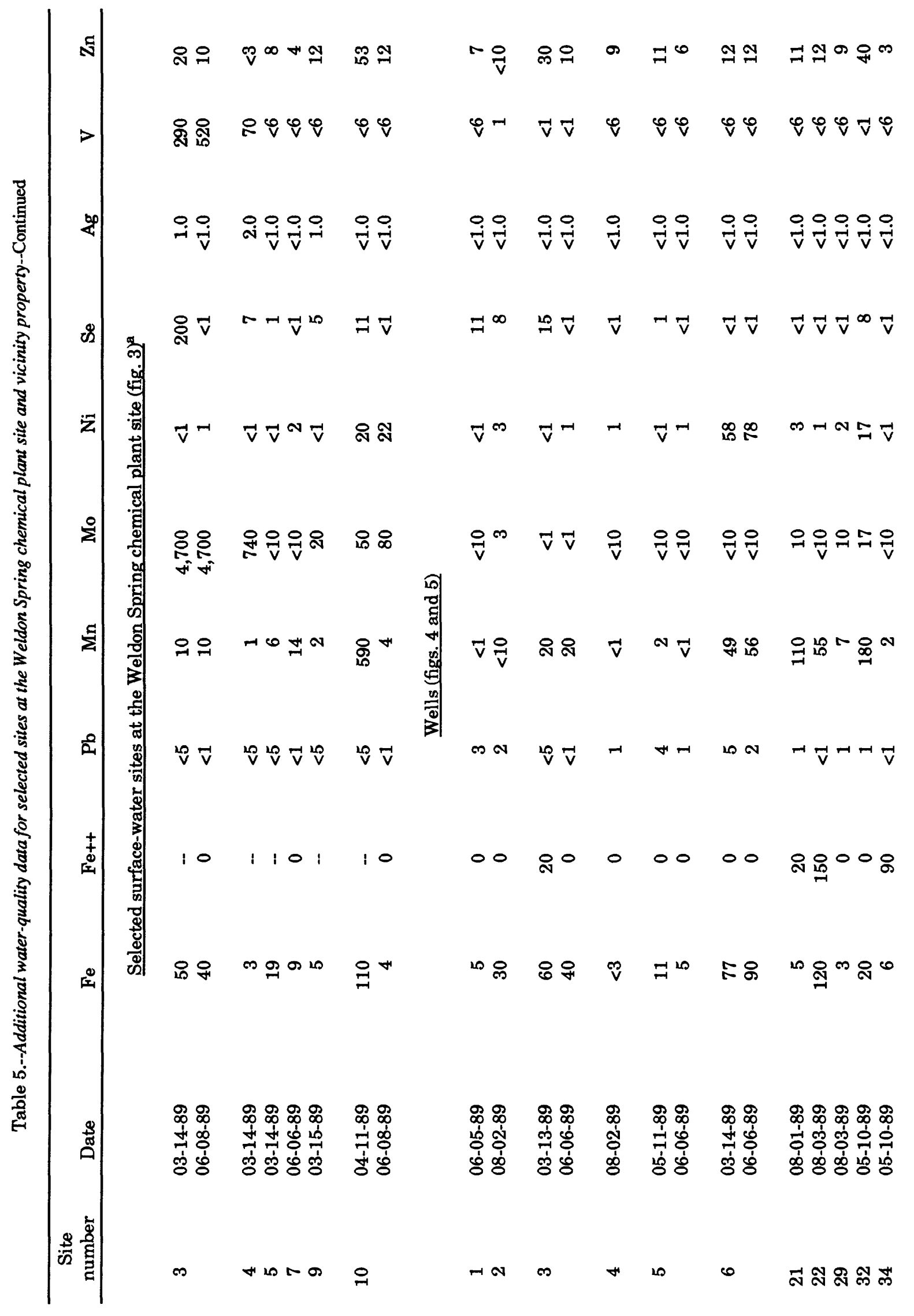




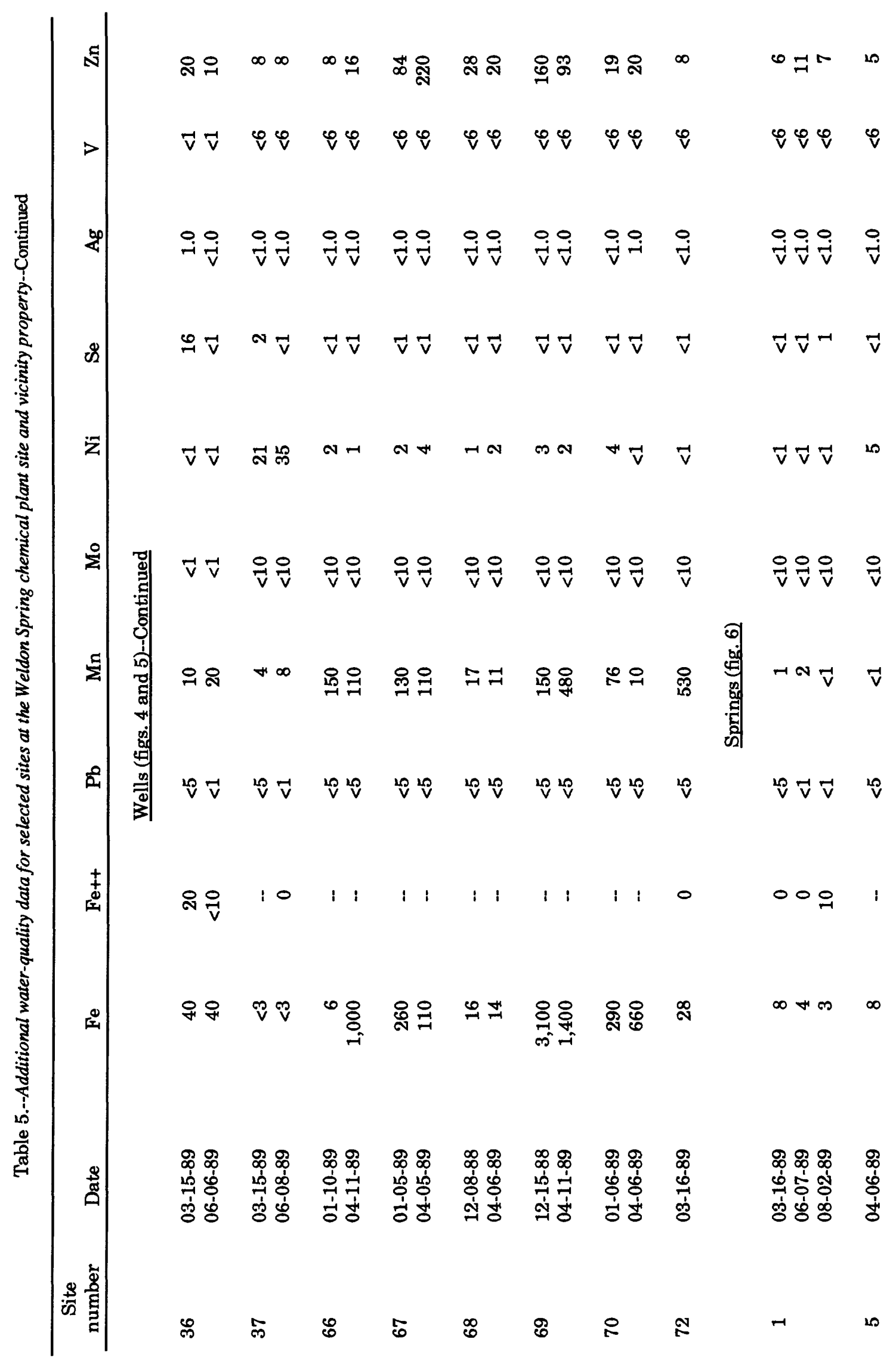




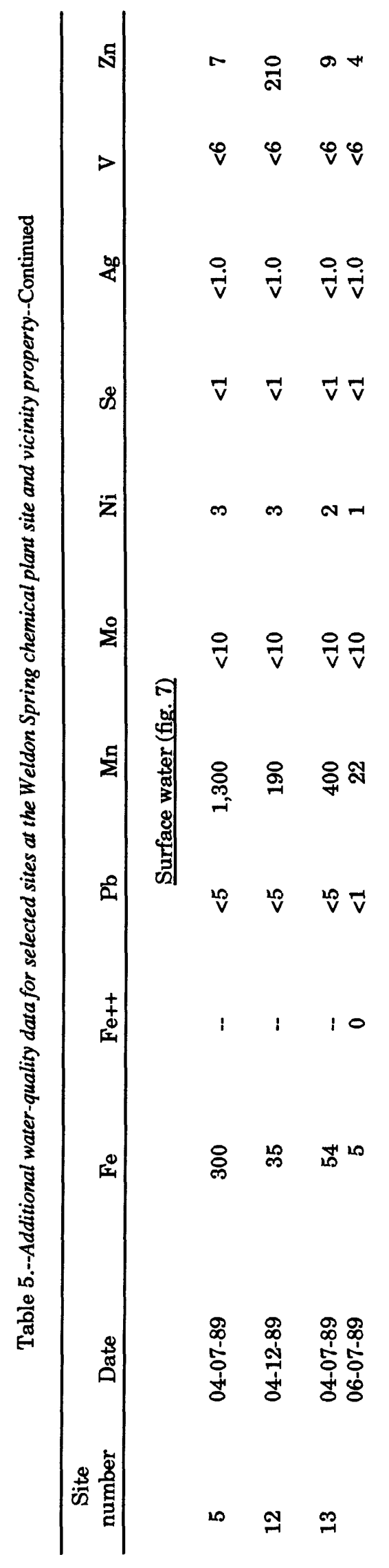




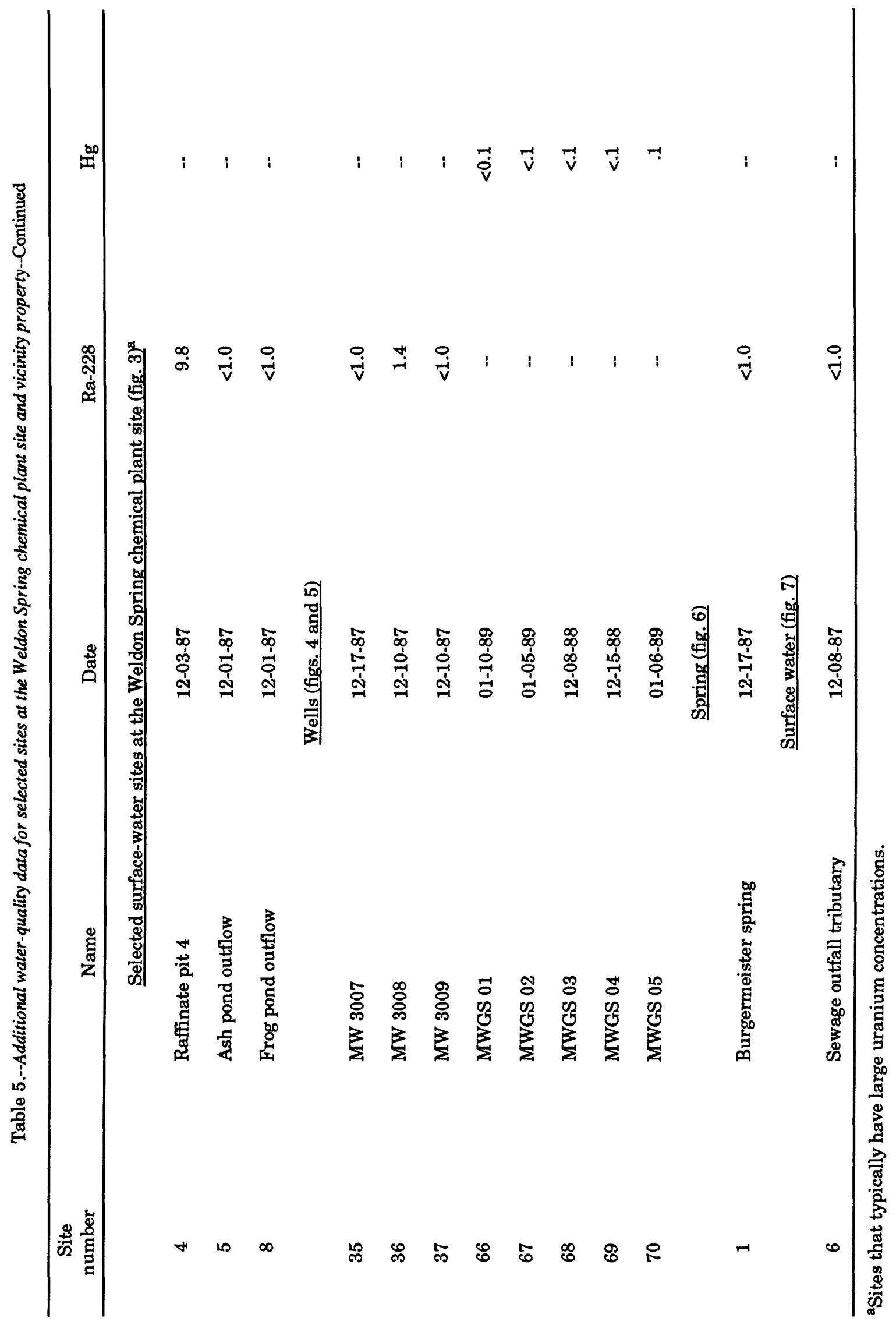




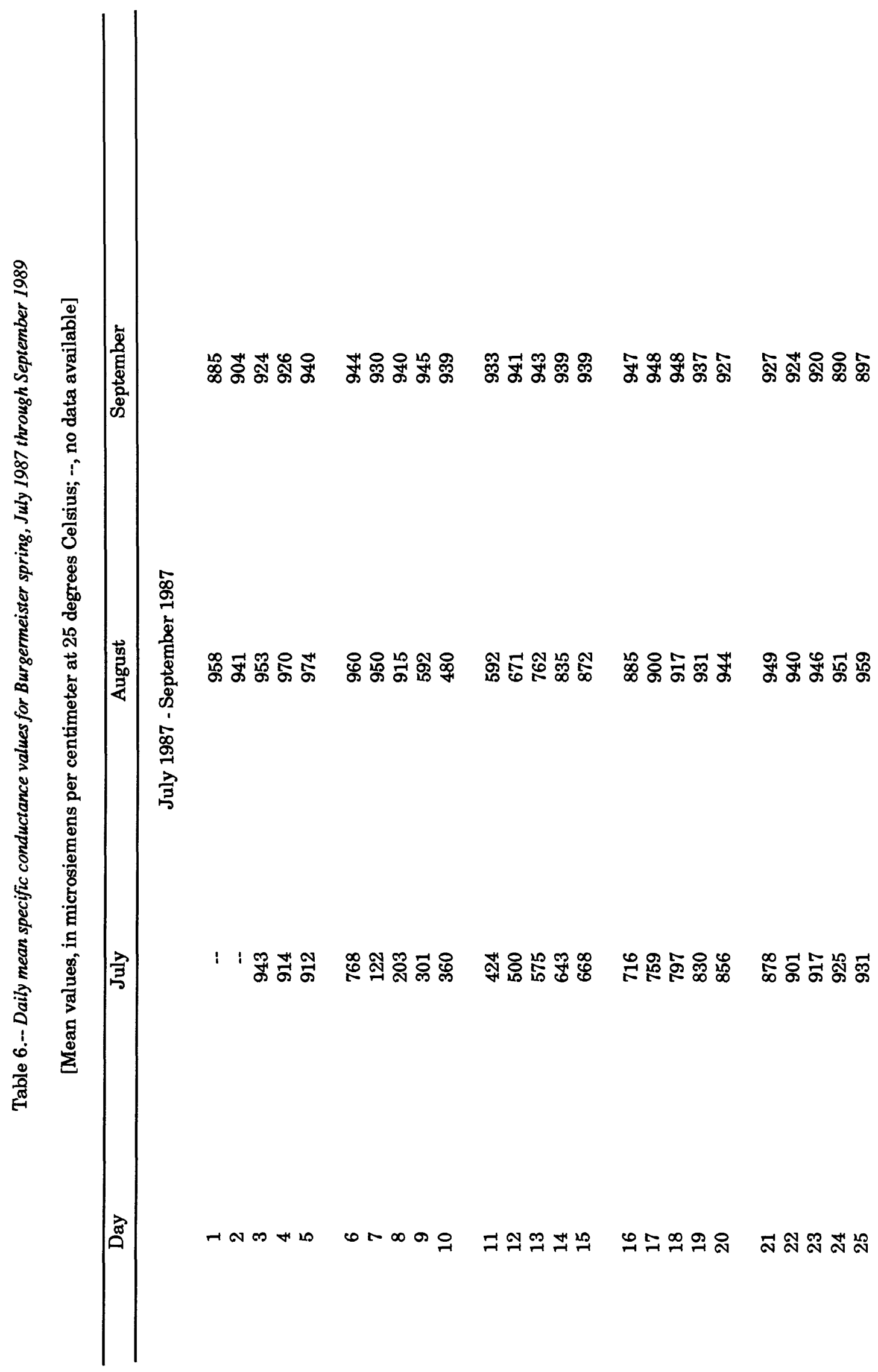




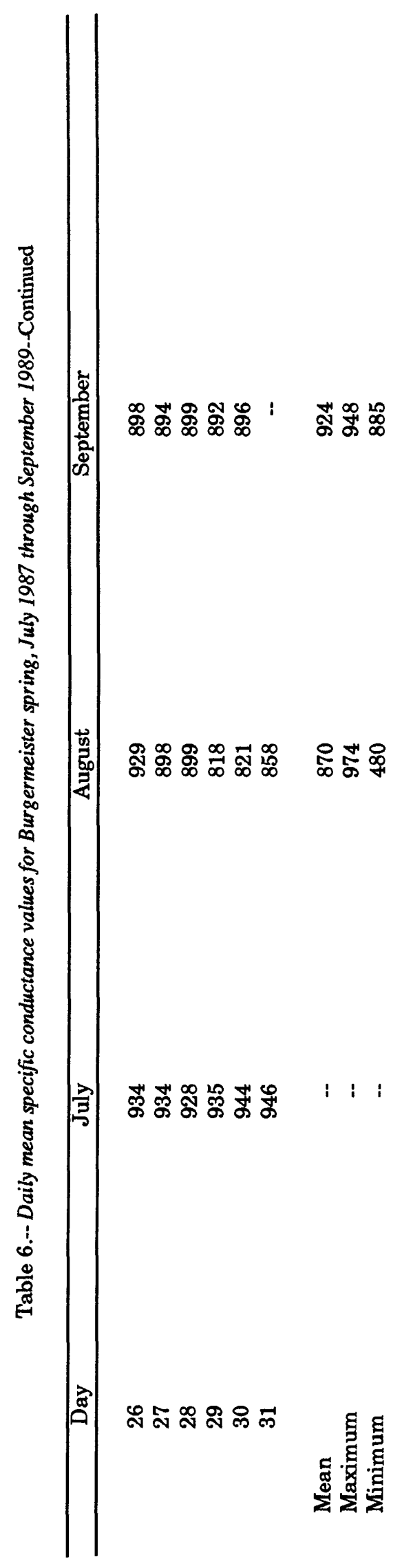




\begin{tabular}{|c|c|c|c|c|c|}
\hline$\left|\begin{array}{c}-1 \\
\vdots \\
0 \\
02\end{array}\right|$ & 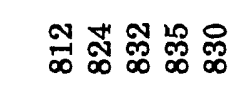 & 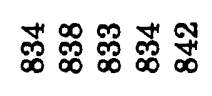 & 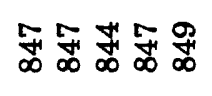 & 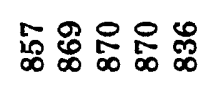 & 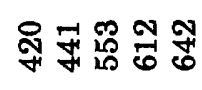 \\
\hline 递 & 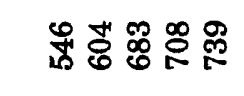 & 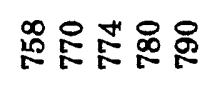 & 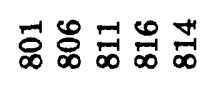 & 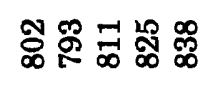 & 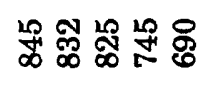 \\
\hline 곡 & 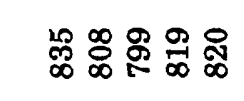 & 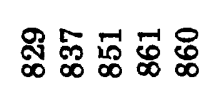 & 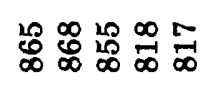 & 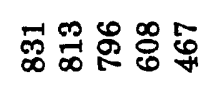 & 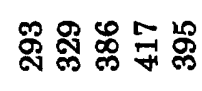 \\
\hline : & 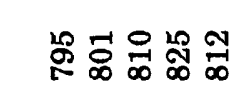 & 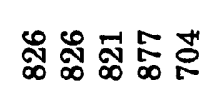 & 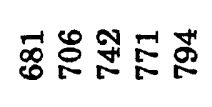 & 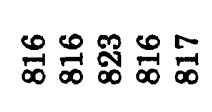 & 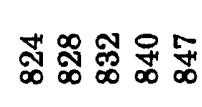 \\
\hline $\mid$ & 赵: & 路赵总品品 & 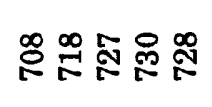 & 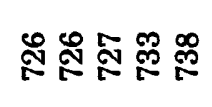 & 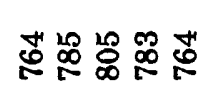 \\
\hline 安 & 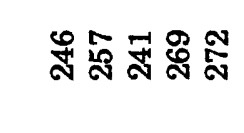 & 중워 & 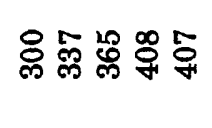 & 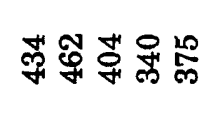 & 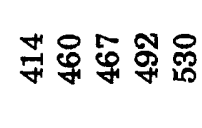 \\
\hline$\dot{\vec{m}}$ & 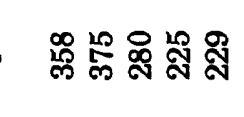 & 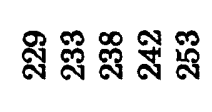 & 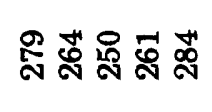 & 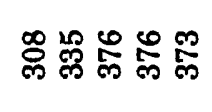 & 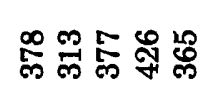 \\
\hline 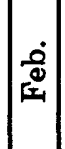 & 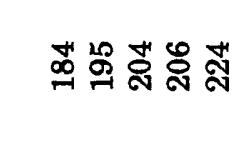 & 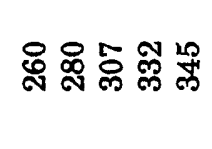 & 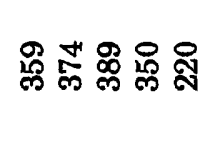 & 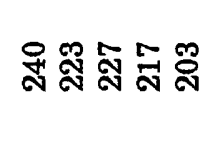 & 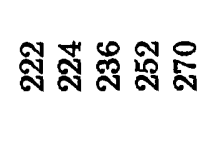 \\
\hline 岀 & 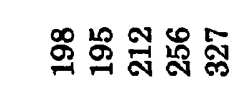 & 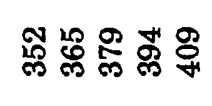 & 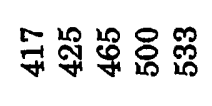 & 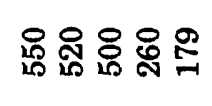 & 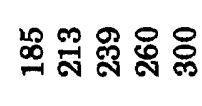 \\
\hline : & 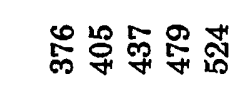 & 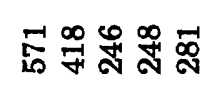 & 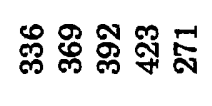 & 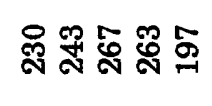 & 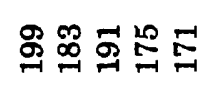 \\
\hline 芸 & 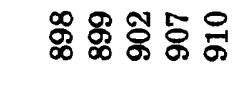 & 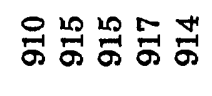 & 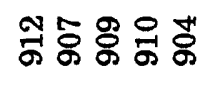 & 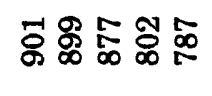 & 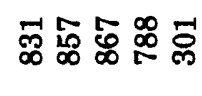 \\
\hline : & 胥 & 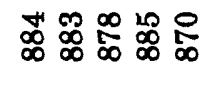 & 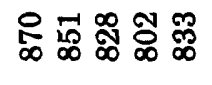 & 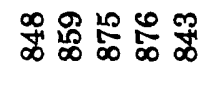 & 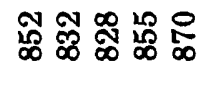 \\
\hline 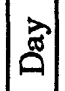 & $-\infty$ & 요 & 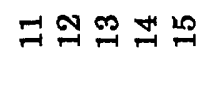 & 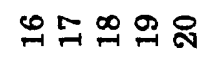 & ন \\
\hline
\end{tabular}




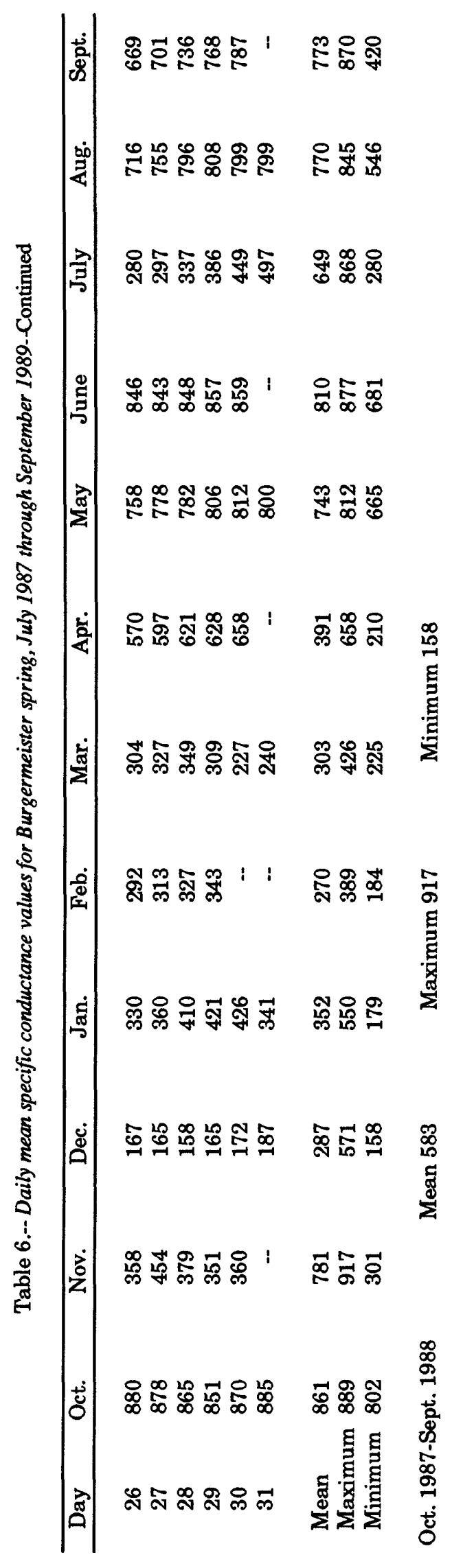




\begin{tabular}{|c|c|c|c|c|c|}
\hline 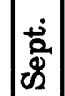 & 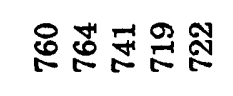 & 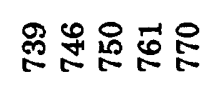 & 동옹토영 & 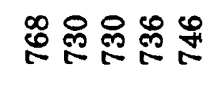 & 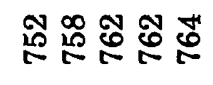 \\
\hline$\left|\frac{\dot{b}}{2}\right|$ & 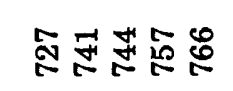 & 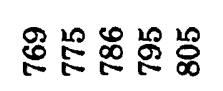 & 必 & 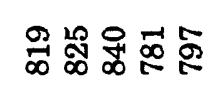 & 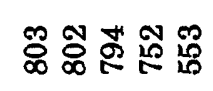 \\
\hline 穹 & 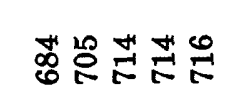 & 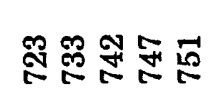 & 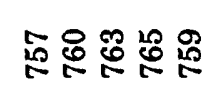 & 央 & 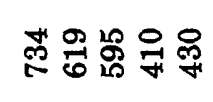 \\
\hline 号 & 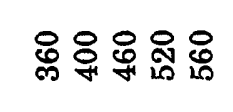 & శ్రి:용: & 양웅옹유윻 & ్ㅗㅇ & 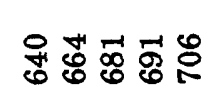 \\
\hline 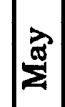 & 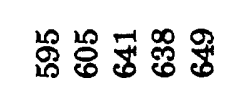 & 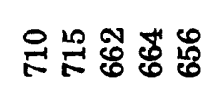 & : & : & 잉영형용융 \\
\hline $\mid$ & 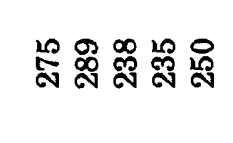 & 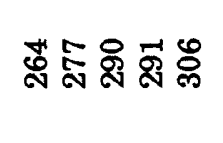 & 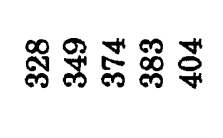 & 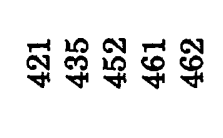 & 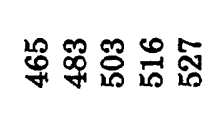 \\
\hline $\mid$ & 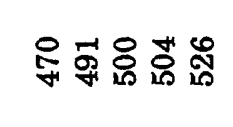 & 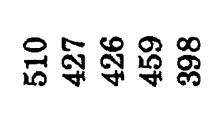 & 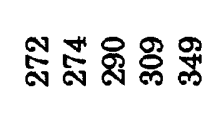 & 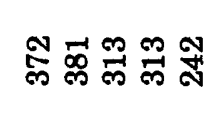 & 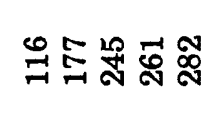 \\
\hline 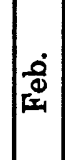 & 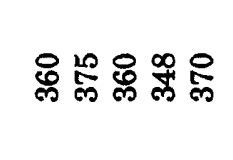 & 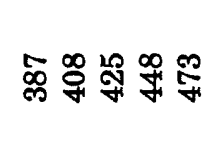 & 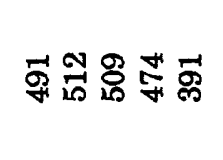 & 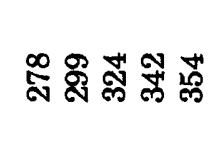 & 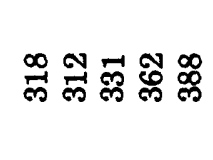 \\
\hline 崈 & 암윰영영요 & 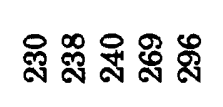 & 잍 & 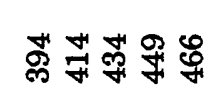 & 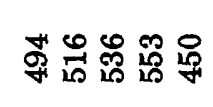 \\
\hline$\dot{\dot{g}}$ & 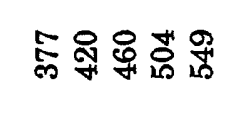 & 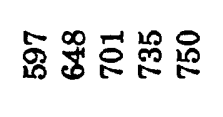 & 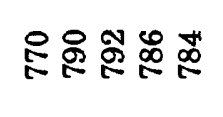 & 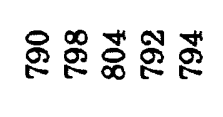 & 象哭品 \\
\hline$\dot{0}$ & 초옹용요 & 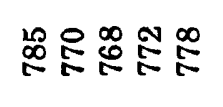 & 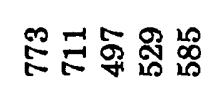 & 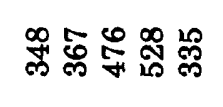 & 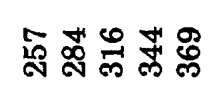 \\
\hline : & 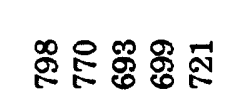 & 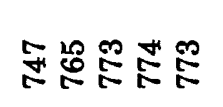 & 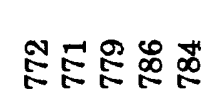 & 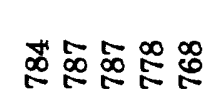 & 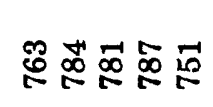 \\
\hline 色 & & & 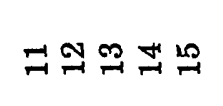 & 48 & ざ \\
\hline
\end{tabular}




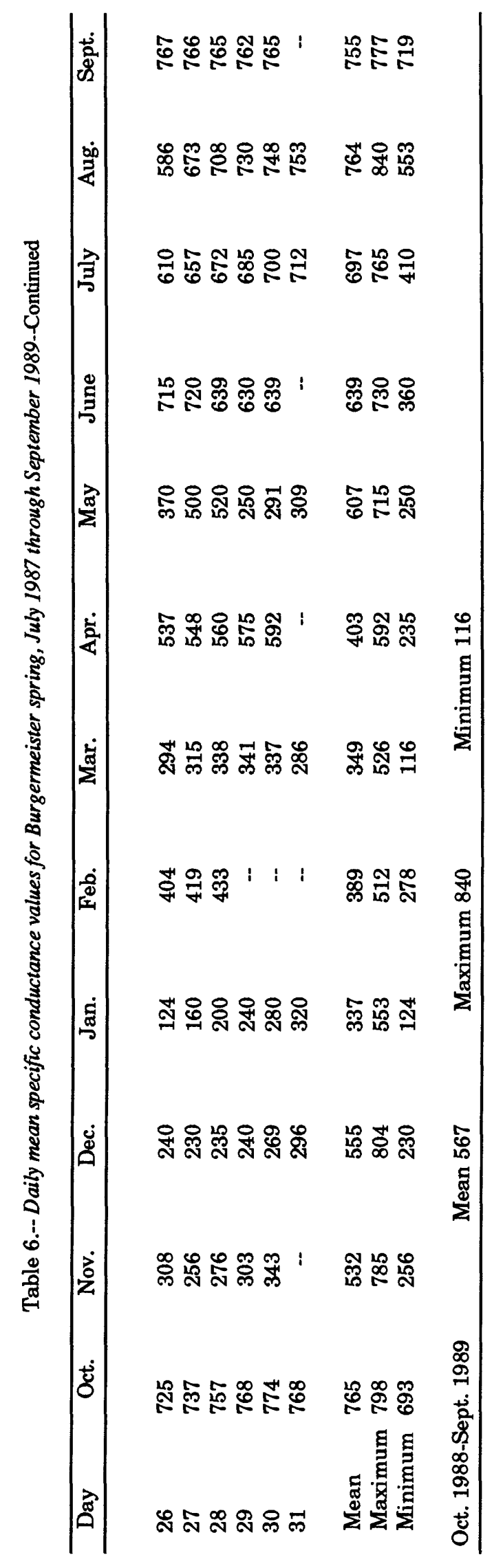




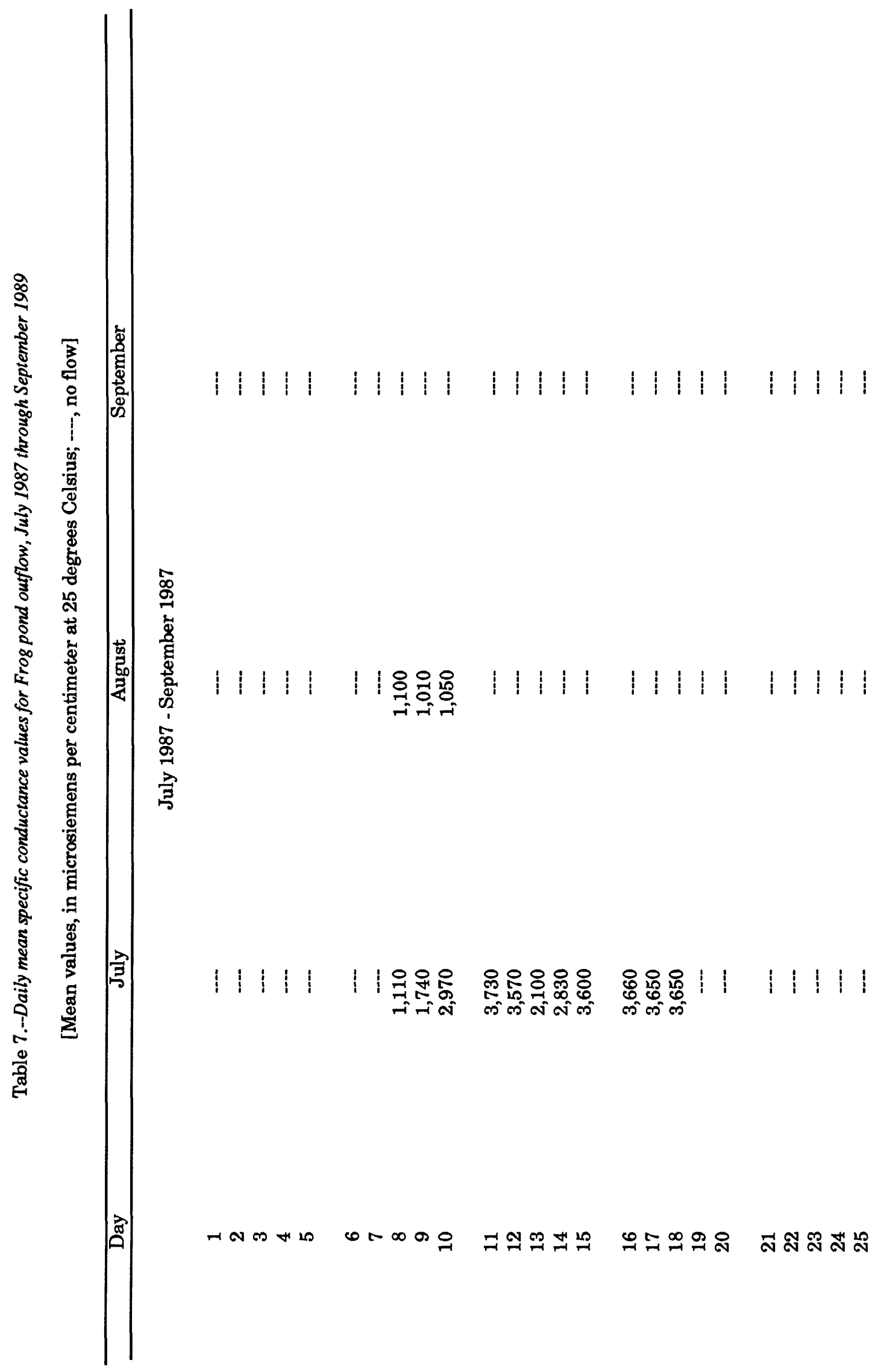




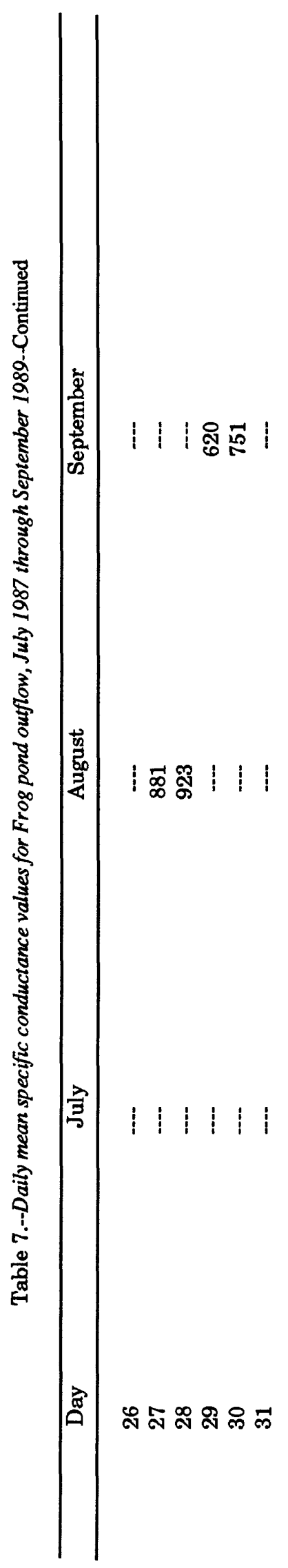




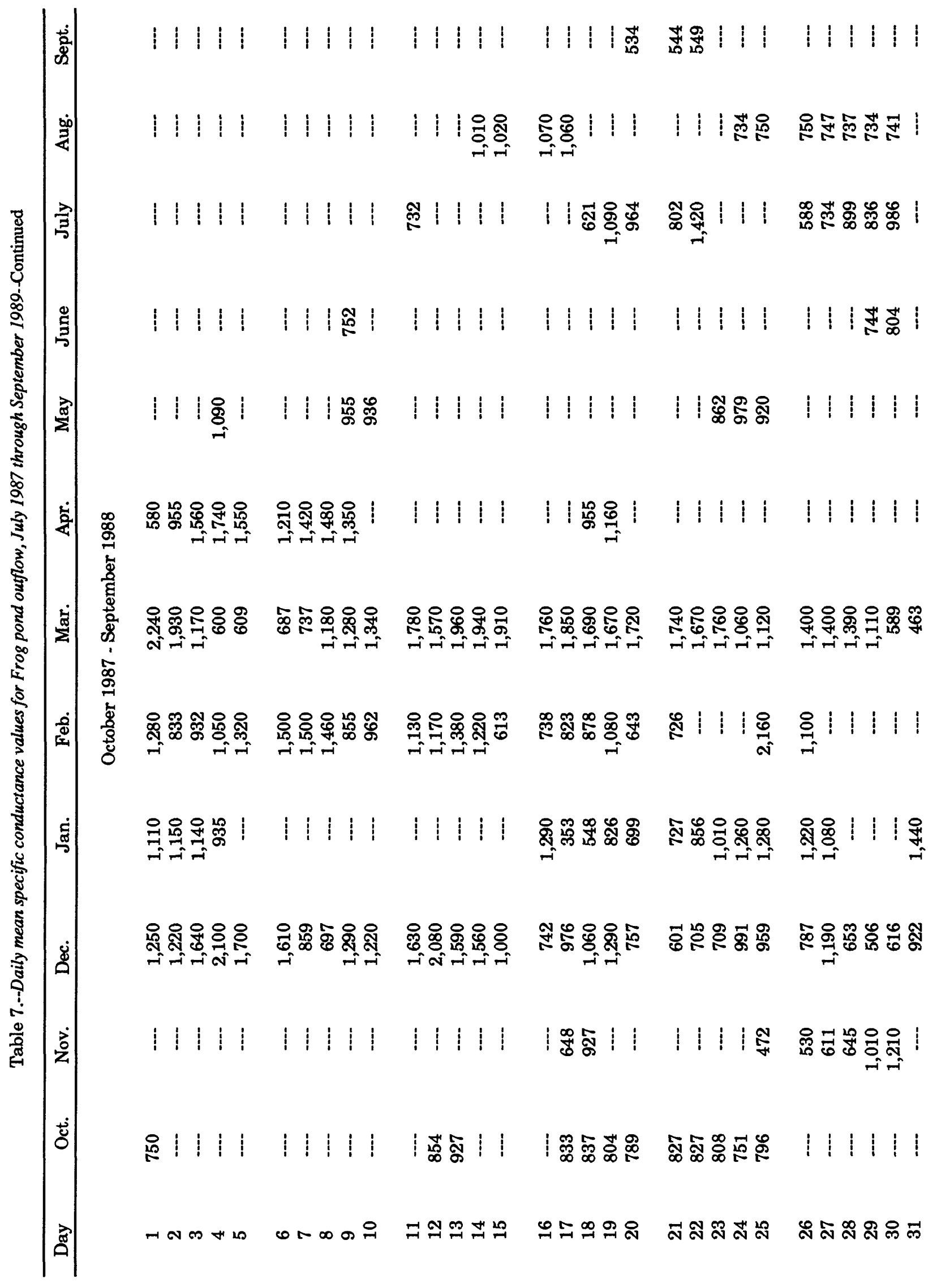




\begin{tabular}{|c|c|c|c|c|c|c|}
\hline 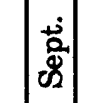 & 象 & 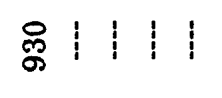 & | & 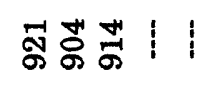 & 11111 & $1: 11111$ \\
\hline 家 & 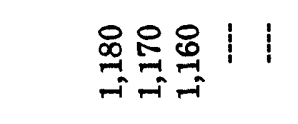 & 11111 & $1: 1: 1$ & 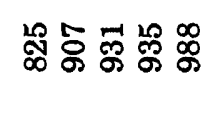 & 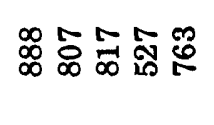 & క్ \\
\hline 全 & 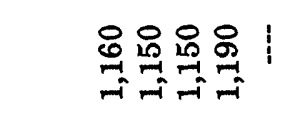 & 11111 & 11111 & $1: 11 \underset{\infty}{ }$ & 范 & 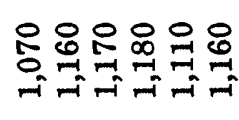 \\
\hline : & 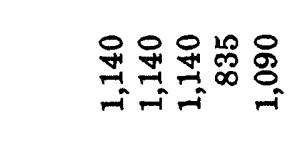 & 路是|| & 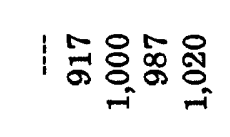 & 육 & 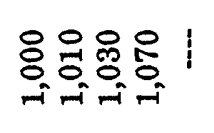 & | 年是是 \\
\hline 这 & 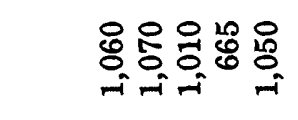 & 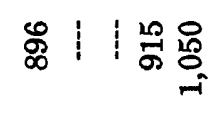 & 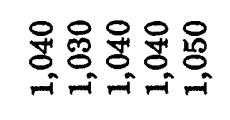 & 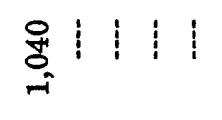 & | & 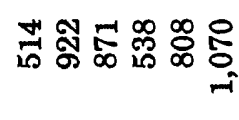 \\
\hline 安 & 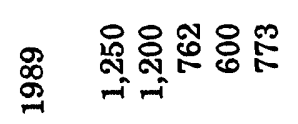 & 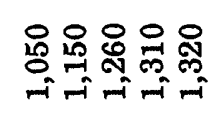 & 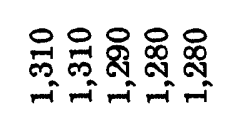 & 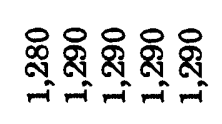 & 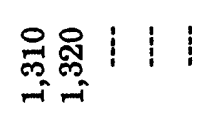 & 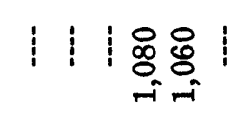 \\
\hline | & 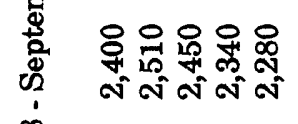 & 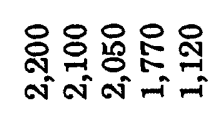 & 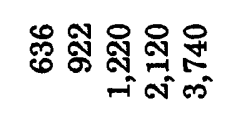 & 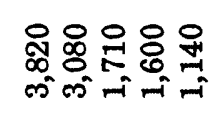 & 항 & 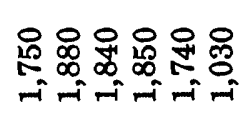 \\
\hline 定 & 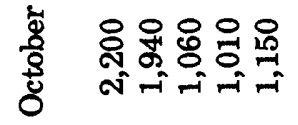 & 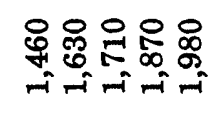 & 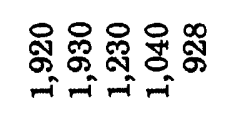 & 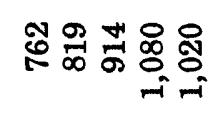 & 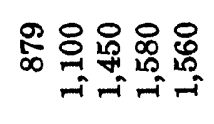 & 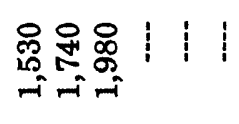 \\
\hline 宛 & 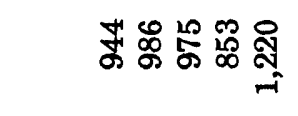 & ఇ్రీ & 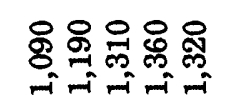 & 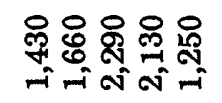 & 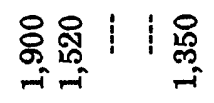 & 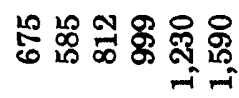 \\
\hline هั่ & 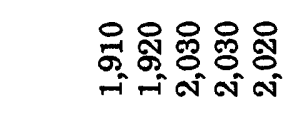 & 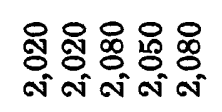 & 1111 & $11: 11$ & | & \&్త్రి: \\
\hline 客 & 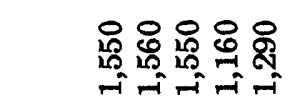 & 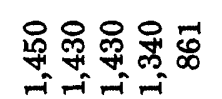 & 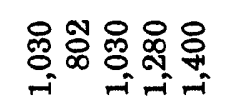 & 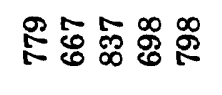 & న్రా : & চ్లో \\
\hline$\dot{0}$ & | & $1: 1111$ & 11111 & 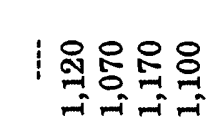 & 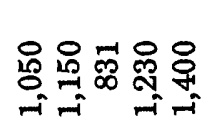 & 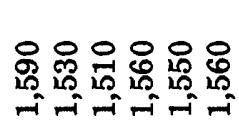 \\
\hline జे & HN & or & $\exists=$ & $\mathscr{0}=$ & ส ส ส & ชั ล \\
\hline
\end{tabular}




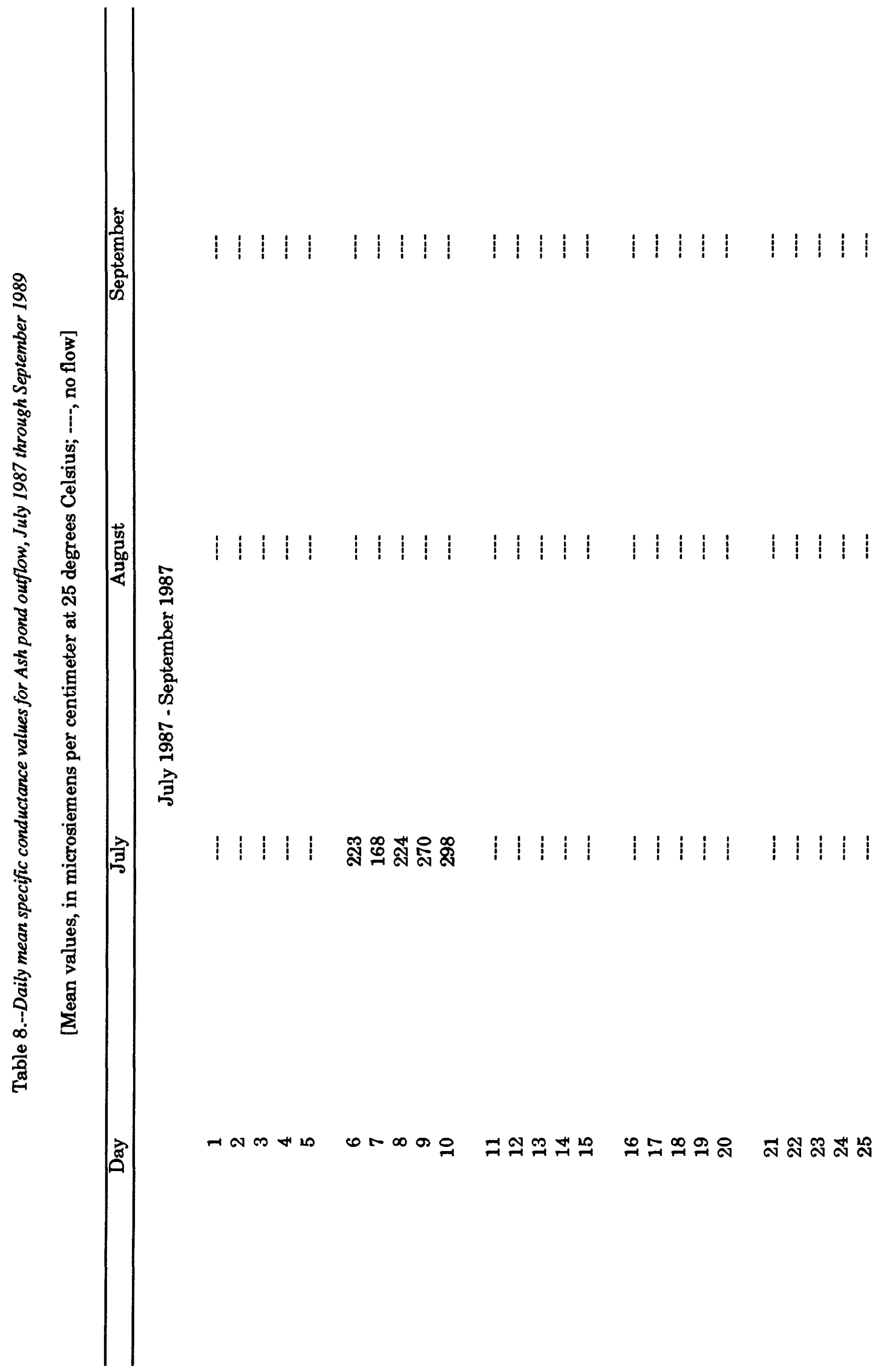




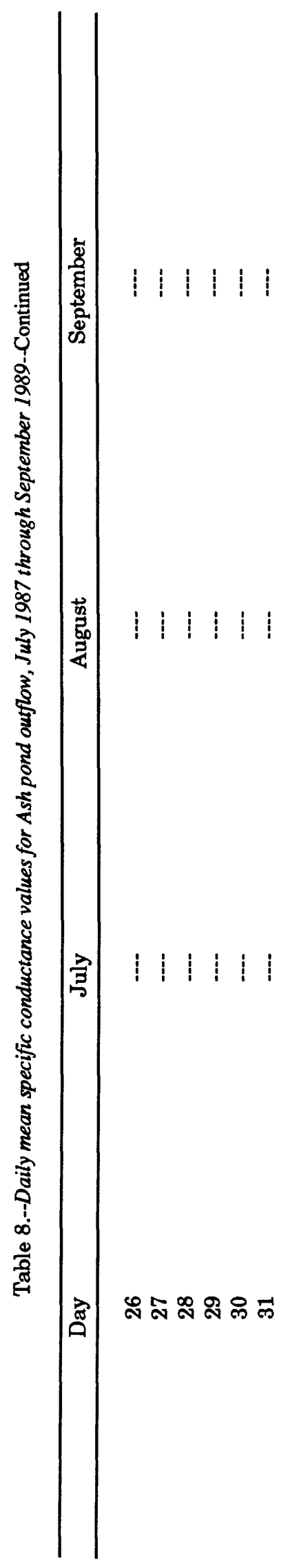




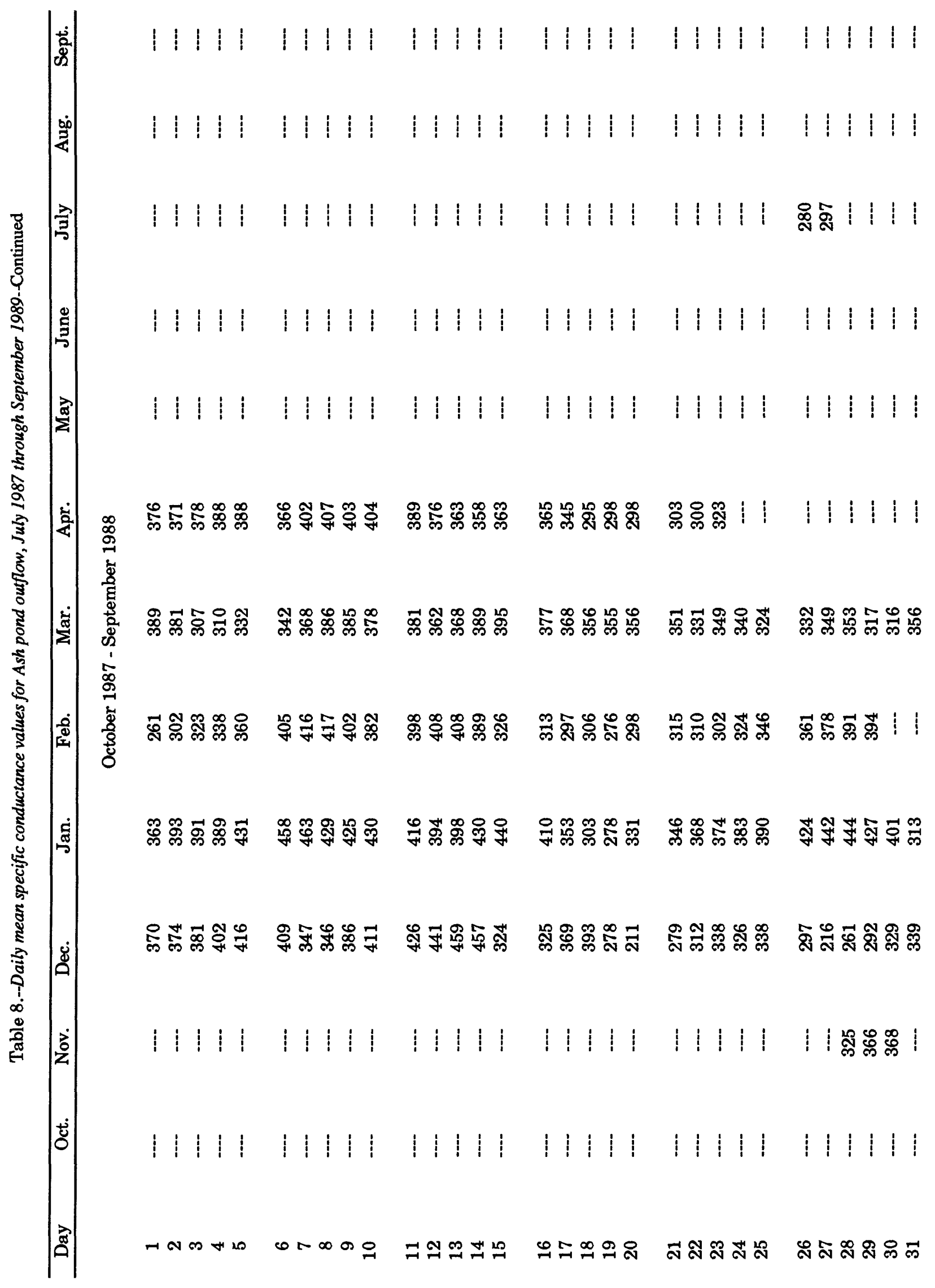




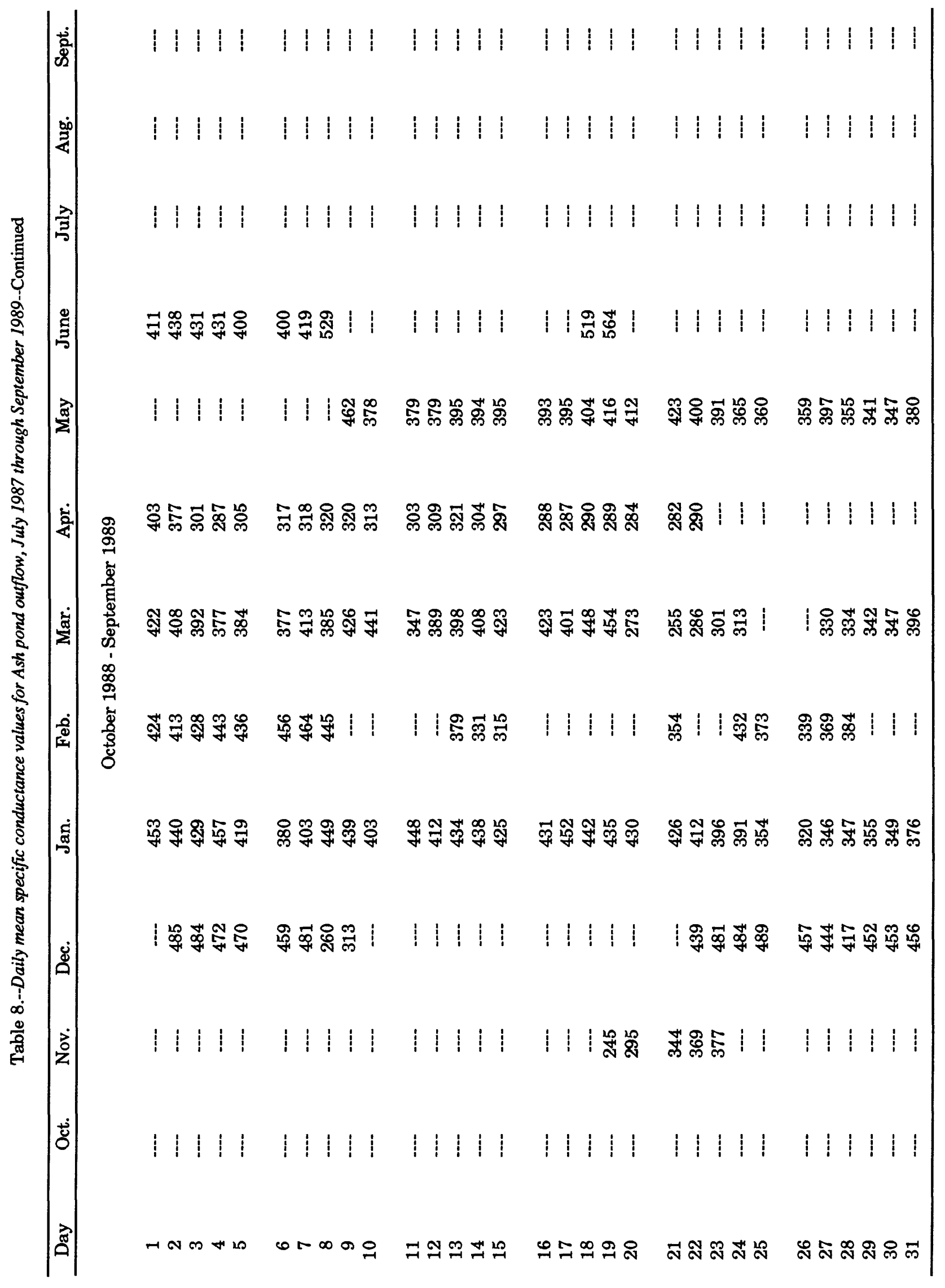




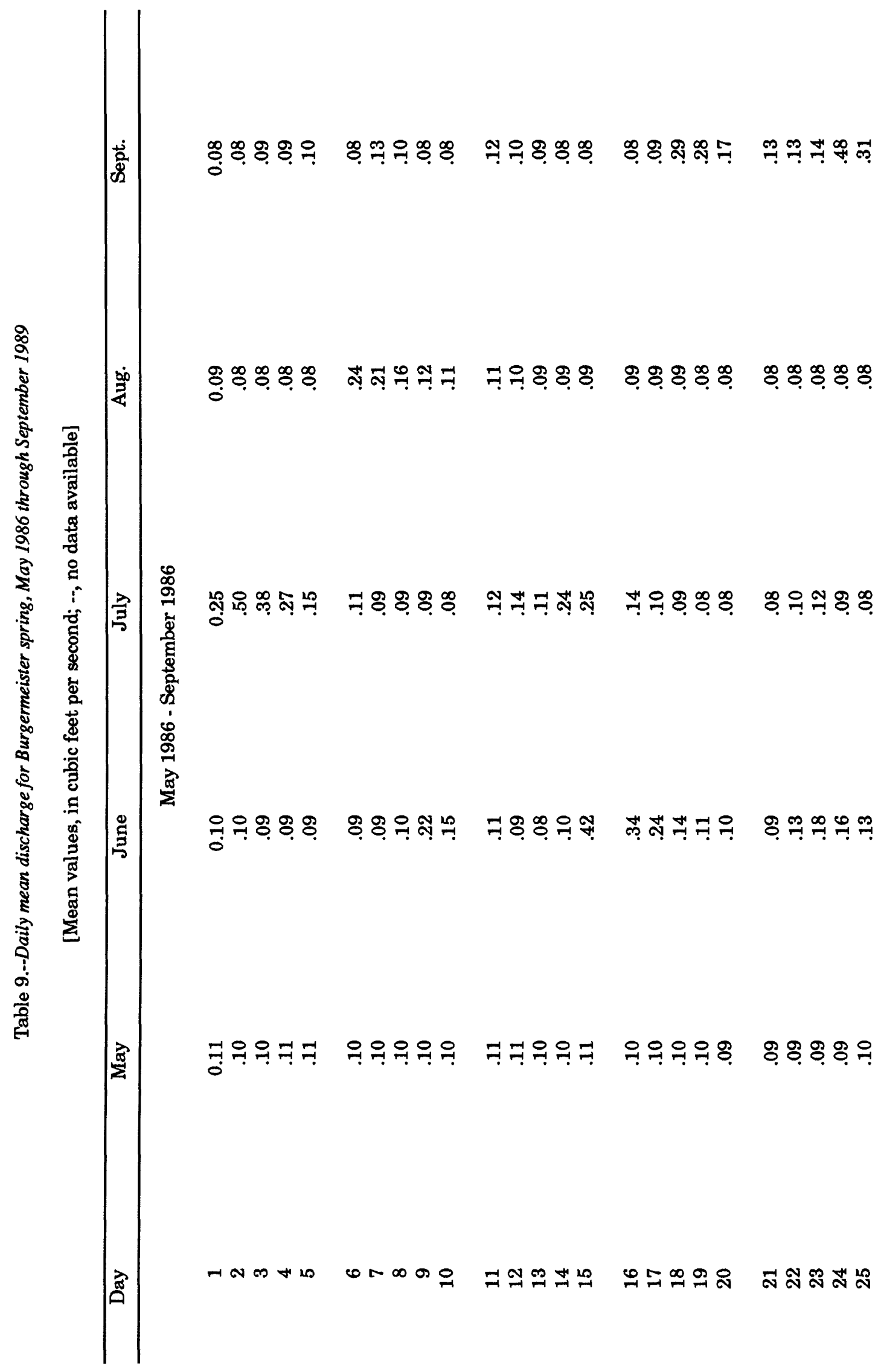




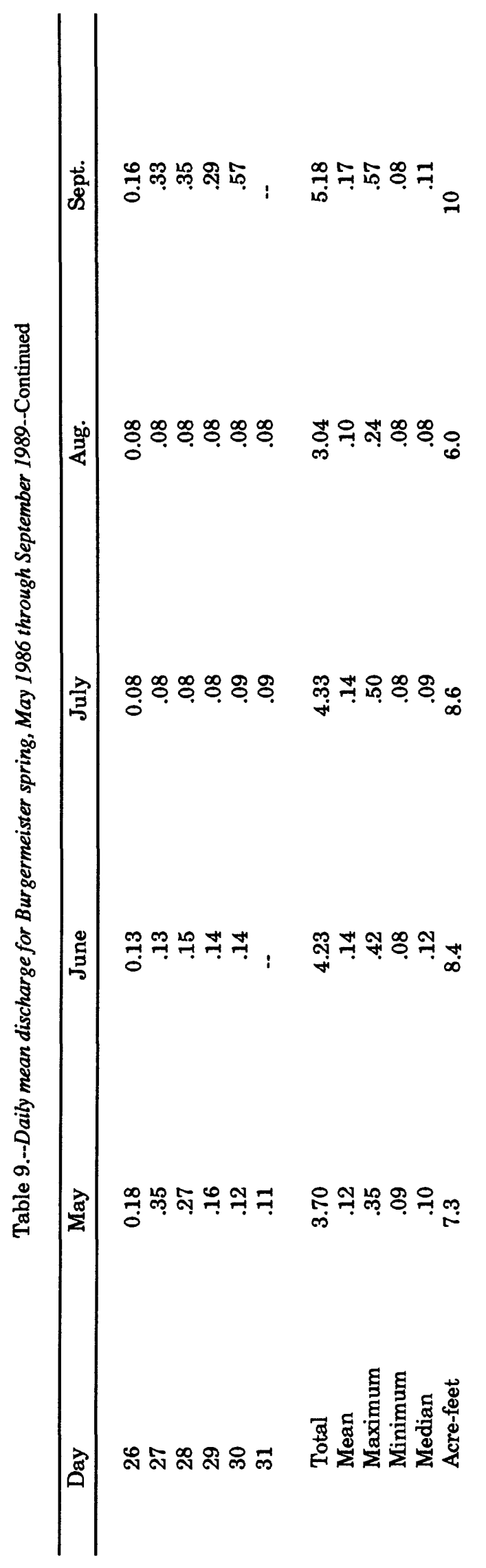




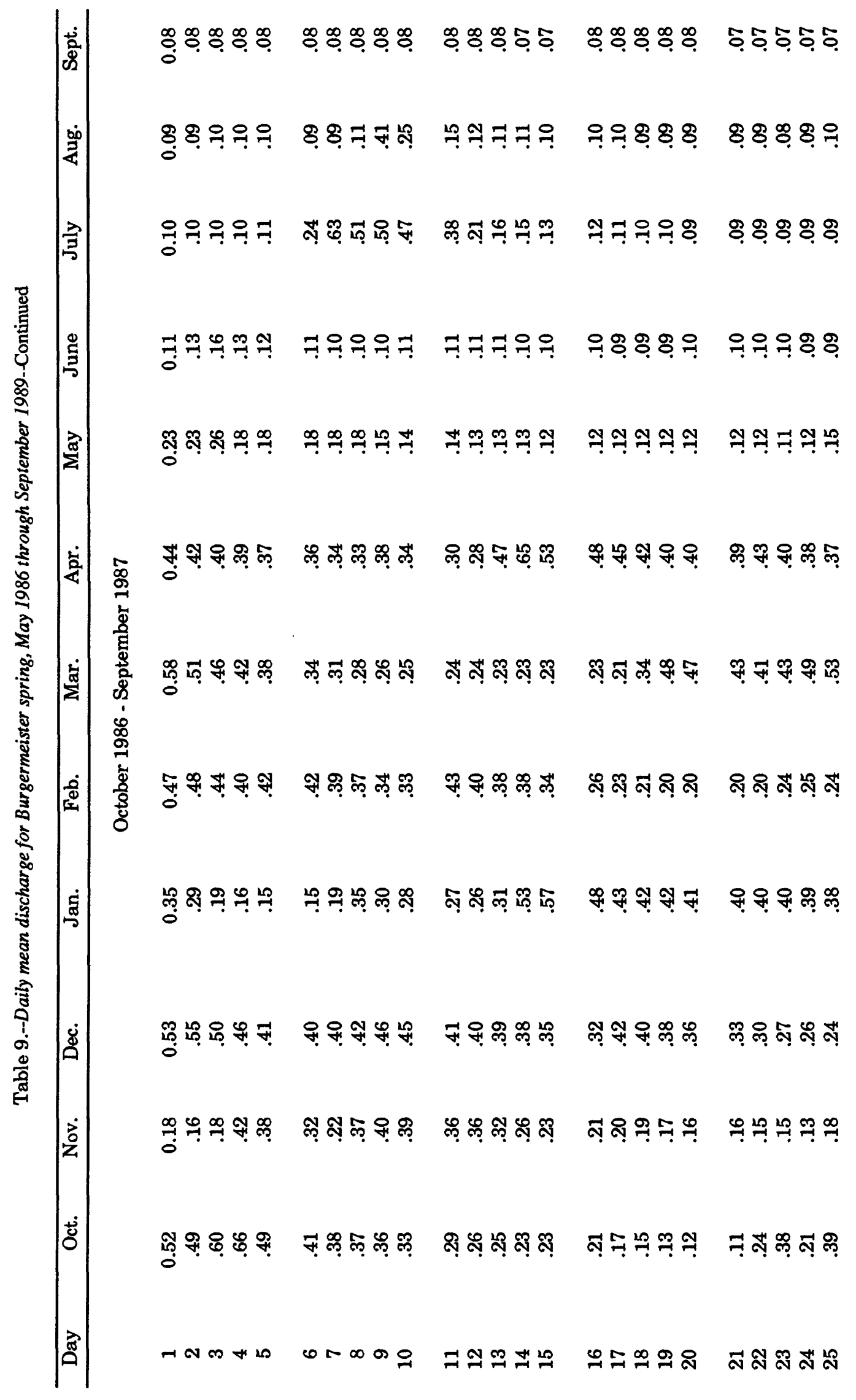




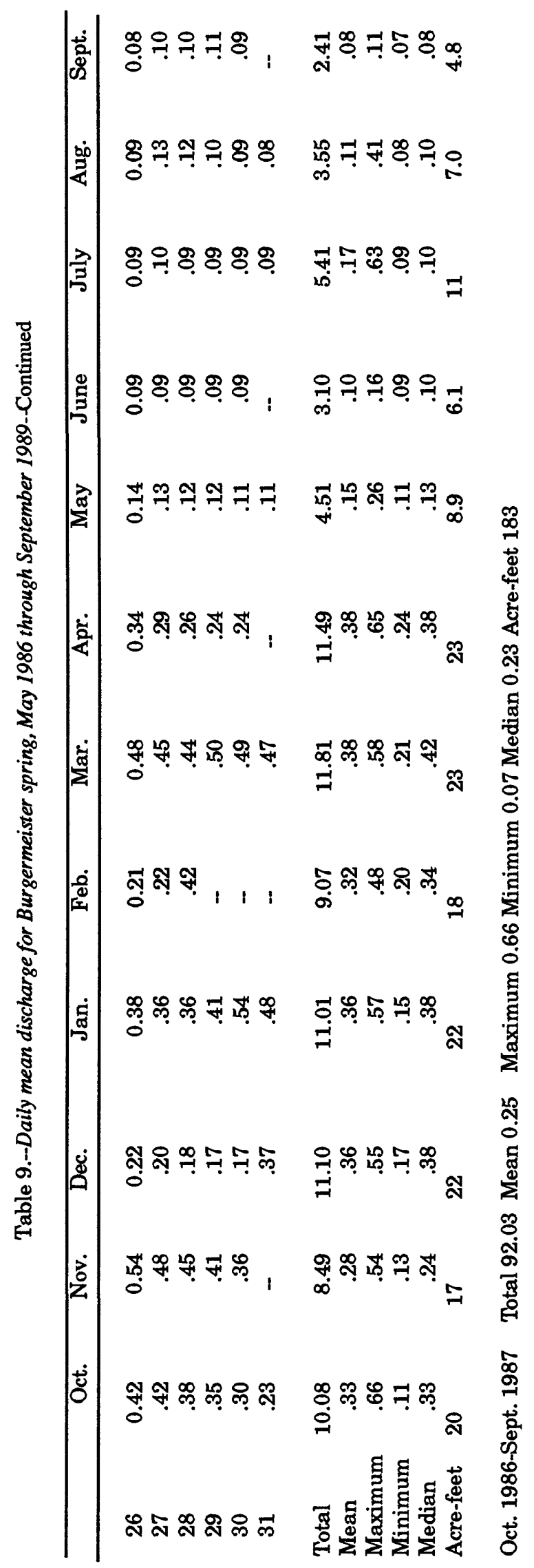




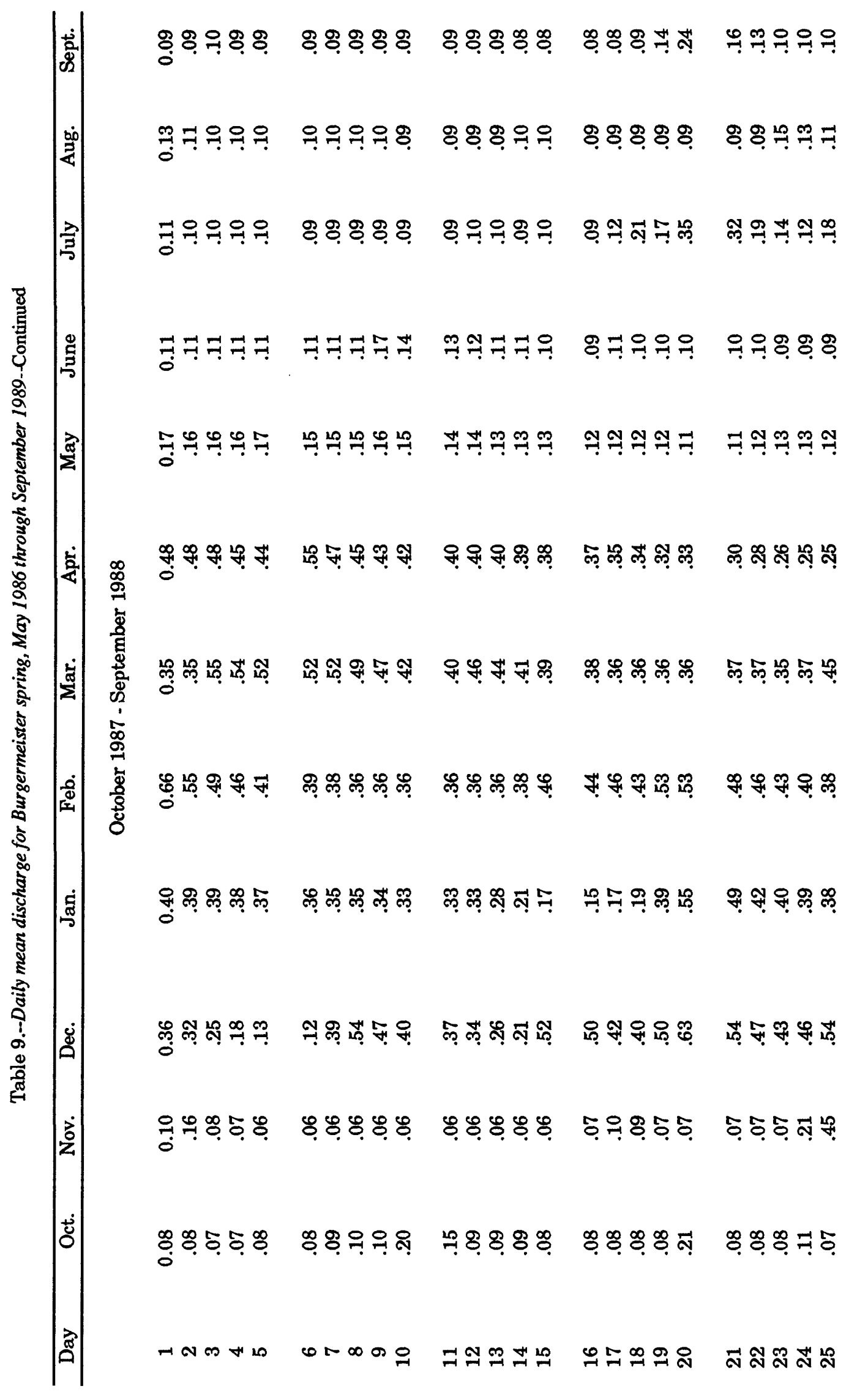




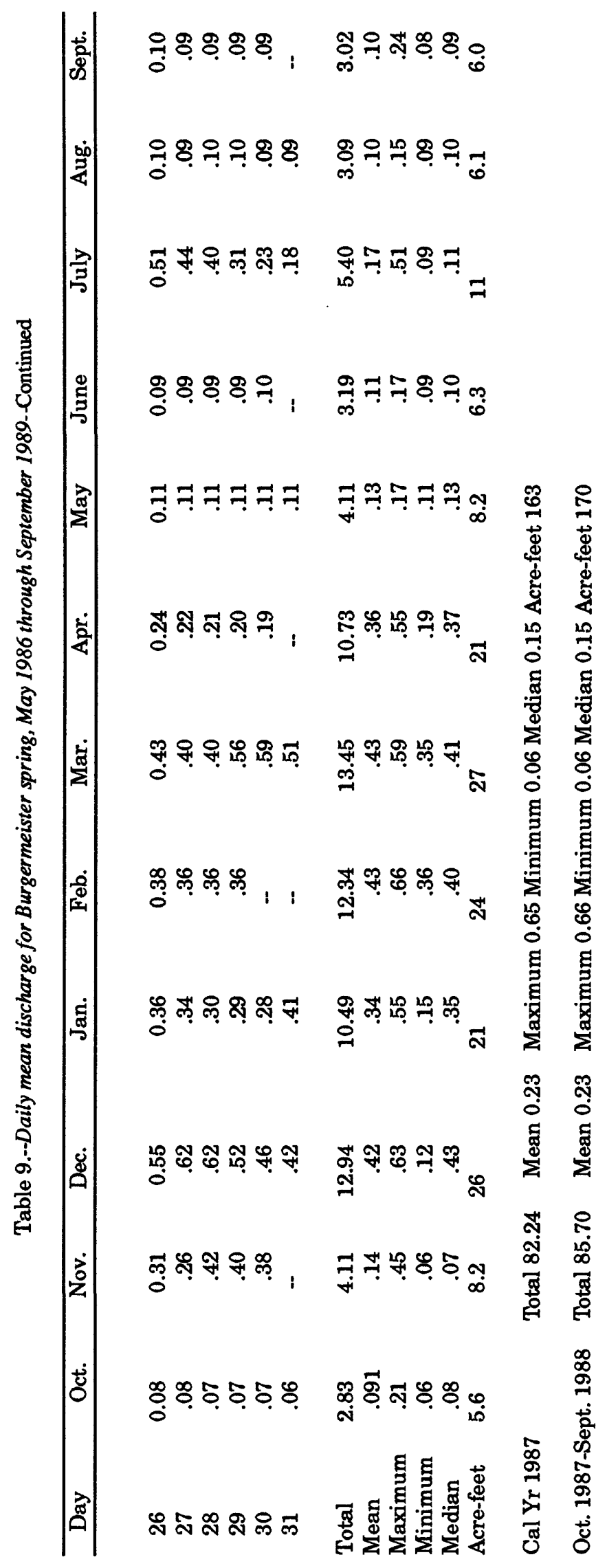




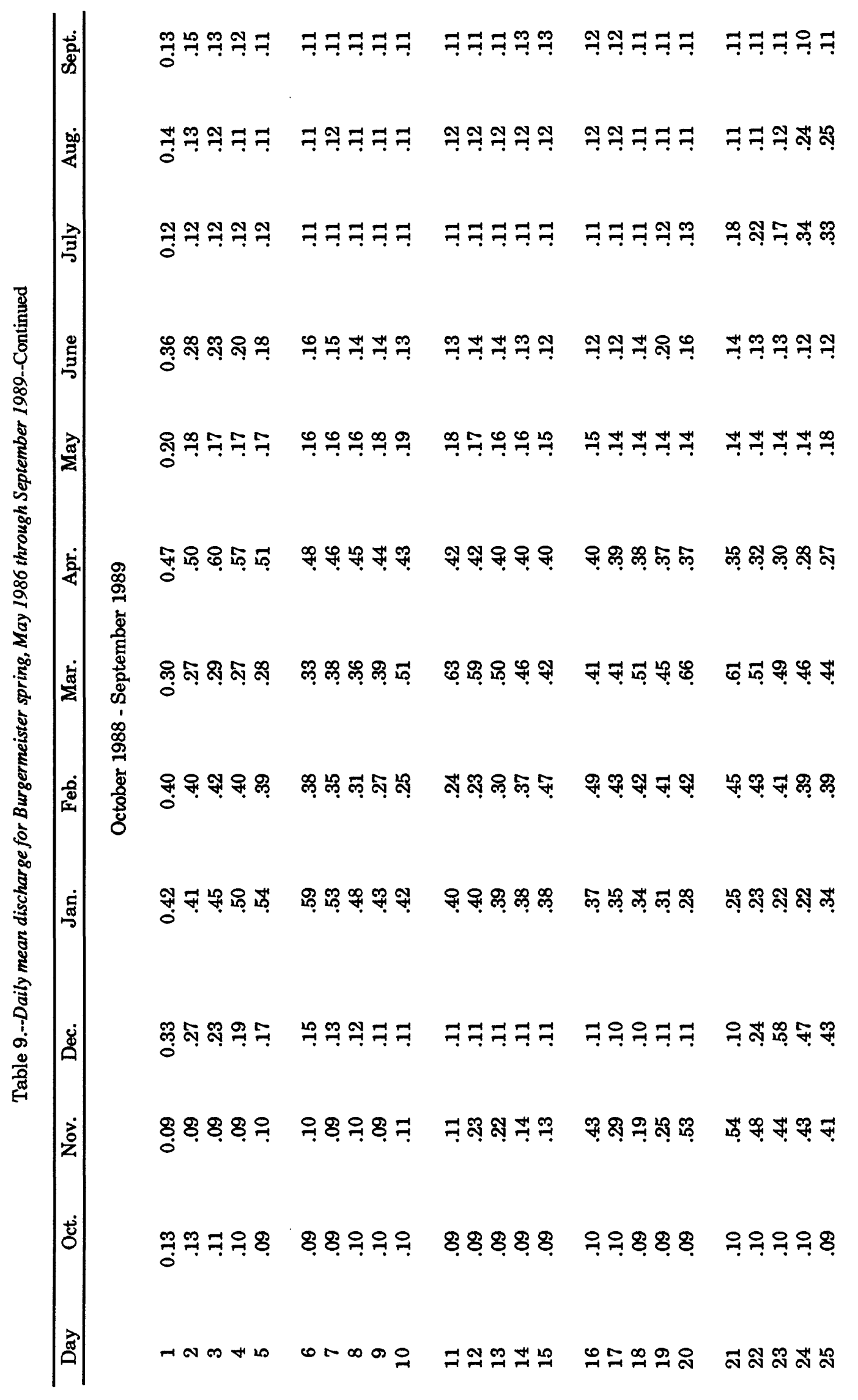




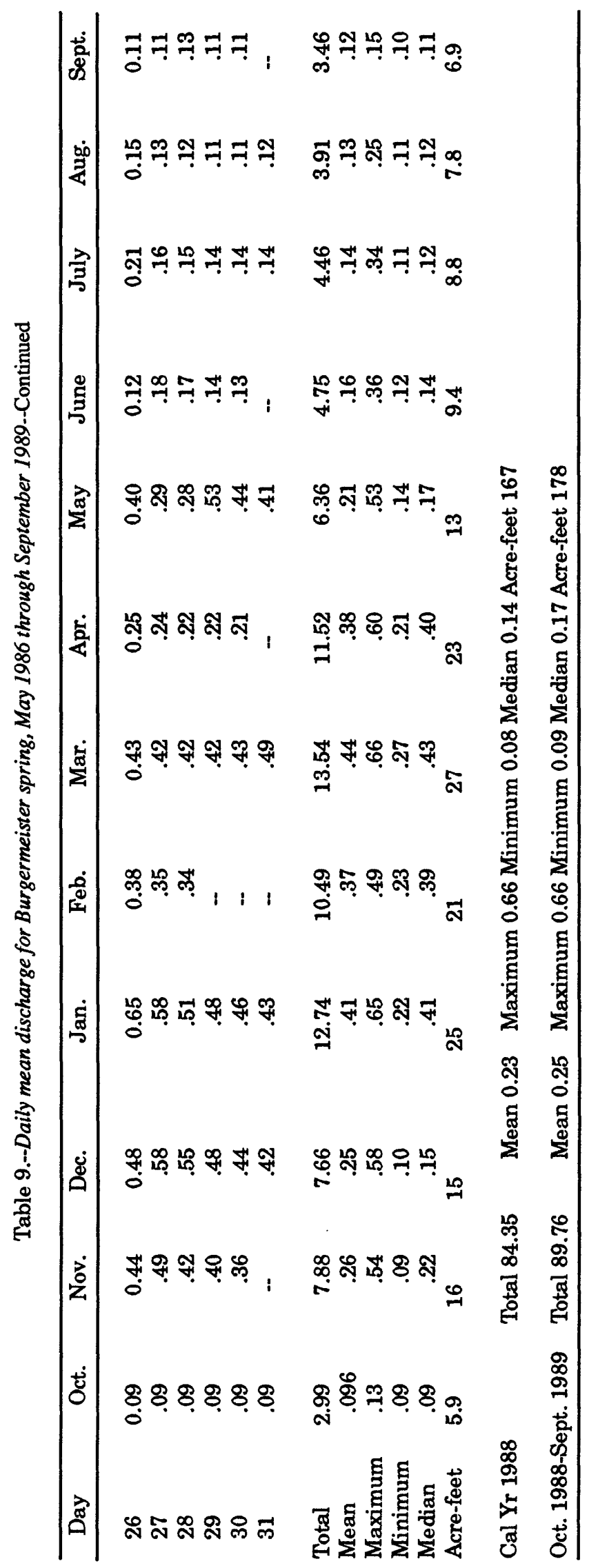




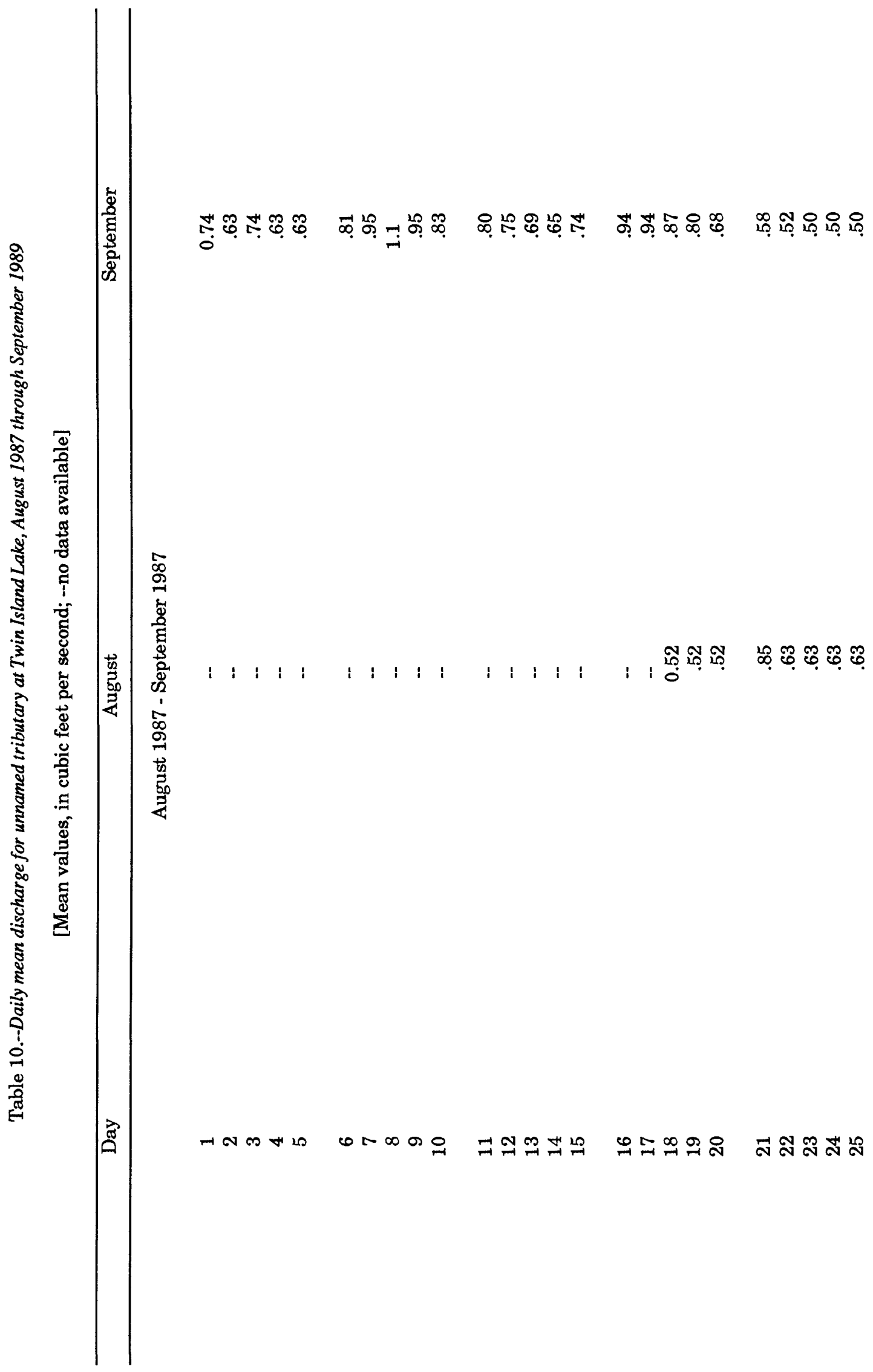




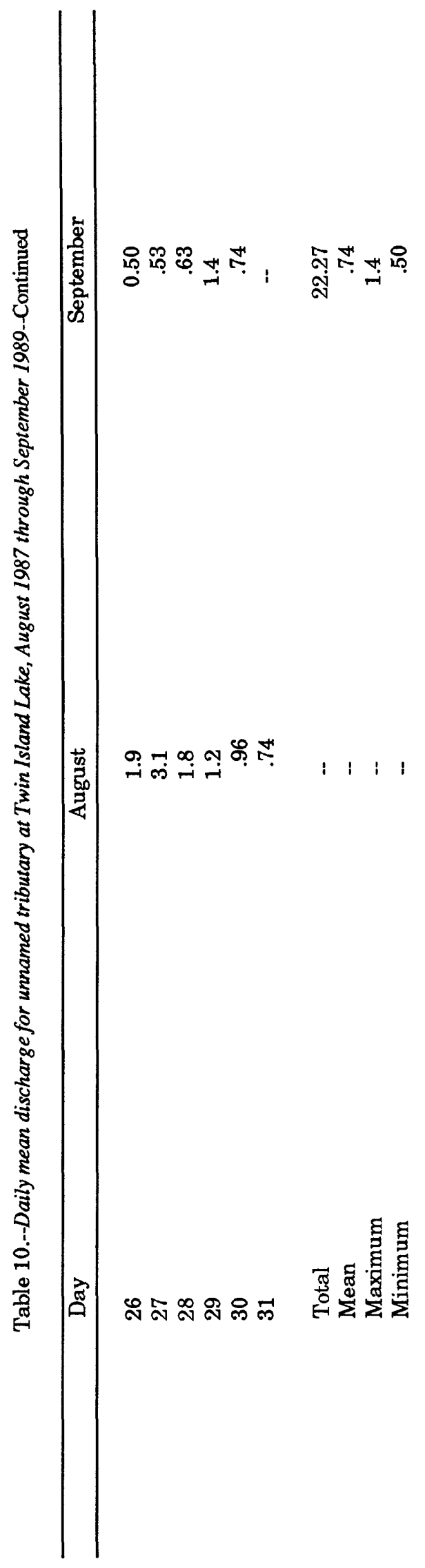




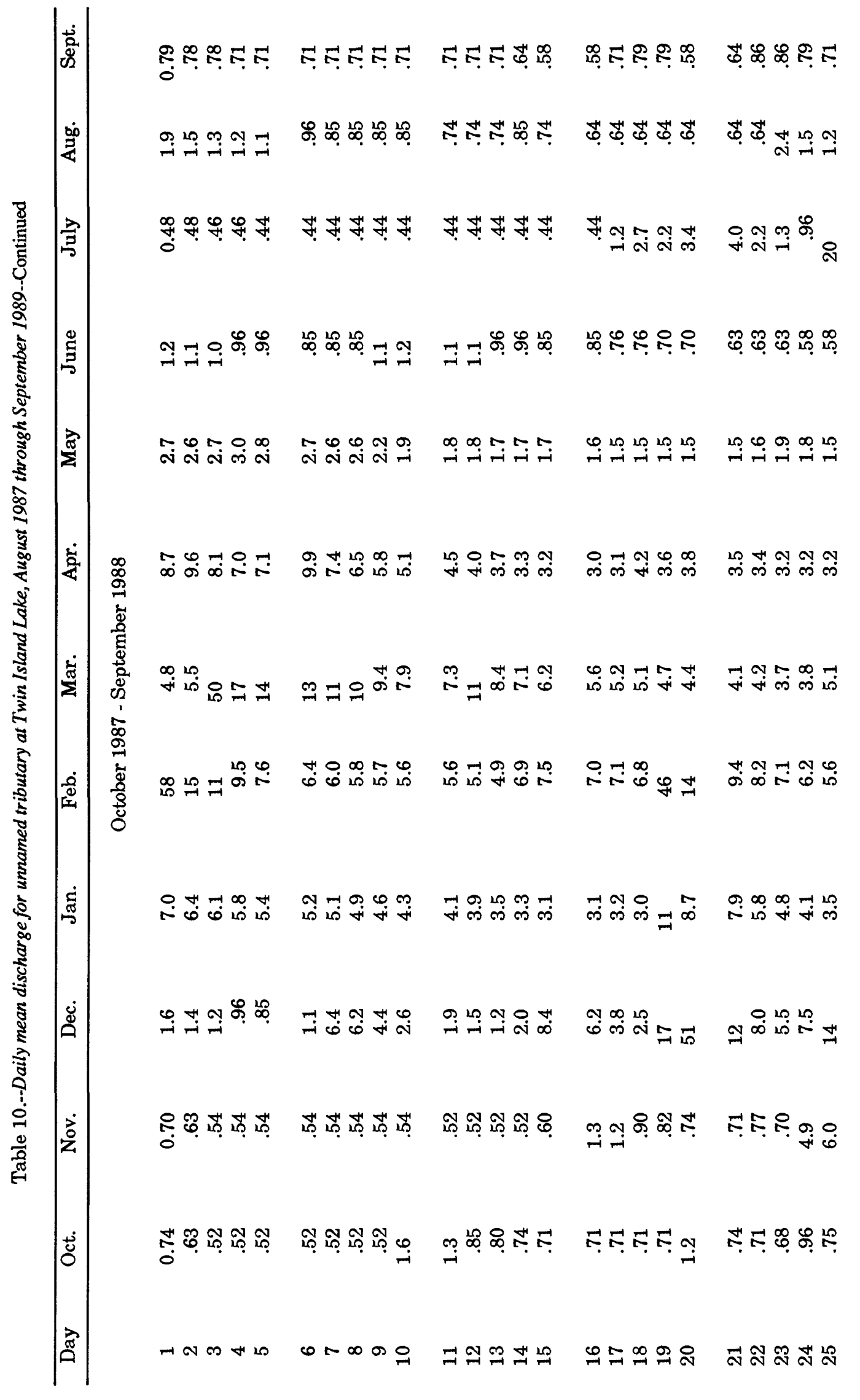




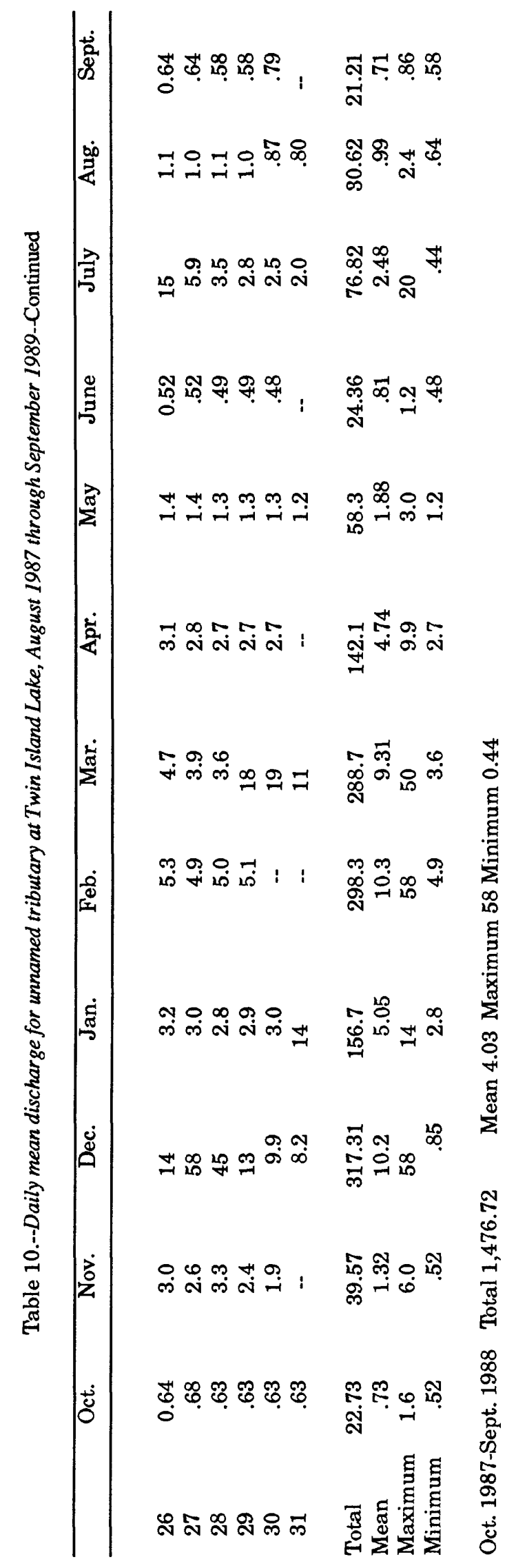




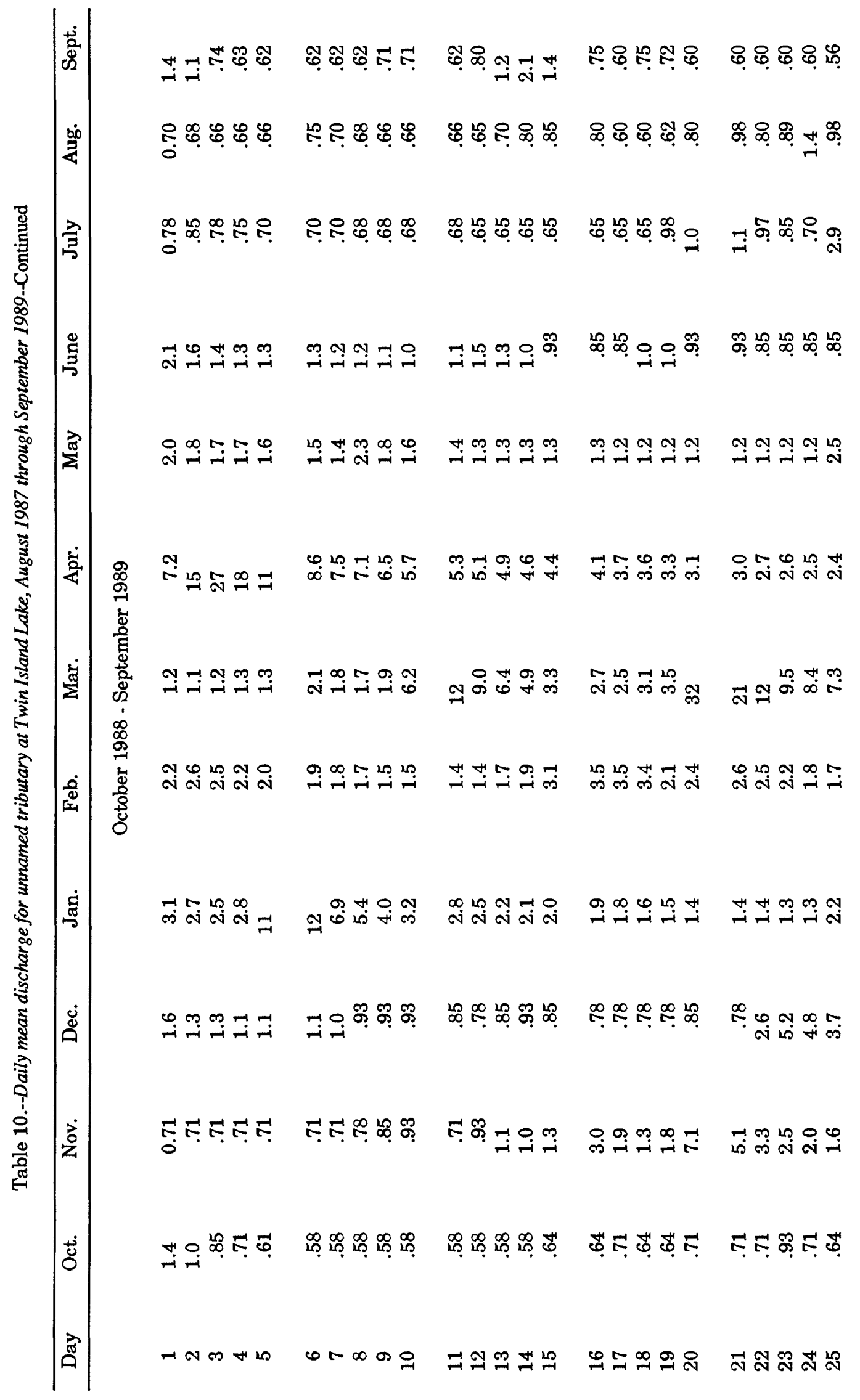




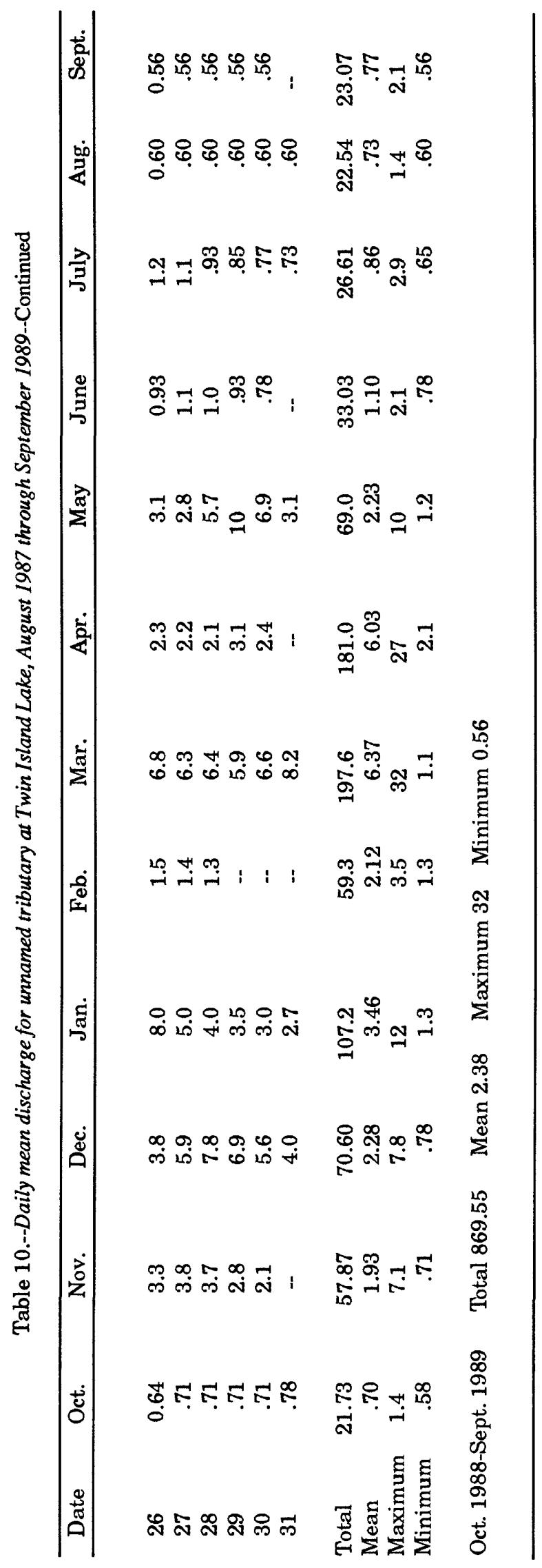




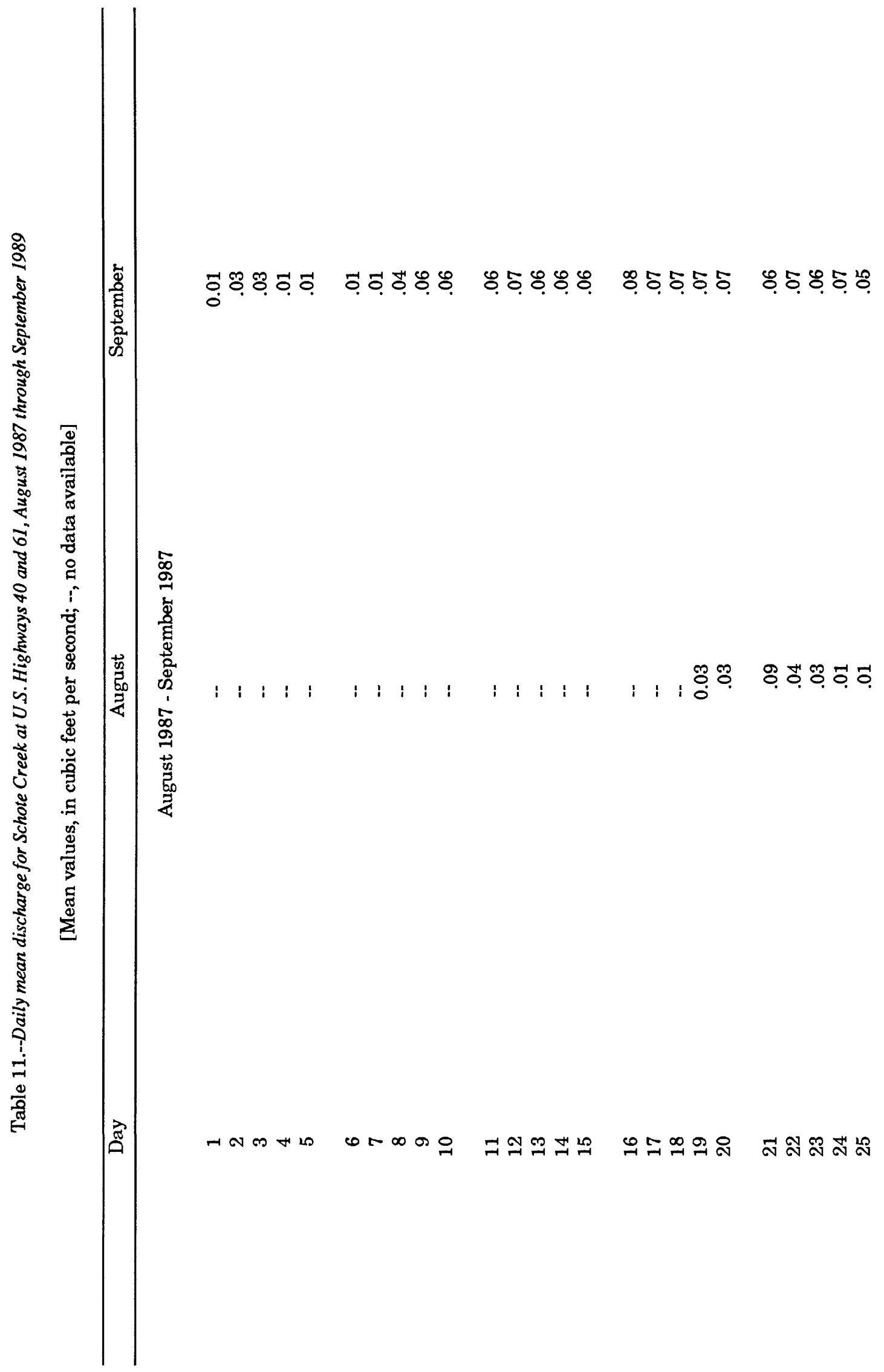




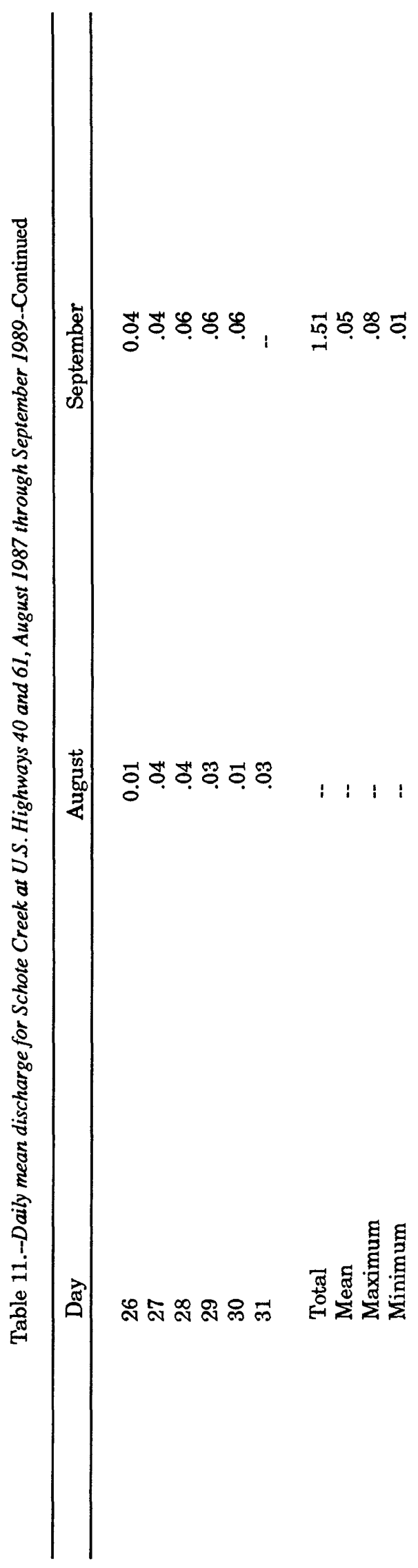

100 


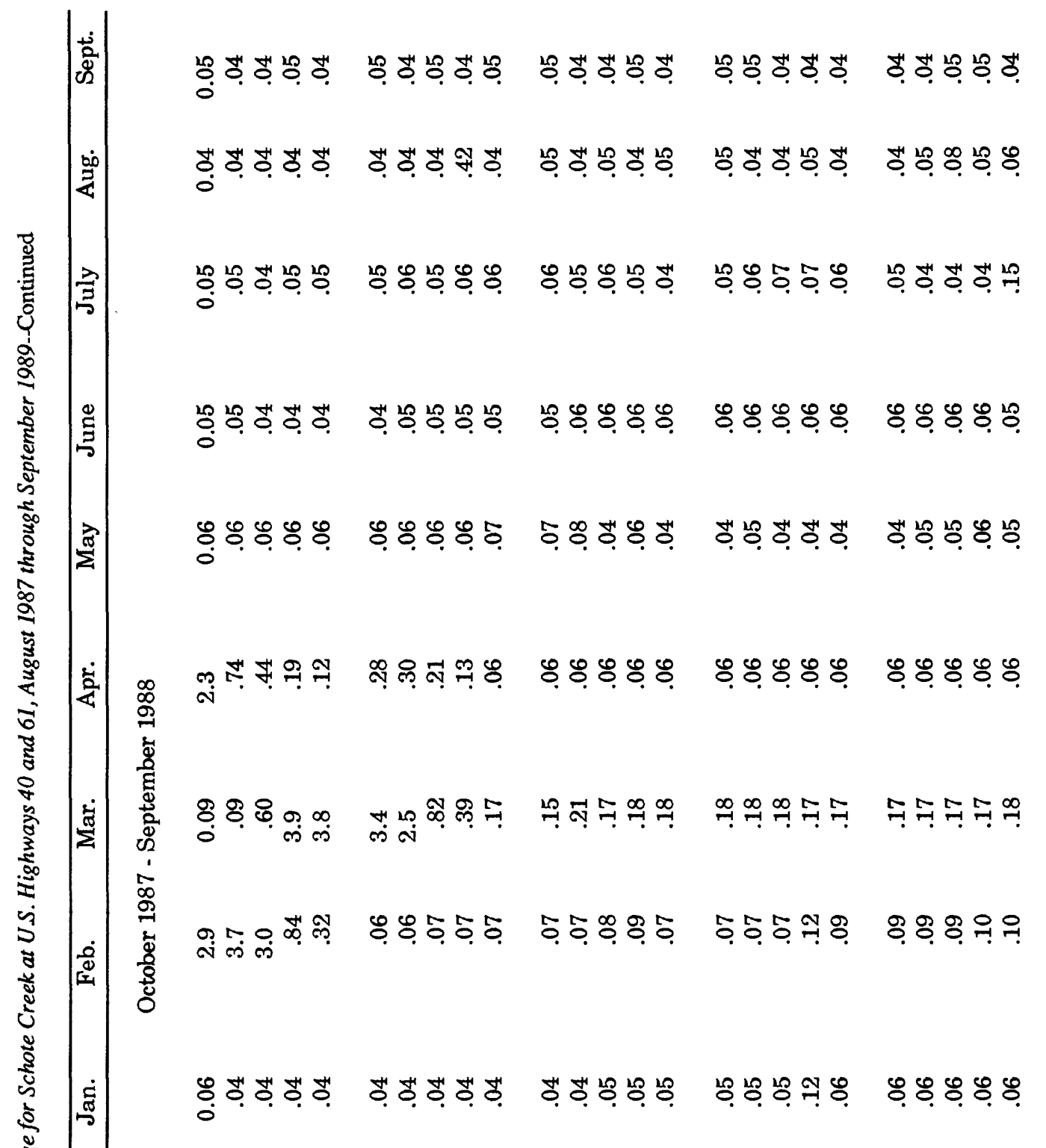

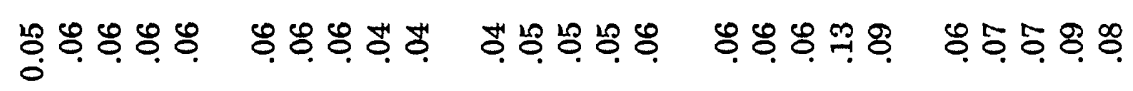

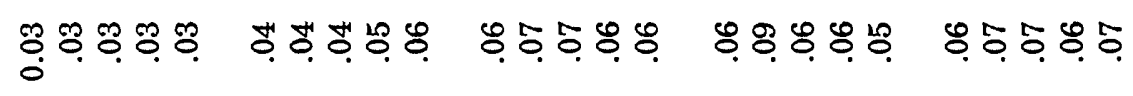

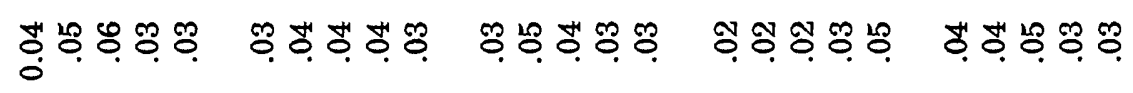
サN 


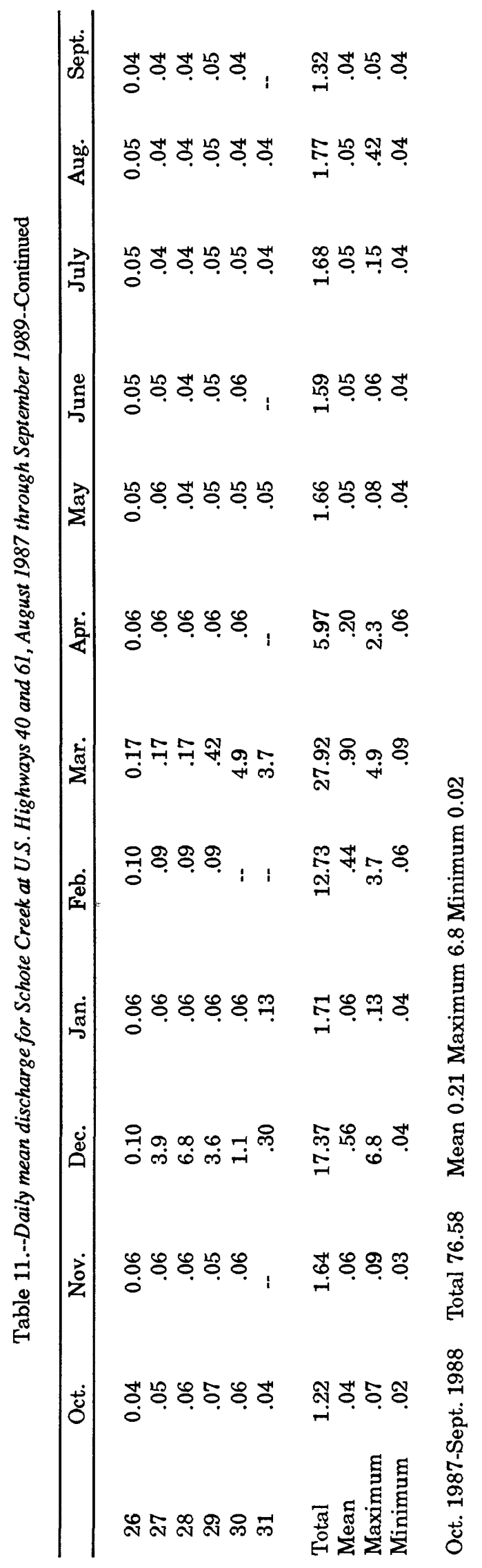




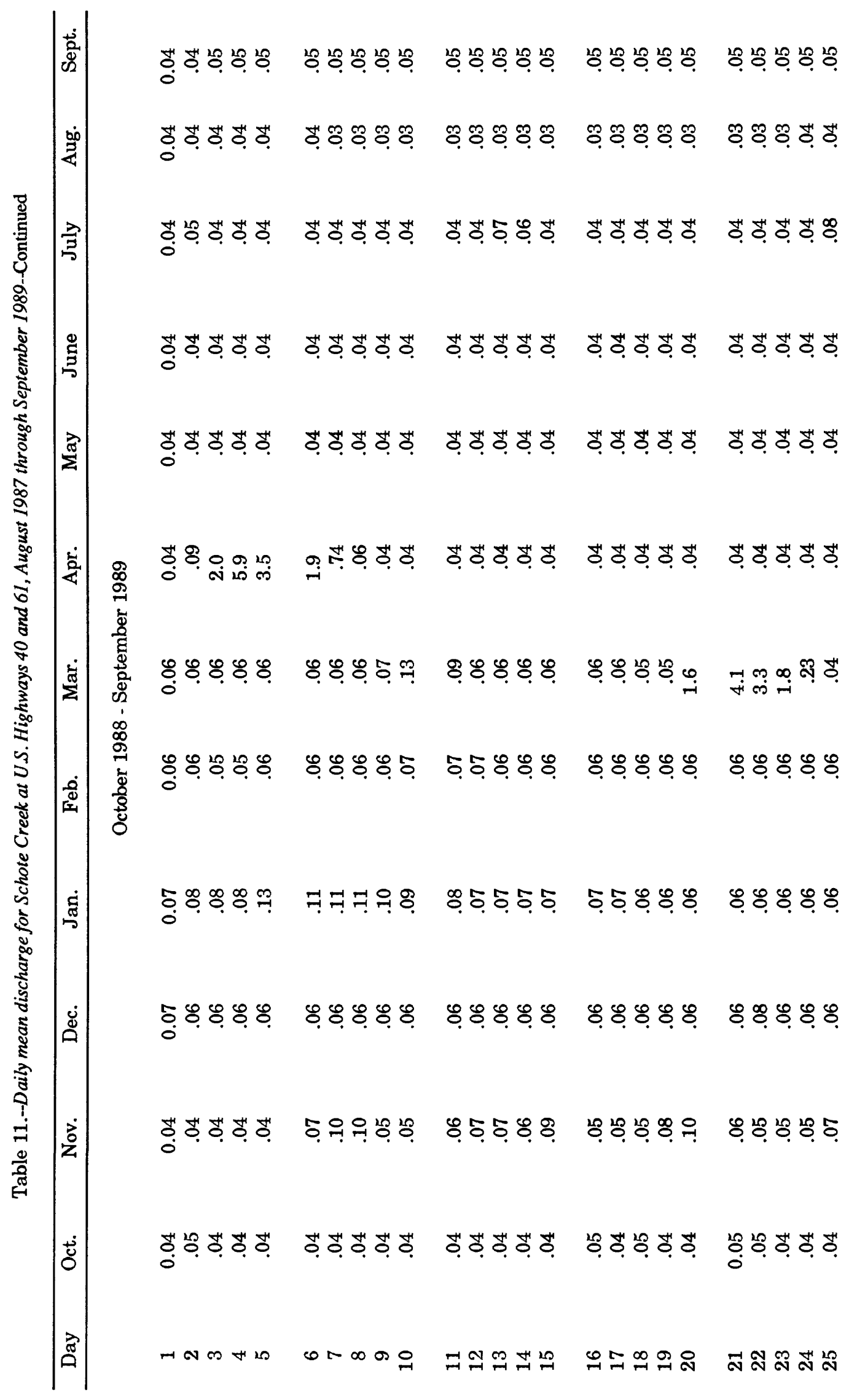




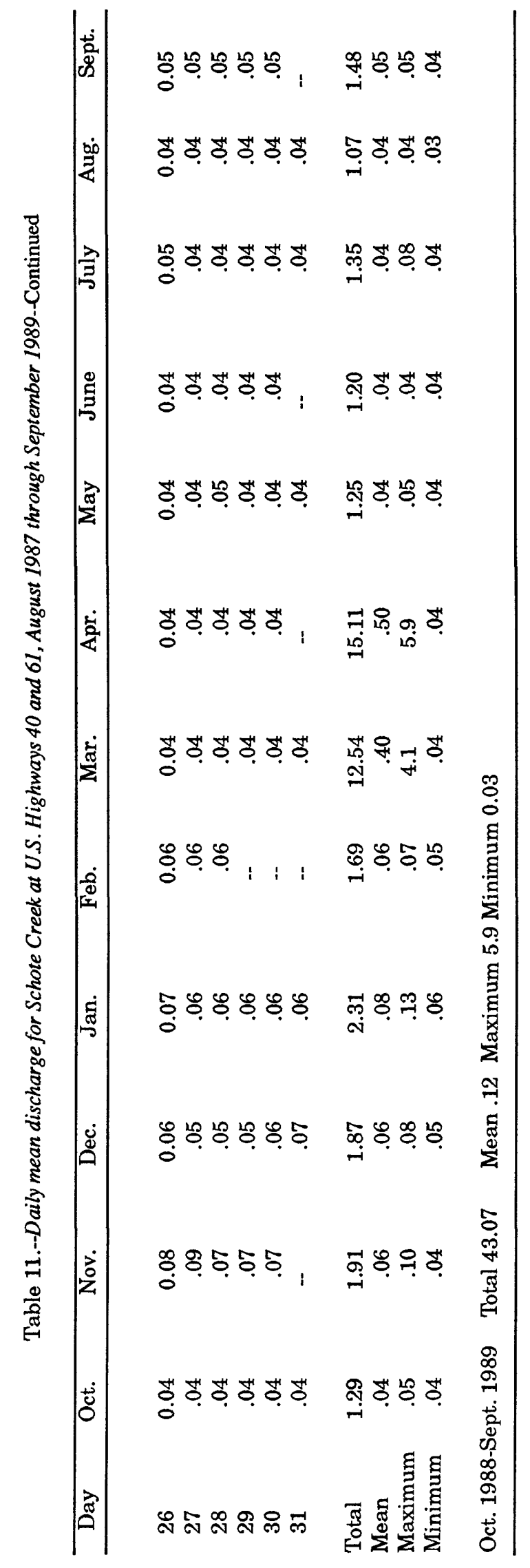




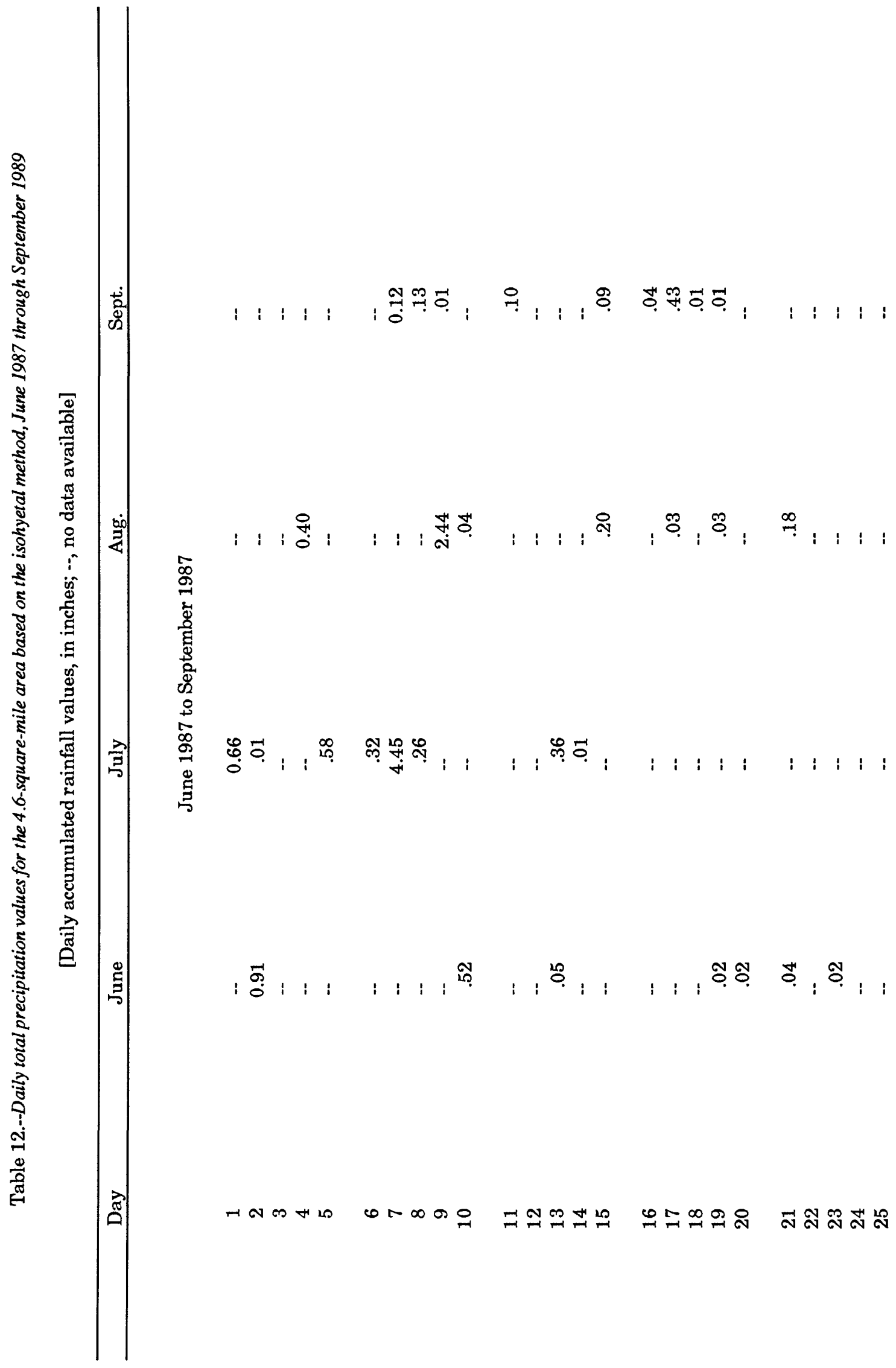




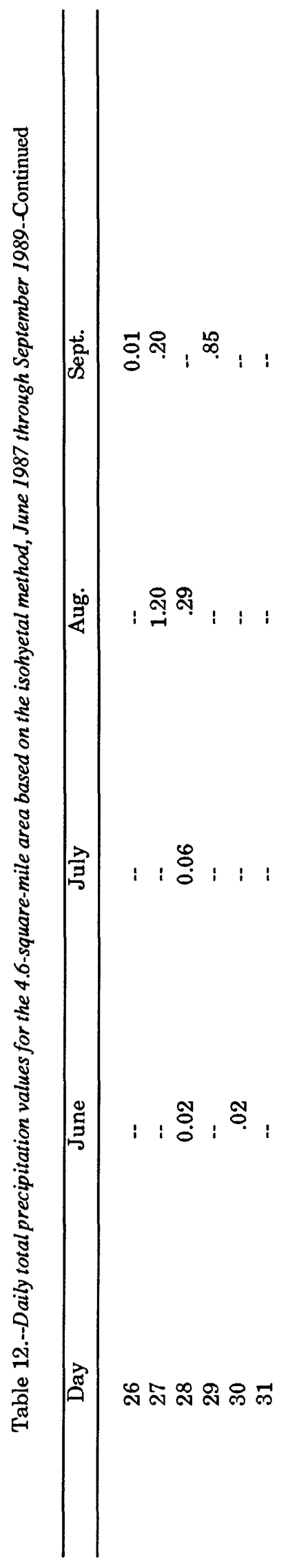




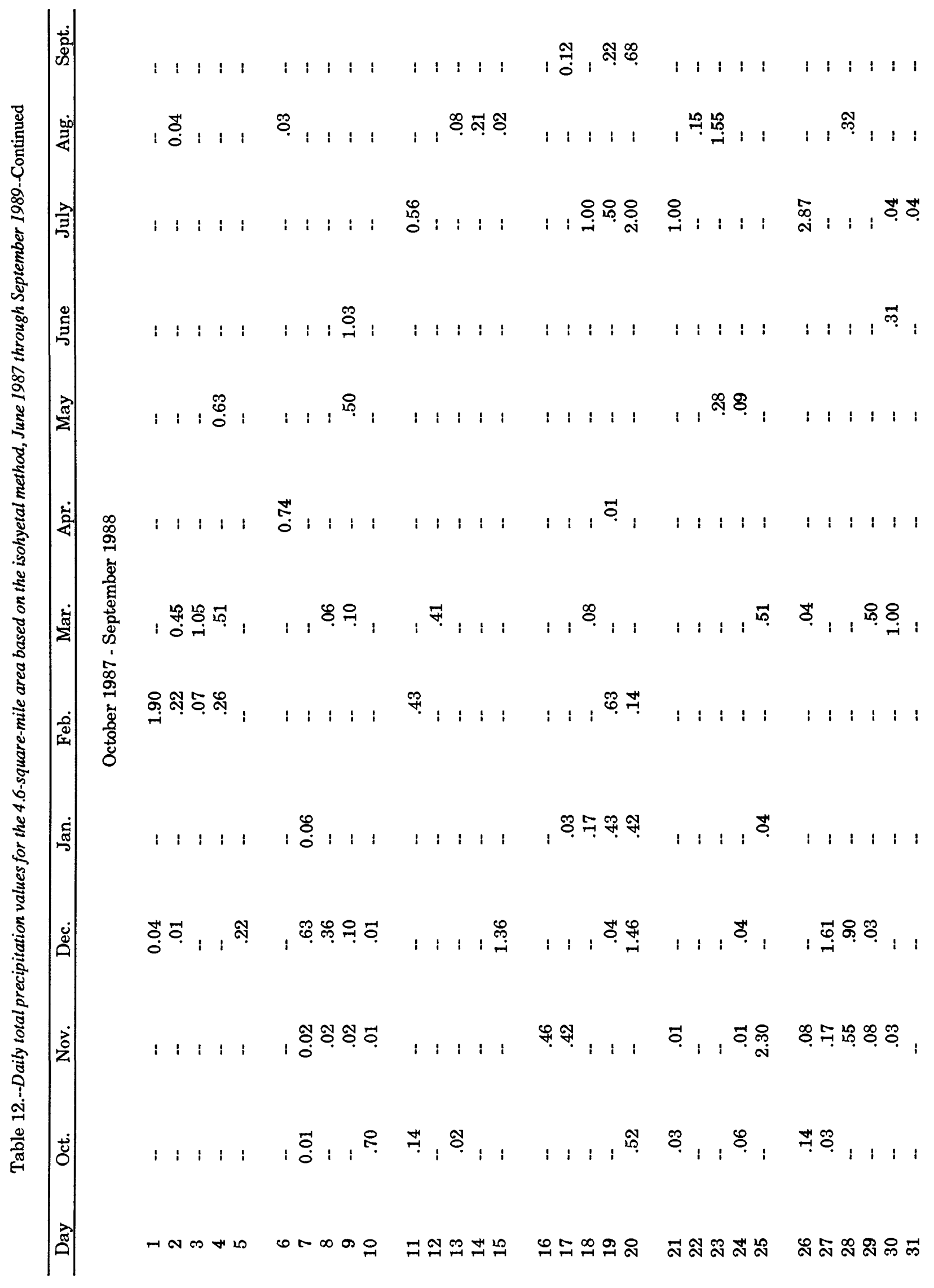




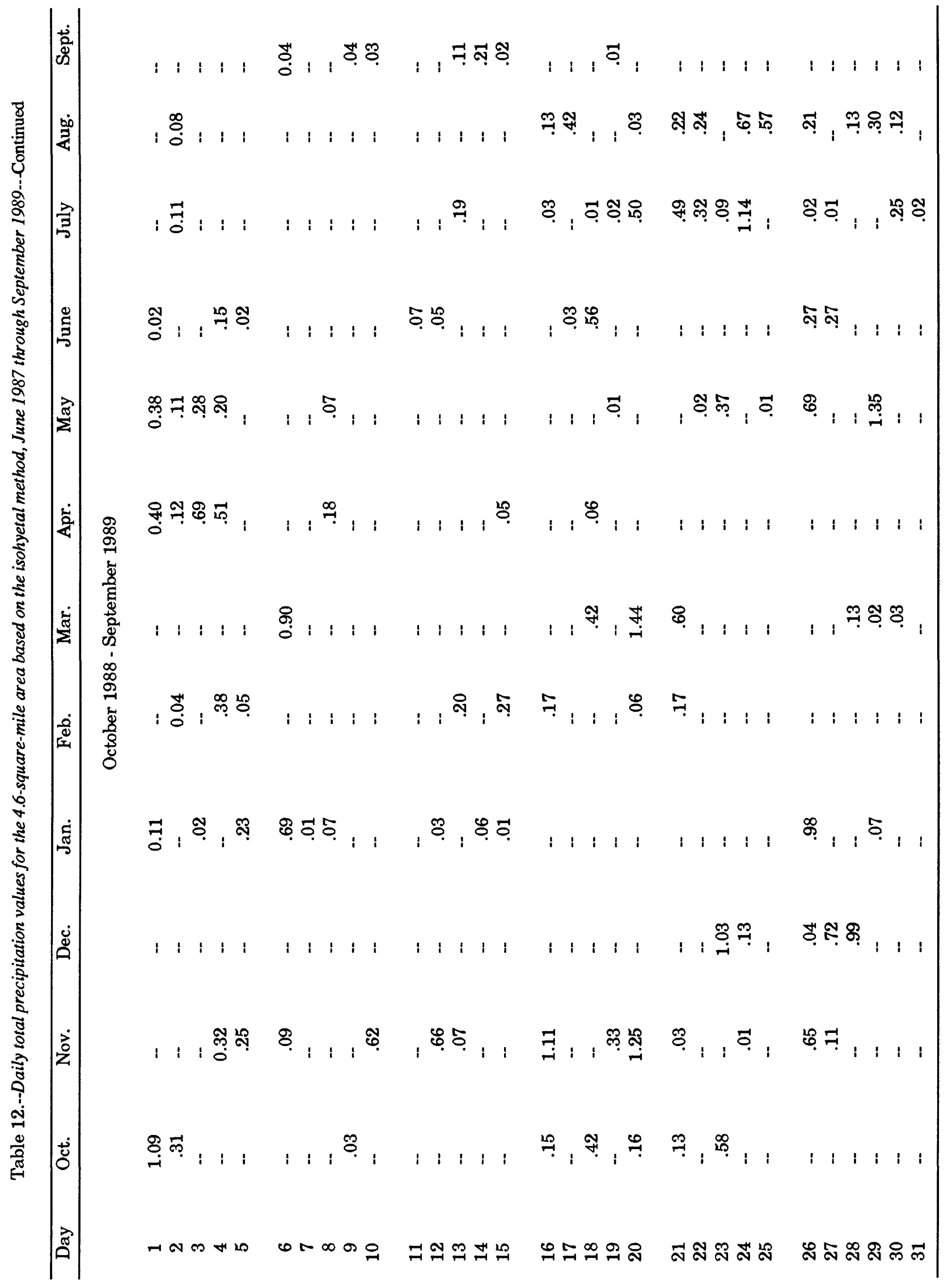




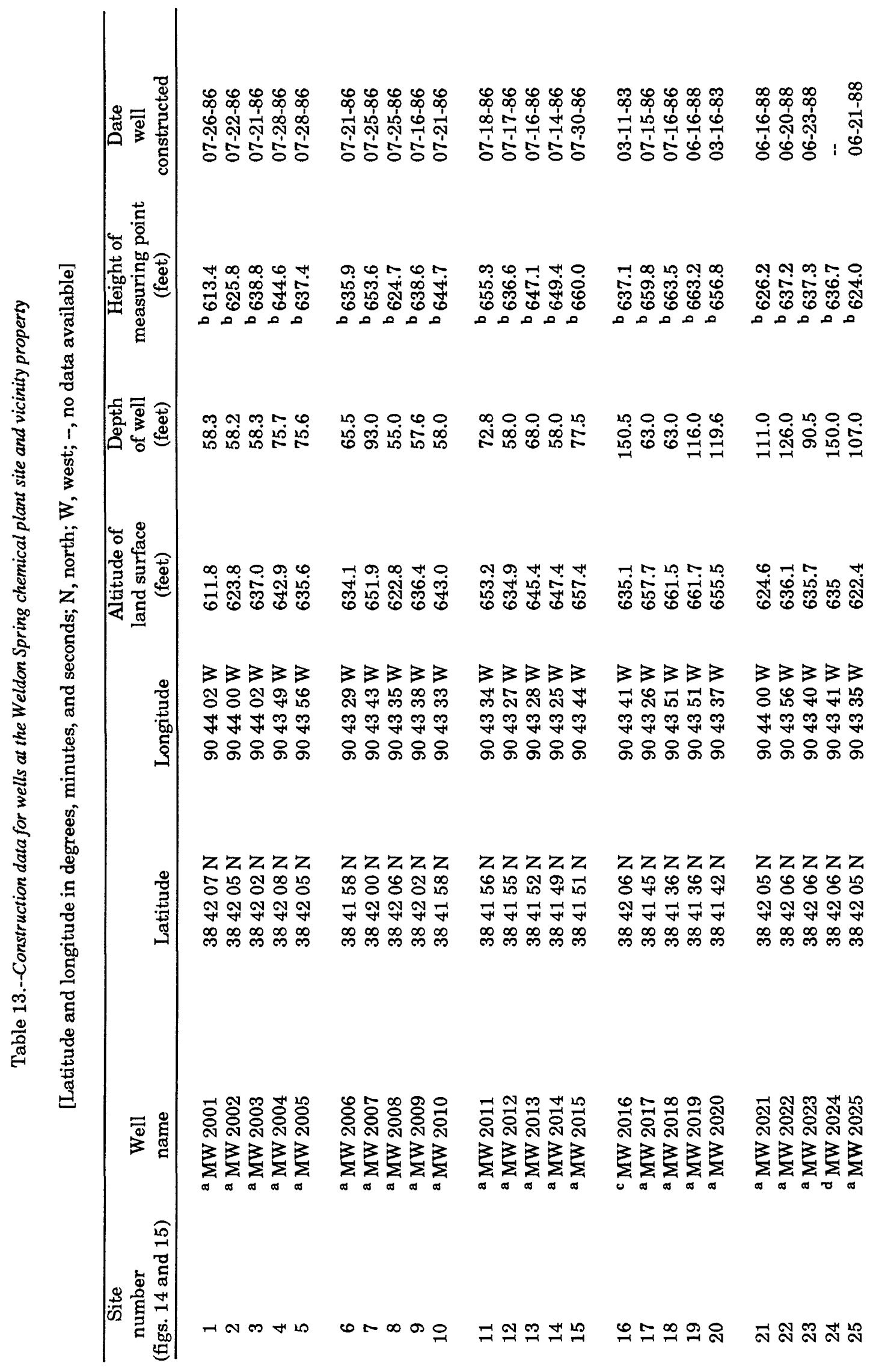




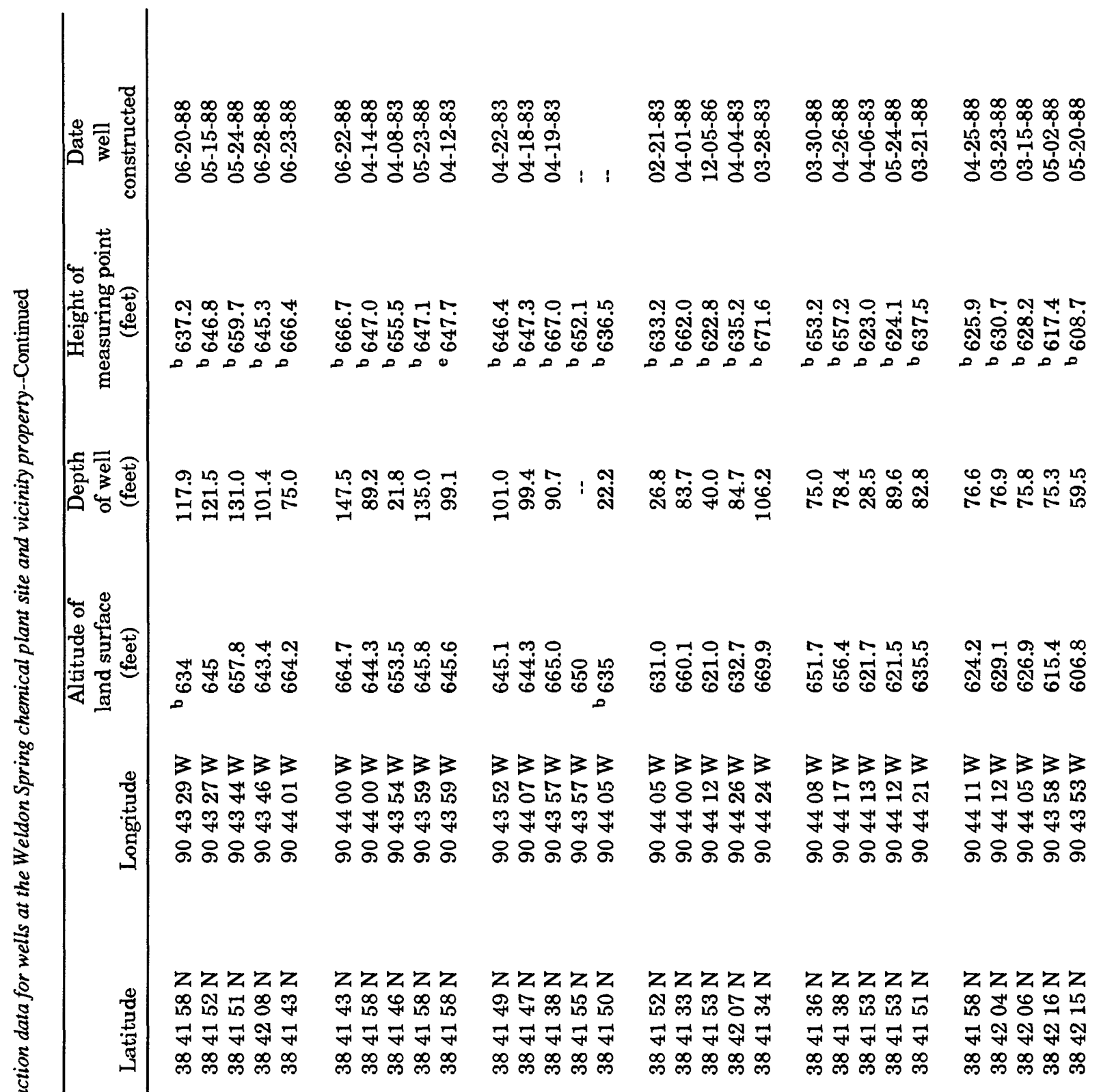

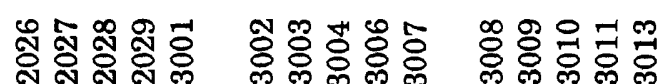

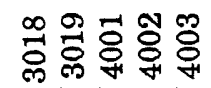

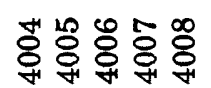

$\sum_{\pi} \sum_{\pi} \sum_{\pi} \sum_{\pi} \sum_{\pi} \sum_{\pi}$

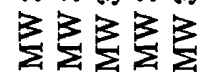

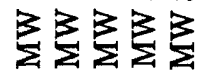

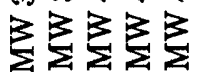

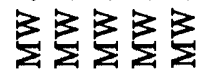

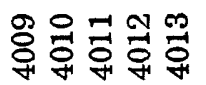

$\sum_{\sigma} \sum_{\pi} \sum_{\sigma} \sum_{\sigma} \sum_{\pi} \sum_{\pi}$

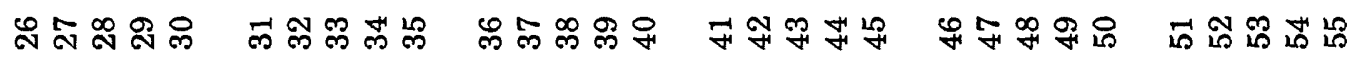




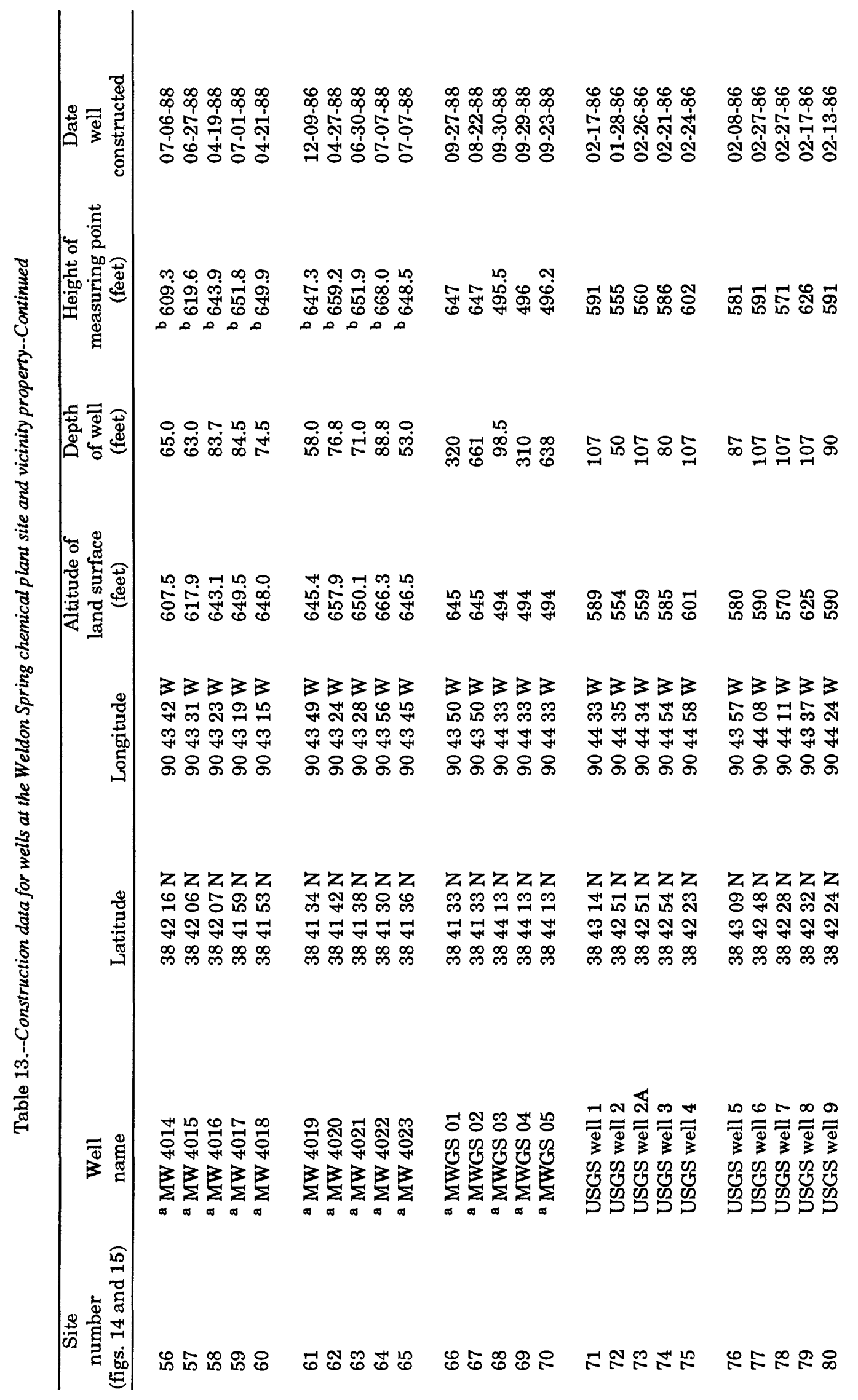




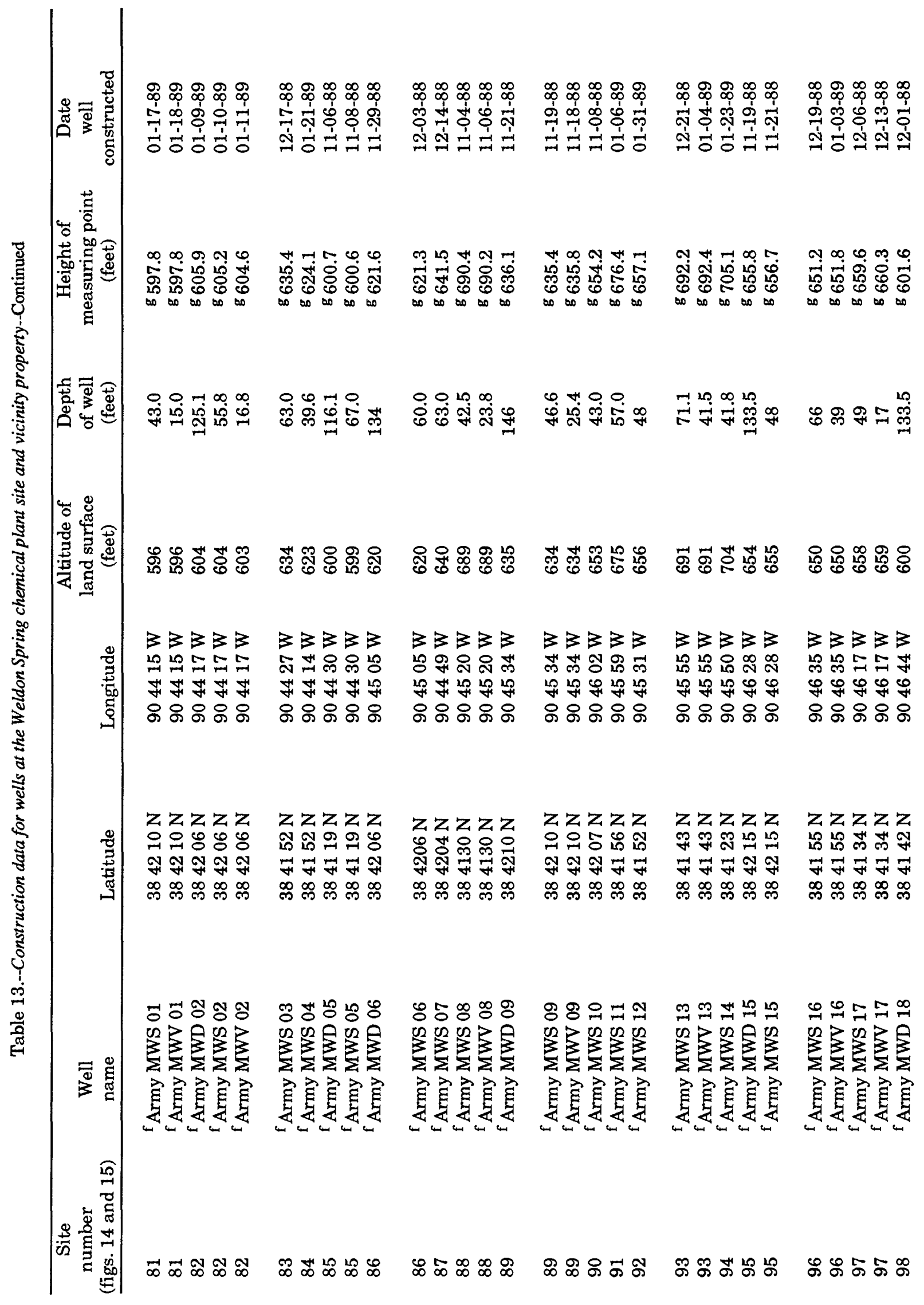




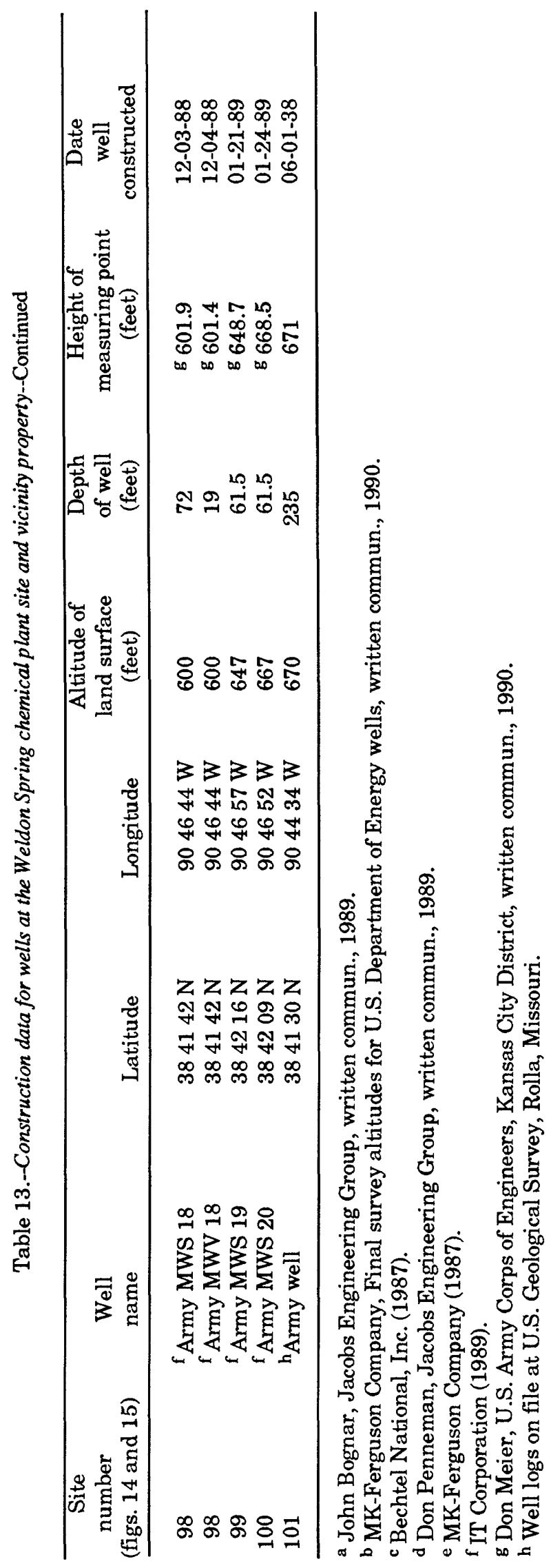




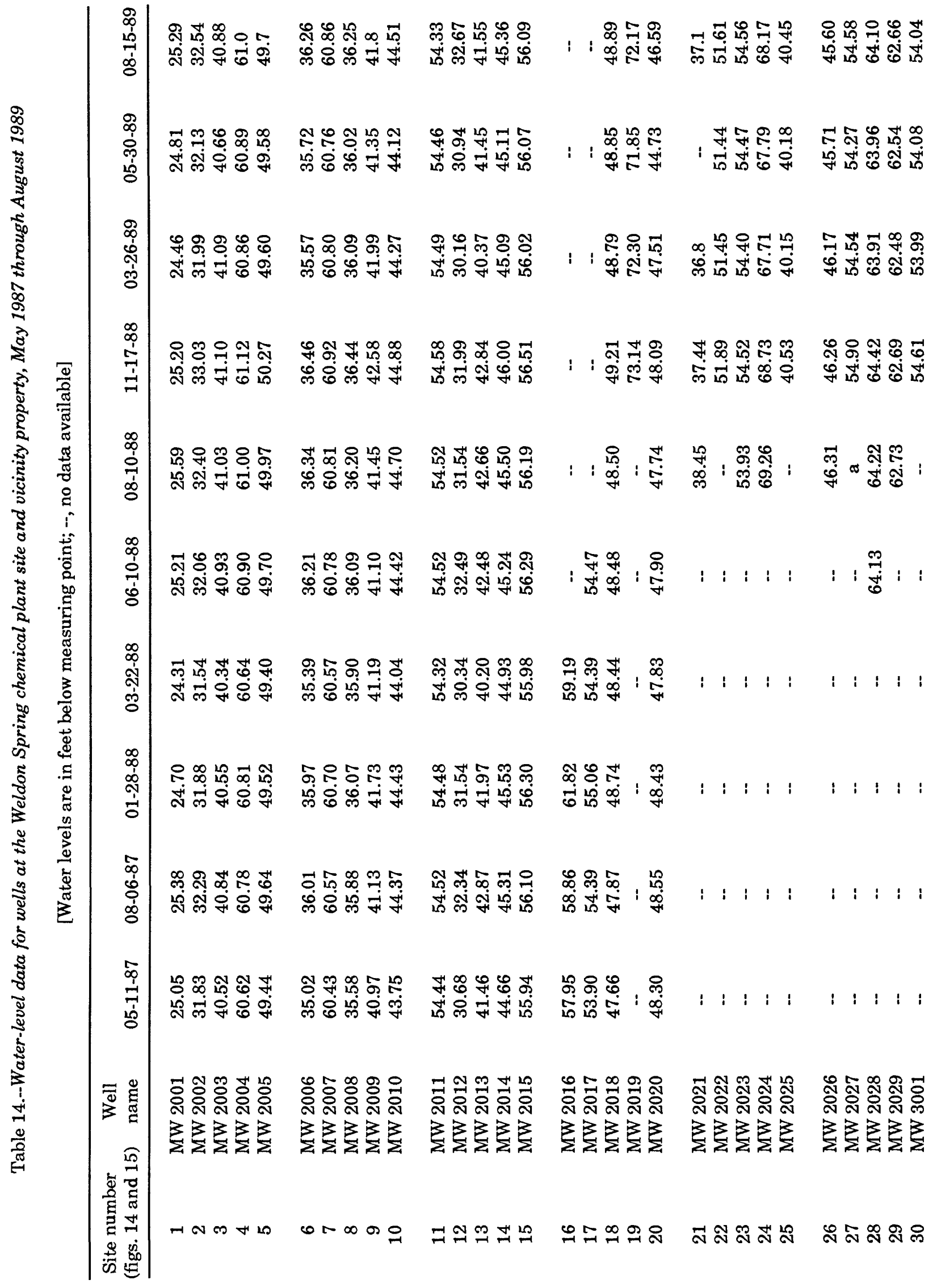




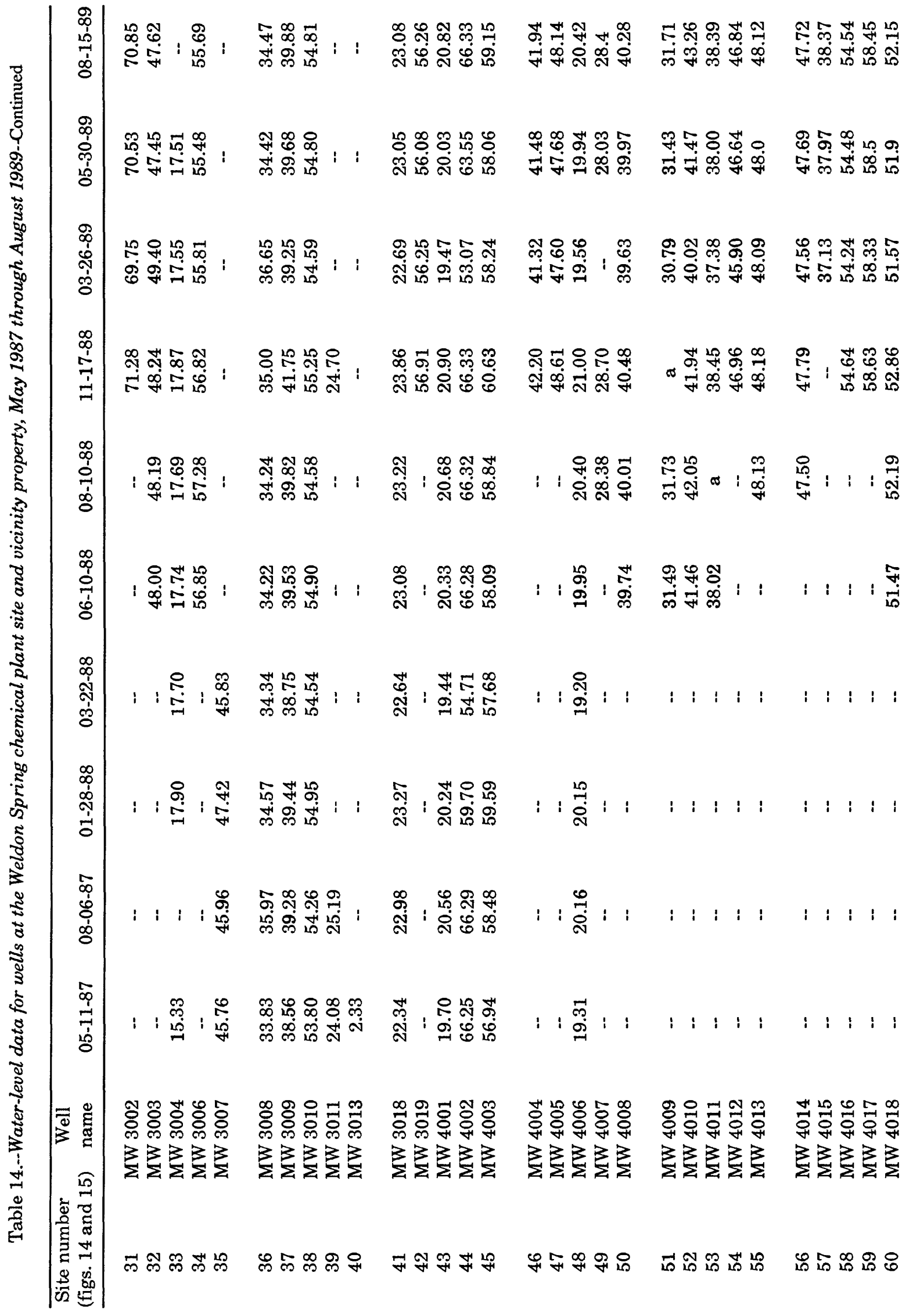




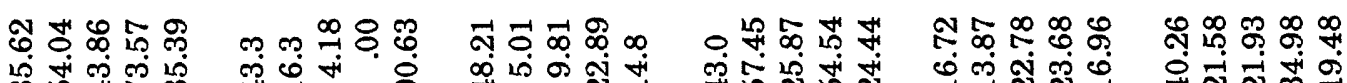

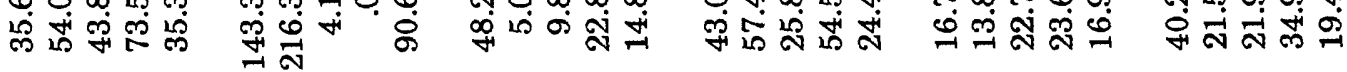

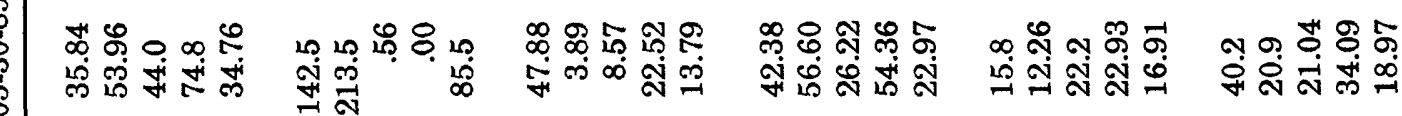

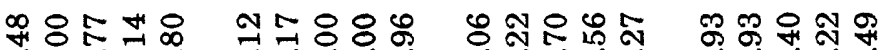

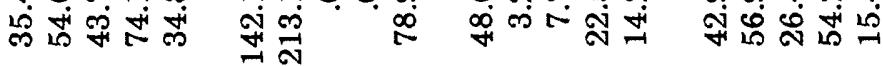

군?유유 웅

ఝำ

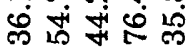

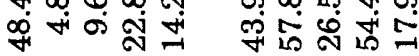

$\infty$

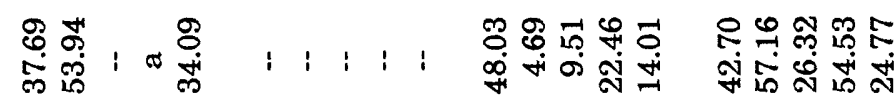

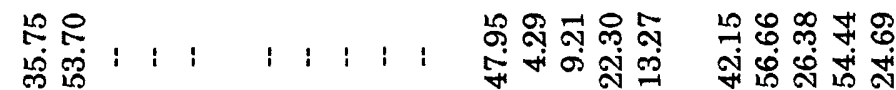

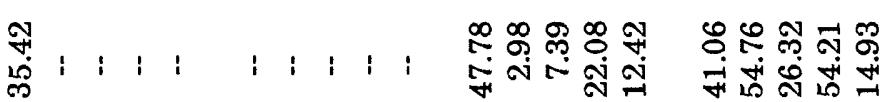

$: 1: 1$

ศุำ 궁ำ

ส

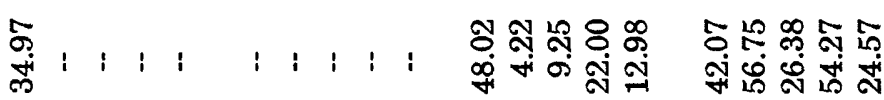

$: \quad: \quad: \quad$

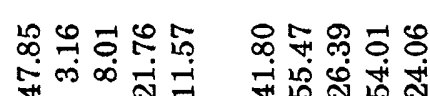

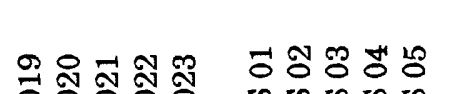

$\rightarrow \infty \int_{0}$

$1005 \infty$

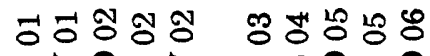

$\overline{\bar{\sigma}} \overline{\bar{\sigma}} \overline{\bar{\sigma}} \overline{\bar{\sigma}} \overline{\bar{\sigma}} \overline{\bar{\sigma}}$

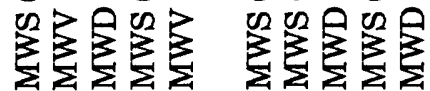

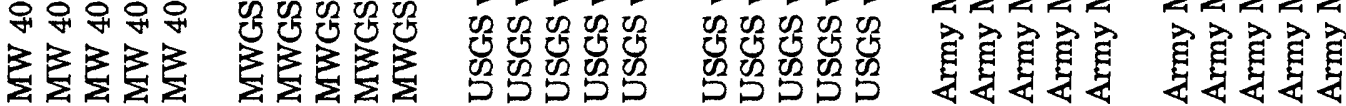

ঢํํㅇํำ 


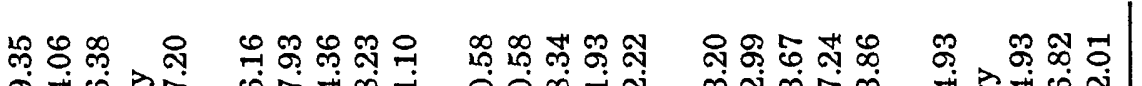

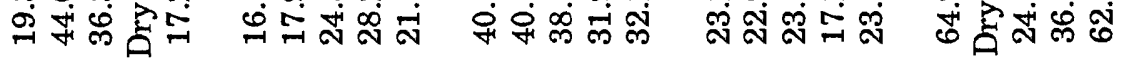

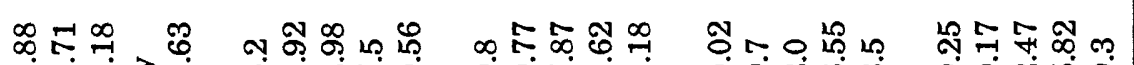

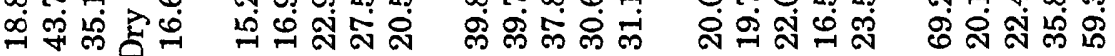

